\title{
Evaluation of Available Saline Water Resources in New Mexico for the Production of Microalgae
}

R. Lansford

J. Hernandez

P. Enis

D. Truby

C. Mapel

August 1990

Prepared under Task No. BF911010

Solar Energy Research Institute

A Division of Midwest Research Institute

1617 Cole Boulevard

Golden, Colorado 80401-3393

Prepared for the

U.S. Department of Energy

Contract No. DE-AC02-83CH10093 


\section{NOTICE}

This report was prepared as an account of work sponsored by an agency of the United States government. Neither the United States government nor any agency thereof, nor any of their employees, makes any warranty, express or implied, or assumes any legal liability or responsibility for the accuracy, completeness, or usefulness of any information, apparatus, product, or process disclosed, or represents that its use would not infringe privately owned rights Reference herein to any specific commercial product, process, or service by trade name, trademark, manufacturer, or otherwise does not necessarily con. stitute or imply its endorsement, recommendation, or favoring by the United States government or any agency thereof. The views and opinions of authors expressed herein do not necessarily state or reflect those of the United States government or any agency thereof.

\section{Printed in the United States of America}

Available from:

National Technical Information Service

U.S. Department of Commerce

5285 Port Royal Road

Springfield, VA 22161

Price: Microfiche A01

Printed Copy A05

Codes are used for pricing all publications. The code is determined by the number of pages in the publication. Information pertaining to the pricing codes can be found in the current issue of the following publications which are generally available in most libraries: Energy Research Abstracts (ERA); Govern. ment Reports Announcements and Index (GRA and I); Scientific and Technical Abstract Reports (STAR); and publication NTIS-PR-360 available from NTIS at the above address. 


\section{SUMMARY}

The major objective of the research was to select potential sites in New Mexico for 1000-ha (2470-acre) microalgae production facilities using saline water resources. The emphasis of the research was twofold.

First, a data base was created following the Solar Energy Research Institute's (SERI) criteria for locating microalgae production facilities in New Mexico. Specific criteria included location, depth to water, aquifer characteristics, saturated thickness of aquifers, salinity, ionic composition and well-yields, growing season, topography, and land ownership.

Second, the data base was digitized for the construction of maps. The desirable water supply for algae culture was limited to moderately or more saline groundwaters ( $3000 \mathrm{mg} / \mathrm{L}$ TDS) because of the demands for the limited supply of better-quality water.

After a review of the 15 billion acre-ft of saline water resources in the state, areas that appeared to generally meet the SERI criteria for site selection were narrowed to the following: the Tularosa Basin in south-central New Mexico, the Estancia Basin in central New Mexico, the San Juan Basin in northwestern New Mexico, the Tucumcari area in Quay County on the east side of the state, the area east of the Pecos River Basin in eastern New Mexico, and the Crow Flats area in southern New Mexico.

A detailed analysis was completed for the six locations. Three basins were eliminated for failing to meet all the criteria developed for the study: Pecos Basin, San Juan Basin, and the Tucumcari area. Of the remaining basins, the Tularosa was judged best suited for a microalgae production facility, Crow Flats the next best, and Estancia the poorest of the three choices because of a short growing season.

The reserves of saline waters ranging from 2.3 million to 5.0 million acre-ft were identified as possible large-scale microalgae production areas in New Mexico. 


\section{TABLE OF CONTENTS}

$\underline{\text { Page }}$

1.0 Introduction $\ldots \ldots \ldots \ldots \ldots \ldots \ldots \ldots \ldots \ldots \ldots \ldots \ldots \ldots \ldots \ldots \ldots \ldots \ldots \ldots \ldots \ldots \ldots$

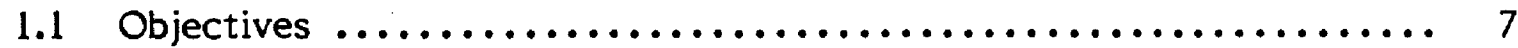

1.2 Literature Review $\ldots \ldots \ldots \ldots \ldots \ldots \ldots \ldots \ldots \ldots \ldots \ldots \ldots \ldots \ldots \ldots \ldots \ldots \ldots$

1.2.1 Microalgae Siting ............................. 7

1.2.2 Agricultural Siting $\ldots \ldots \ldots \ldots \ldots \ldots \ldots \ldots \ldots \ldots \ldots \ldots \ldots \ldots$

1.2 .3 Saline Water Resources ....................... 8

1.2.3.1 Rio Grande Basin ...................... 8

1.2.3.2 Tularosa Basin ....................... 8

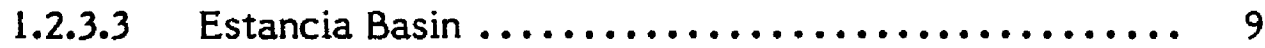

1.2.3.4 Salt Basin ........................... 9

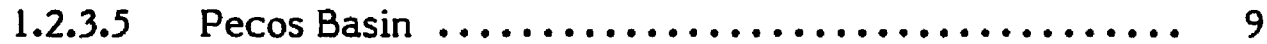

1.2.3.6 Tucumcari Area ........................ 10

1.2.3.7 San Juan Basin ....................... 10

1.2 .3 .8 Ogallala Aquifer $\ldots \ldots \ldots \ldots \ldots \ldots \ldots \ldots \ldots \ldots \ldots \ldots$

2.0 Methodology $\ldots \ldots \ldots \ldots \ldots \ldots \ldots \ldots \ldots \ldots \ldots \ldots \ldots \ldots \ldots \ldots \ldots \ldots \ldots \ldots \ldots$

2.1 Task $1 \ldots \ldots \ldots \ldots \ldots \ldots \ldots \ldots \ldots \ldots \ldots \ldots \ldots \ldots \ldots \ldots \ldots \ldots \ldots \ldots \ldots \ldots$

2.2 Task $2 \ldots \ldots \ldots \ldots \ldots \ldots \ldots \ldots \ldots \ldots \ldots \ldots \ldots \ldots \ldots \ldots \ldots \ldots \ldots \ldots \ldots \ldots \ldots \ldots 11$

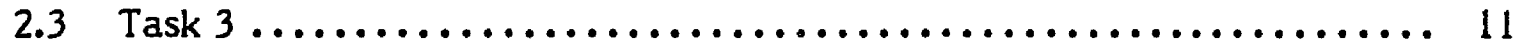

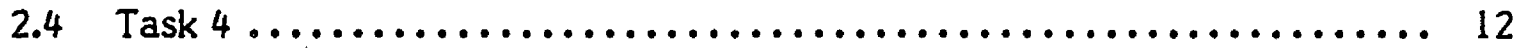

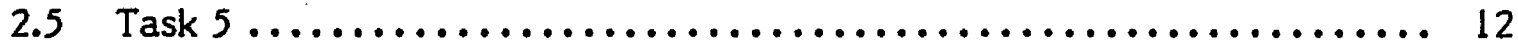

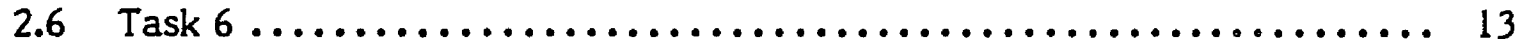

2.7 Task $7 \ldots \ldots \ldots \ldots \ldots \ldots \ldots \ldots \ldots \ldots \ldots \ldots \ldots \ldots \ldots \ldots \ldots \ldots \ldots \ldots \ldots \ldots \ldots \ldots \ldots$

2.8 Task $8 \ldots \ldots \ldots \ldots \ldots \ldots \ldots \ldots \ldots \ldots \ldots \ldots \ldots \ldots \ldots \ldots \ldots \ldots \ldots \ldots \ldots \ldots$

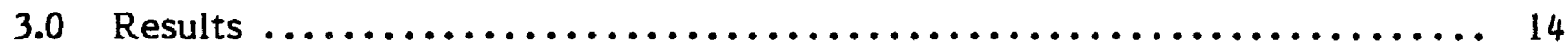

3.1 Climate and Surface Characteristics ..................... 14

3.2 Groundwater Quality ................................... 14

3.3 Unappropriated Saline Water Resources ..................... 14

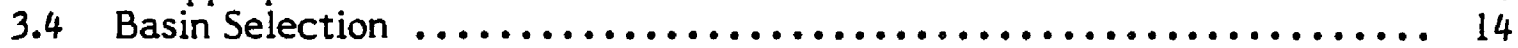

3.5 The Tularosa Basin $\ldots \ldots \ldots \ldots \ldots \ldots \ldots \ldots \ldots \ldots \ldots \ldots \ldots \ldots \ldots \ldots \ldots \ldots \ldots$

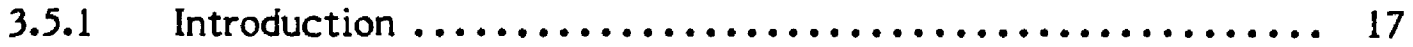

3.5.2 Setting and Climatic Characteristics ................ 17

$3.5 .3 \quad$ Study Area ................................. 19 3.5.3.1 Land Ownership and Slope ................ 19

3.5.3.2 Water Resources ....................... 23

3.5.3.3 Groundwater Quality ................... 23

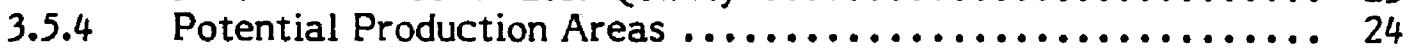

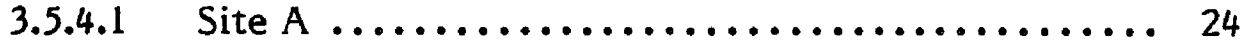

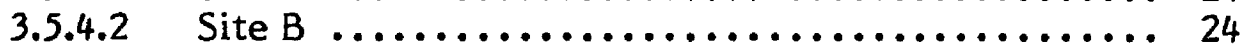

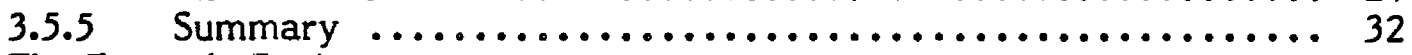

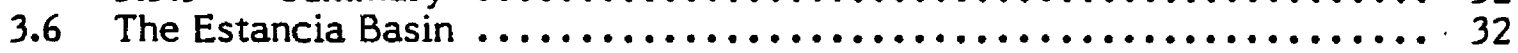

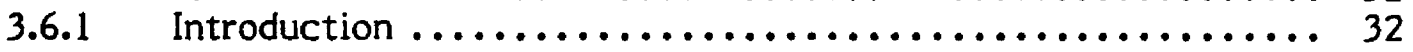

3.6.2 Setting and Climatic Characteristics............... 32

3.6.3 Study Area ............................... 35 
TABLE OF CONTENTS (Concluded)

Page

3.6.3.1 Land Ownership and Slope $\ldots \ldots \ldots \ldots \ldots \ldots \ldots \ldots . . . \ldots$

3.6.3.2 Water Resources ....................... 35

3.6.3.3 Groundwater Quality ..................... 40

3.6.4 Potential Production Areas .......................... 40

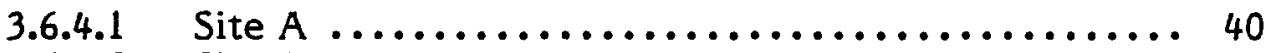

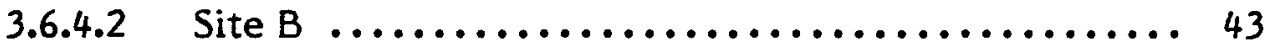

3.6.5 Summary $\ldots \ldots \ldots \ldots \ldots \ldots \ldots \ldots \ldots \ldots \ldots \ldots \ldots \ldots \ldots \ldots, 43$

3.7 The Crow Flats Area $\ldots \ldots \ldots \ldots \ldots \ldots \ldots \ldots \ldots \ldots \ldots \ldots \ldots \ldots \ldots \ldots, 44$

3.7.1 Introduction $\ldots \ldots \ldots \ldots \ldots \ldots \ldots \ldots \ldots \ldots \ldots \ldots \ldots \ldots \ldots \ldots \ldots \ldots \ldots \ldots, 44$

3.7.2 Setting and Climatic Characteristics................... 44

3.7 .3 Study Area $\ldots \ldots \ldots \ldots \ldots \ldots \ldots \ldots \ldots \ldots \ldots \ldots \ldots \ldots \ldots, 44$

3.7.3.1 Land Ownership and Slope ................... 44

3.7.3.2 Groundwater Resources ................... 50

3.7.3.3 Groundwater Quality $\ldots \ldots \ldots \ldots \ldots \ldots \ldots \ldots \ldots \ldots, 50$

3.7.4 Potential Production Areas ......................... 50

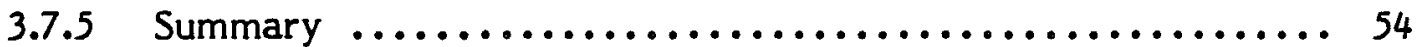

3.8 The Tucumcari Area $\ldots \ldots \ldots \ldots \ldots \ldots \ldots \ldots \ldots \ldots \ldots \ldots \ldots \ldots \ldots, 54$

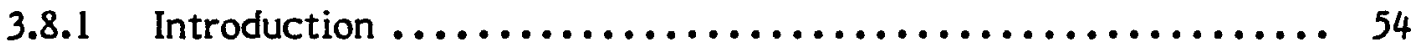

3.8.2 Setting and Climatic Characteristics.................. 56

3.8.3 Area Geology and Aquifer Recharge ................. 56

3.8.4 Effect of Irrigation on Area Recharge................ 56

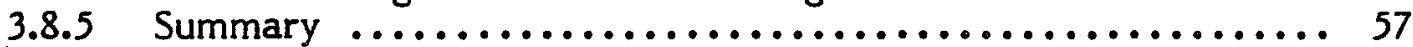

3.9 The Pecos Basin $. \ldots \ldots \ldots \ldots \ldots \ldots \ldots \ldots \ldots \ldots \ldots \ldots \ldots \ldots \ldots, 58$

3.9.1 Setting and Climatic Characteristics................. 58

3.9.2 Groundwater Resources ......................... 58

3.9.3 Groundwater Quality ......................... 58

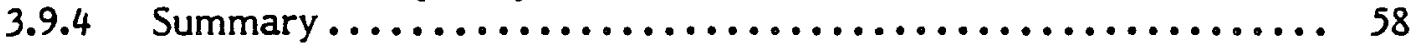

3.10 The San Juan Basin ................................6 60

3.10.1 Setting and Climatic Characteristics ................. 60

3.10 .2 Groundwater Resources $\ldots \ldots \ldots \ldots \ldots \ldots \ldots \ldots \ldots \ldots \ldots, 60$

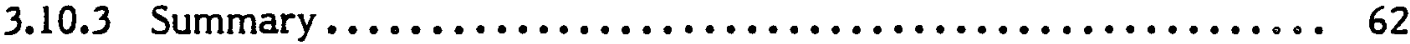

4.0 Summary and Conclusions $\ldots \ldots \ldots \ldots \ldots \ldots \ldots \ldots \ldots \ldots \ldots \ldots \ldots \ldots, 63$

4.1 Objectives and Methodology $\ldots \ldots \ldots \ldots \ldots \ldots \ldots \ldots \ldots \ldots \ldots \ldots, 63$

4.2 Basins Reviewed $. \ldots \ldots \ldots \ldots \ldots \ldots \ldots \ldots \ldots \ldots \ldots \ldots \ldots \ldots \ldots, 63$

4.2.1 Tularosa Basin $\ldots \ldots \ldots \ldots \ldots \ldots \ldots \ldots \ldots \ldots \ldots \ldots \ldots \ldots, 63$

4.2.2 Estancia Basin ................................6.63 63

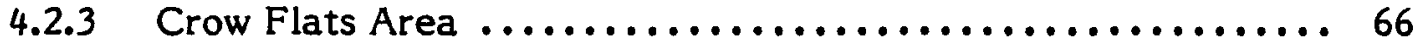

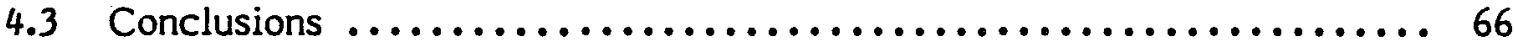

4.3.1 Additional Study Areas......................... 66

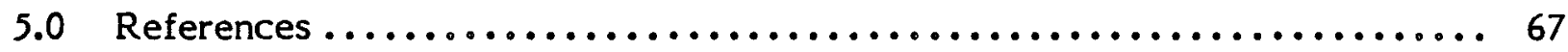

Appendix A............................................... 70

Appendix B $\ldots \ldots \ldots \ldots \ldots \ldots \ldots \ldots \ldots \ldots \ldots \ldots \ldots \ldots \ldots \ldots \ldots \ldots \ldots \ldots, 76$ 


\section{LIST OF FIGURES}

Page

1-1 General occurrence of saline groundwater in New Mexico $\ldots \ldots \ldots \ldots \ldots \ldots, 2$

1-2 Estimated potential yield of wells in New Mexico $\ldots \ldots \ldots \ldots \ldots \ldots \ldots . ., 3$

1-3 Estimated thickness of aquifers with slightly saline groundwater in

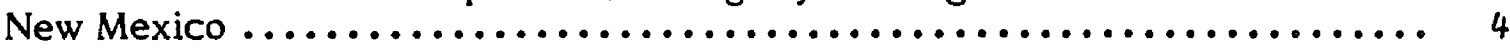

1-4 Estimated thickness of aquifers with moderately saline groundwater

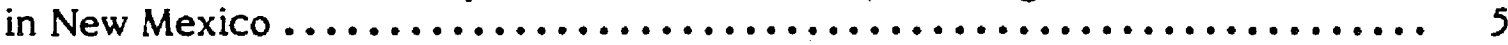

1-5 Estimated thickness of aquifers with very saline groundwater in

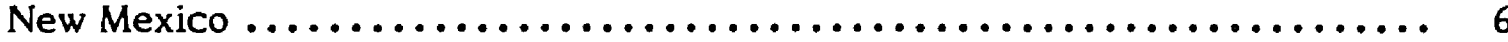

3-1 Microalgae study areas in New Mexico $\ldots \ldots \ldots \ldots \ldots \ldots \ldots \ldots \ldots \ldots \ldots .16$

3-2 Location of the Tularosa Basin, New Mexico $\ldots \ldots \ldots \ldots \ldots \ldots \ldots \ldots \ldots . . .18$

3-3 Study area and potential production areas in the Tularosa Basin,

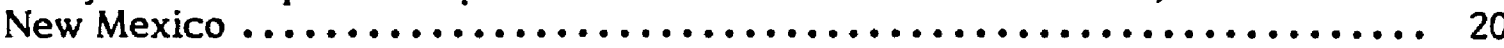

3-4 Tularosa Basin, places with land slopes that exceed $2 \%$ within the study area and potential production areas $\ldots \ldots \ldots \ldots \ldots \ldots \ldots \ldots \ldots, 21$

3-5 Tularosa Basin, land ownership within the study area and potential production areas

3-6 Tularosa Basin, saturated thickness (in $\mathrm{ft}$ ) of the moderately saline water zones (3-10 g/L TDS) within the study area

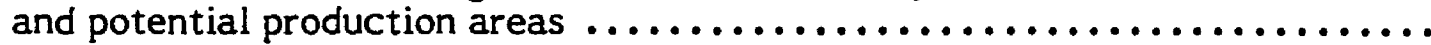

3-7 Tularosa Basin, saturated thickness (in $\mathrm{ft}$ ) of fresh-water zones within the study area and potential production areas $\ldots \ldots \ldots \ldots \ldots \ldots 26$

3-8 Tularosa Basin, saturated thickness (in $\mathrm{ft}$ ) of slightly saline water zones (1-3 g/L TDS) within the study area and potential

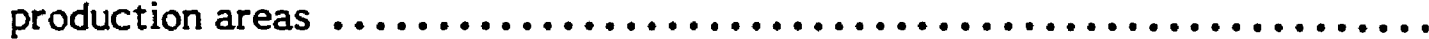

3-9 Tularosa Basin, saturated thickness (in $\mathrm{ft}$ ) of the very saline water zones (10-35 g/L TDS) within the study area and potential production areas

3-10 Tularosa Basin, potential well-yields (in gpm) within the study area and potential production areas. 


\section{LIST OF FIGURES (Continued)}

Page

3-11 Tularosa Basin, depth to groundwater (in $\mathrm{ft}$ ) within the study area

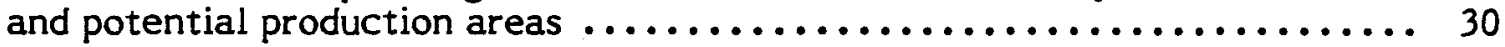

3-12 Location of the Estancia Basin, New Mexico ................... 33

3-13 Study area and potential production areas in the Estancia Basin,

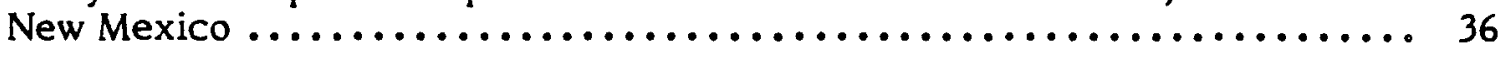

3-14 Estancia Basin, land ownership within the study area and potential production areas .

3-15 Estancia Basin, places with land slopes that exceed $2 \%$ within the study area and potential production areas $\ldots \ldots \ldots \ldots \ldots \ldots \ldots \ldots \ldots . \ldots . \ldots . \ldots$

3-16 Estancia Basin, geologic zones within the study area and potential

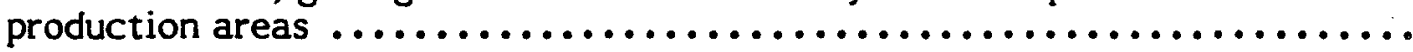

3-17 Estancia Basin, water quality (specific conductance in micromhos per $\mathrm{cm}$ at $25^{\circ} \mathrm{C}$ ) within the study area and potential production areas $\ldots \ldots \ldots \ldots .41$

3-18 Location of the Salt Basin and the Crow Flats Area, New Mexico ........ 45

3-19 Study and potential production areas in the Crow Flats Area, New Mexico ....................................... 47

3-20 Crow Flats Area, places with land slopes that exceed $2 \%$ within the study area and potential production areas $\ldots \ldots \ldots \ldots \ldots \ldots \ldots \ldots \ldots \ldots, 48$

3-21 Crow Flats Area, land ownership within the study area and

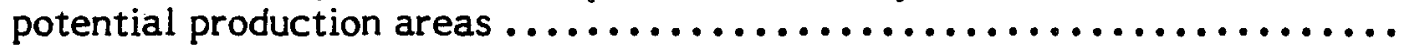

3-22 Crow Flats Area, depth to groundwater ( $\mathrm{ft}$ ) within the study area and

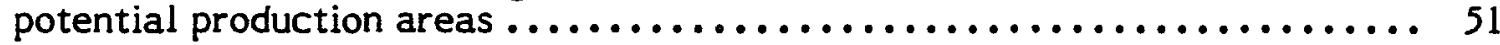

3-23 Crow Flats Area, water quality (specific conductance in micromhos per $\mathrm{cm}$ at $25^{\circ} \mathrm{C}$ ) within the study area and potential production areas $\ldots \ldots \ldots \ldots . .52$

3-24 Location of the Tucumcari Area, New Mexico .................. 55

3-25 Location of the Pecos Basin, New Mexico ................... 59

3-26 Location of the San Juan Basin, New Mexico ................... 61

4-1 Potential microalgae production areas in the state of New Mexico ........ 64

A-1 Median length of growing season (in days, $32^{\circ} \mathrm{F}$ base temperature) showing study areas in New Mexico 


\section{LIST OF FIGURES (Concluded)}

Page

A-2 Annual mean daily temperature (in ${ }^{\circ} \mathrm{F}$ ) showing study areas in

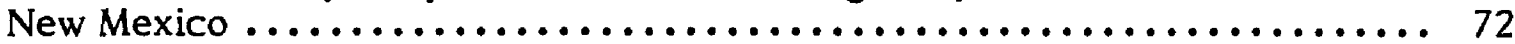

A-3 Normal annual precipitation (in in.) showing study areas in

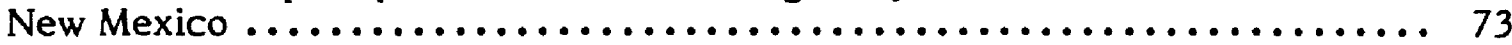

A-4 Annual mean daily solar radiation (in $B t u / \mathrm{ft}^{2} / \mathrm{d}$ ) showing study areas in New Mexico .................................... 74

A-5 Gross annual lake evaporation (in in.) showing study areas in

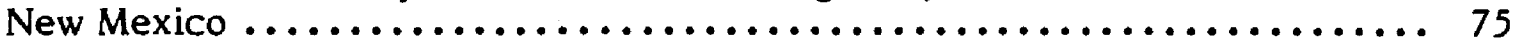

B-1 Diagram showing systems of numbering wells $\ldots \ldots \ldots \ldots \ldots \ldots \ldots \ldots \ldots, 77$ 


\section{LIST OF TABLES}

3-1 Water Available for New Appropriations in Declared Underground

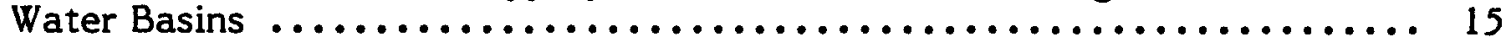

3-2 Selected Climatic Data for Stations within the Tularosa Basin,

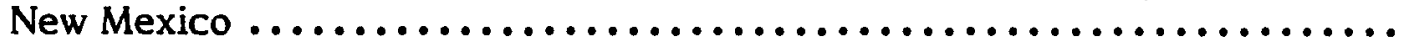

3-3 Site and Groundwater Characteristics for Potential Production Areas in Tularosa Basin, New Mexico ........................... 31

3-4 Selected Climatic Data for Stations within the Estancia Basin, New Mexico $. \ldots \ldots \ldots \ldots \ldots \ldots \ldots \ldots \ldots \ldots \ldots \ldots \ldots \ldots \ldots, 34$

3-5 Site and Groundwater Characteristics for Potential Production Areas in Estancia Basin, New Mexico

3-6 Selected Climatic Data for Stations within the Crow Flats Basin, New Mexico .......................................... 46

3-7 Site and Groundwater Characteristics for Potential Production Areas in Crow Flats Basin, New Mexico ..................... 53

3-8 Selected Climatic Data for Stations within the Tucumcari Basin, New Mexico

3-9 Selected Climatic Data for Stations in Potential Production Areas in the Pecos Basin, New Mexico ........................ 60

3-10 Selected Climatic Data for Stations in Potential Production Areas in the San Juan Basin, New Mexico .....................

4-1 Qualitative Summary of Chosen Sites and Specific Criteria Used in Selection of Areas Suitable for Microalgae Production ............... 65

B-1 Chemical Analyses of Water from Wells in the Tularosa Basin .......... 78

B-2 Chemical Analyses of Water from Wells and Springs in the Estancia Basin ....................................... 82

B-3 Chemical Analyses of Water from Wells in the Crow Flats Basin ........ 83 


\subsection{INTRODUCTION}

This report contributes to compiling an inventory of saline water resources in New Mexico and screening them for suitability as locations for large-scale microalgae production facilities. Production of microalgae could provide a renewable source of fuel, chemicals, and food, and could also use the state's unused saline water resources to increase economic activity.

Approximately $25 \%$ of the estimated 20 billion acre- $\mathrm{ft}$ of groundwater reserves in New Mexico is classified as fresh or slightly saline. The remaining 15 billion acre-ft of unused water is characterized as moderately saline, very saline, or brine (Bureau of Reclamation 1976). The locations of the state's groundwater reserves are relatively well known (Figure 1-1), but the magnitude of these resources and aquifer characteristics has not been rigorously assessed on a statewide basis.

The recoverability of these saline groundwater reserves is also not well known because little effort has been made to use these aquifers. The Bureau of Reclamation (1976), in cooperation with the New Mexico State Engineers' Office, published general maps for potential well-yields and average aquifer thicknesses of the different classes of saline waters (Figures 1-2, 1-3, 1-4, and 1-5) in New Mexico Water Resources: Assessment for Planning Purposes.

Average well-yields across the state vary from less than 25 to more than $500 \mathrm{gpm}$ (Figure 1-2). The lower potential well-yields cover a large area in eastern and central New Mexico. The highest potential well-yields are typically associated with alluvial valley fills in or adjacent to river basins and range as high as $1500 \mathrm{gpm}$.

The aquifers with the greatest potential quantity of slightly saline waters (1000 to $3000 \mathrm{mg} / \mathrm{L}$ total dissolved solids [TDS]) are located in the Middle Rio Grande Basin (Figure 1-3). However, the saline waters lie at great depths below fresh water in the area. The second largest quantity of slightly saline water is located in northwestern New Mexico with aquifer thicknesses between 2000 and $4000 \mathrm{ft}$. Again, these saline waters are deep, and potential well-yields are low.

The moderately saline water resources ( 3000 to $10,000 \mathrm{mg} / \mathrm{L}$ TDS) with the greatest aquifer thicknesses are in the same general areas as the slightly saline water resources (the Middle Rio Grande Basin and northwestern New Mexico) (Figure 1-4). The moderately saline waters generally lie below the slightly saline water resources in these regions.

The very saline water resources $(10,000$ to $35,000 \mathrm{mg} / \mathrm{L}$ TDS) are shown in Figure 1-5. The area in Sierra and Socorro counties with the largest aquifer thicknesses (more than $6000 \mathrm{ft}$ thick) is overlaid with slightly and moderately saline water resources. These very saline water resources are generally more than $2000 \mathrm{ft}$ deep. Areas with aquifer thickness between 4000 and $6000 \mathrm{ft}$ are generally deep, with the exception of a small area in the Estancia Valley. Other aquifers of lesser thicknesses are located in New Mexico at estimated great depths.

Large areas in the state are still open to the drilling of wells for new production without requiring prior permission from the New Mexico state engineer to drill and to use water for beneficial purposes. These are the undeclared basins where the available groundwater supply is poorly known but where it is unlikely that major new reserves will be discovered. 


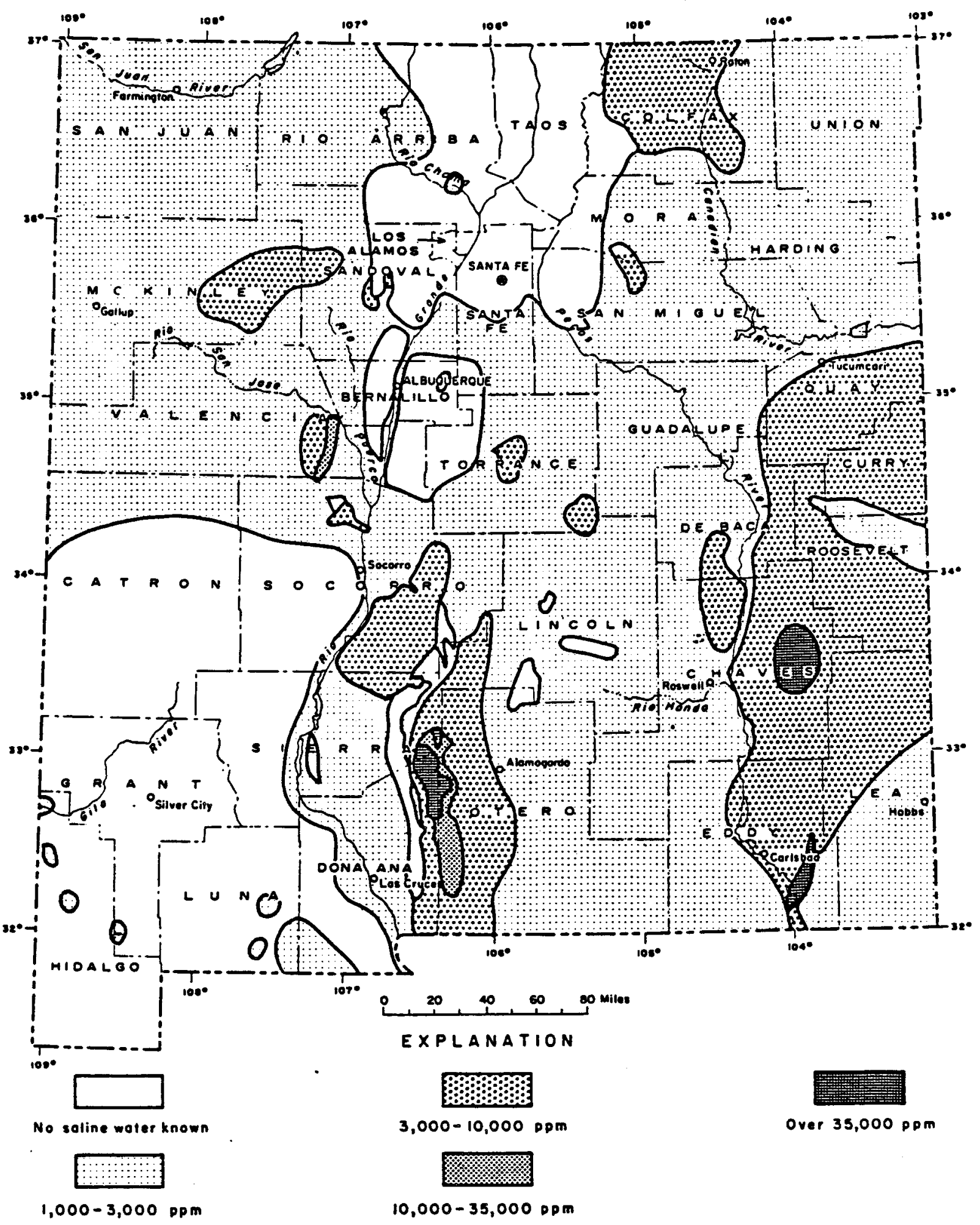

Figure 1-1. General occurrence of saline groundwater in New Mexico Source: Bureau of Reclamation 1976. 


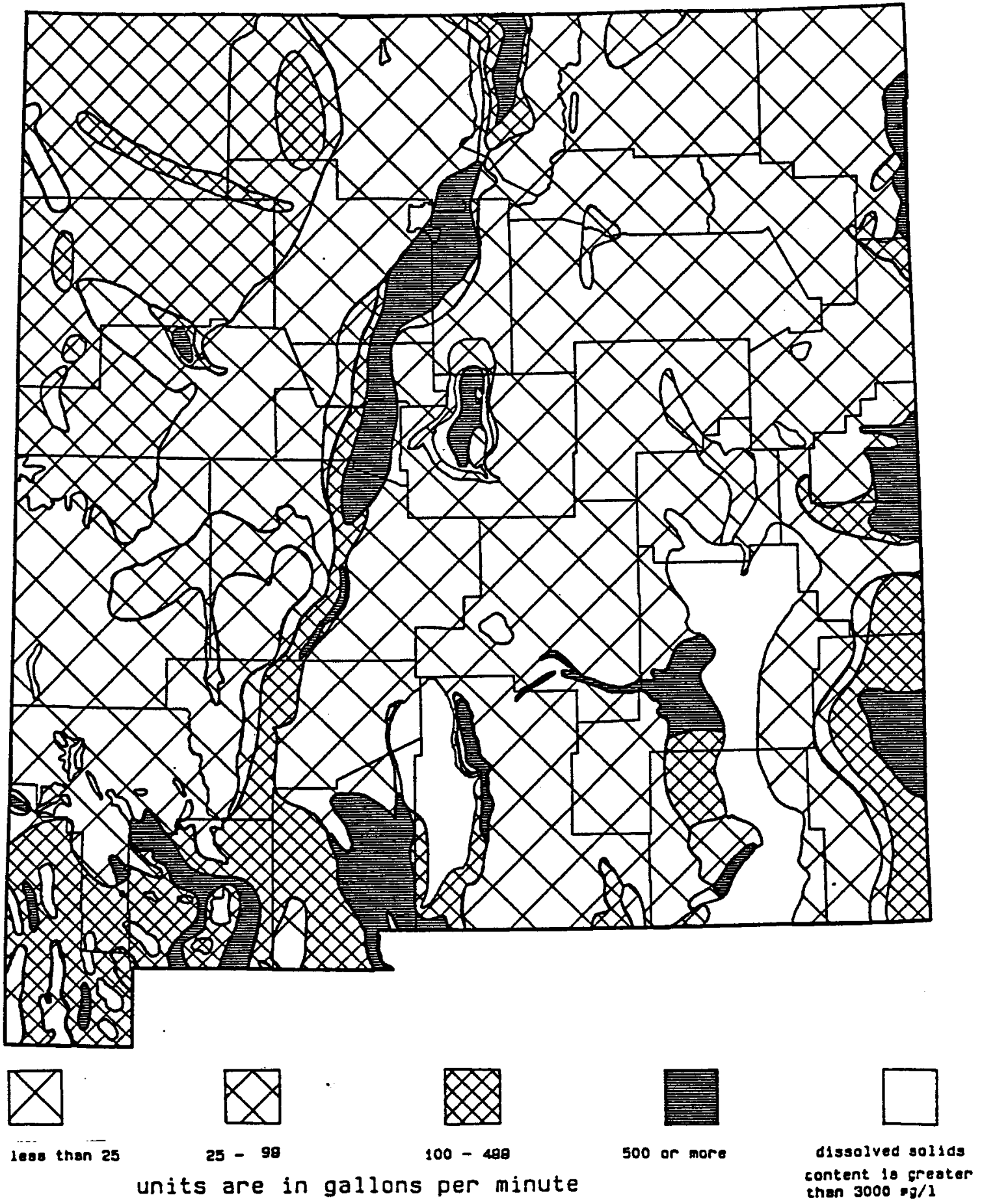

Figure 1-2. Estimated potential yield of wells in New Mexico Source: Bureau of Reclamation 1976. 


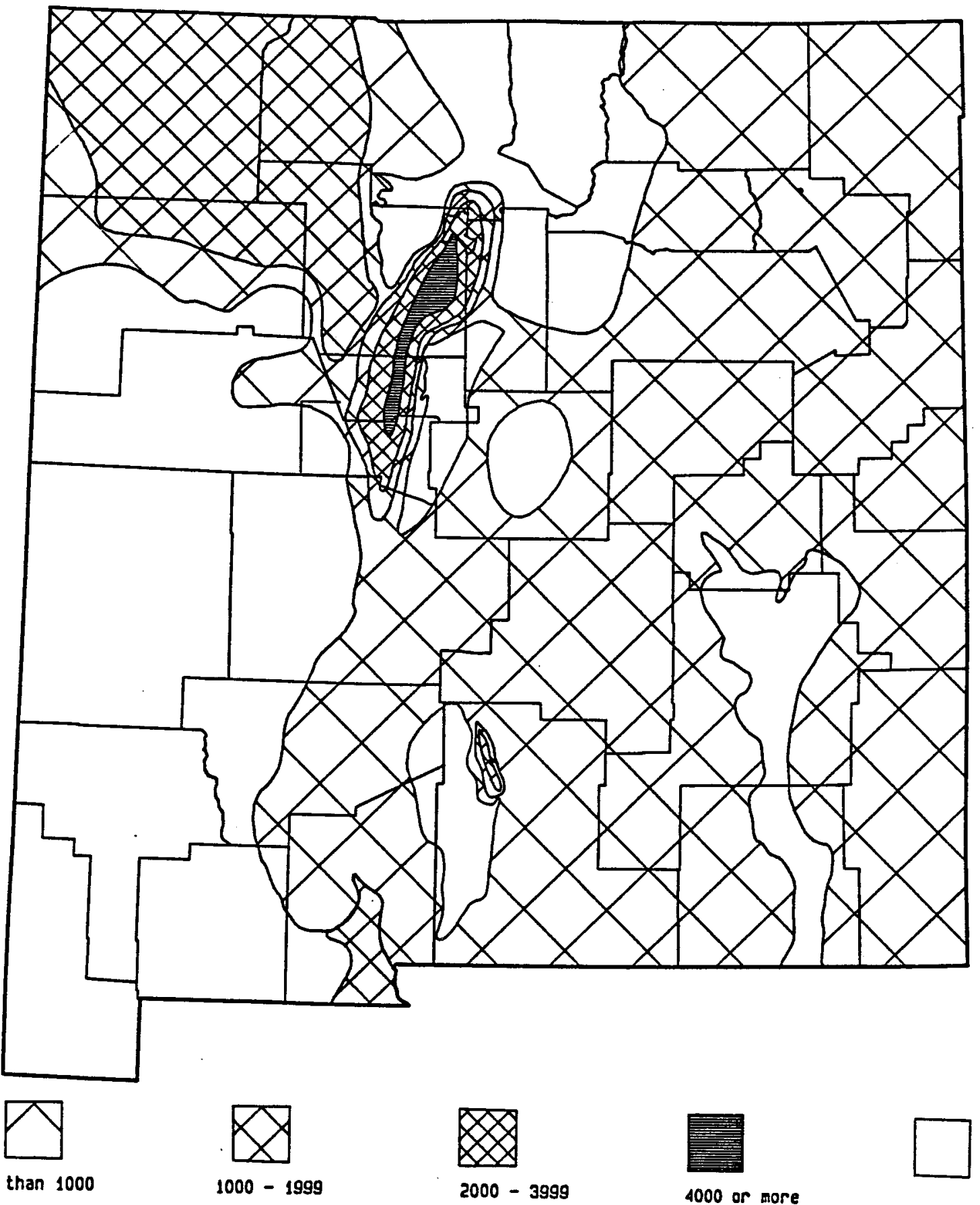

units are in feet

Figure 1-3. Estimated thickness of aquifers with slightly saline groundwater in New Mexico

Source: Bureau of Reclamation 1976 


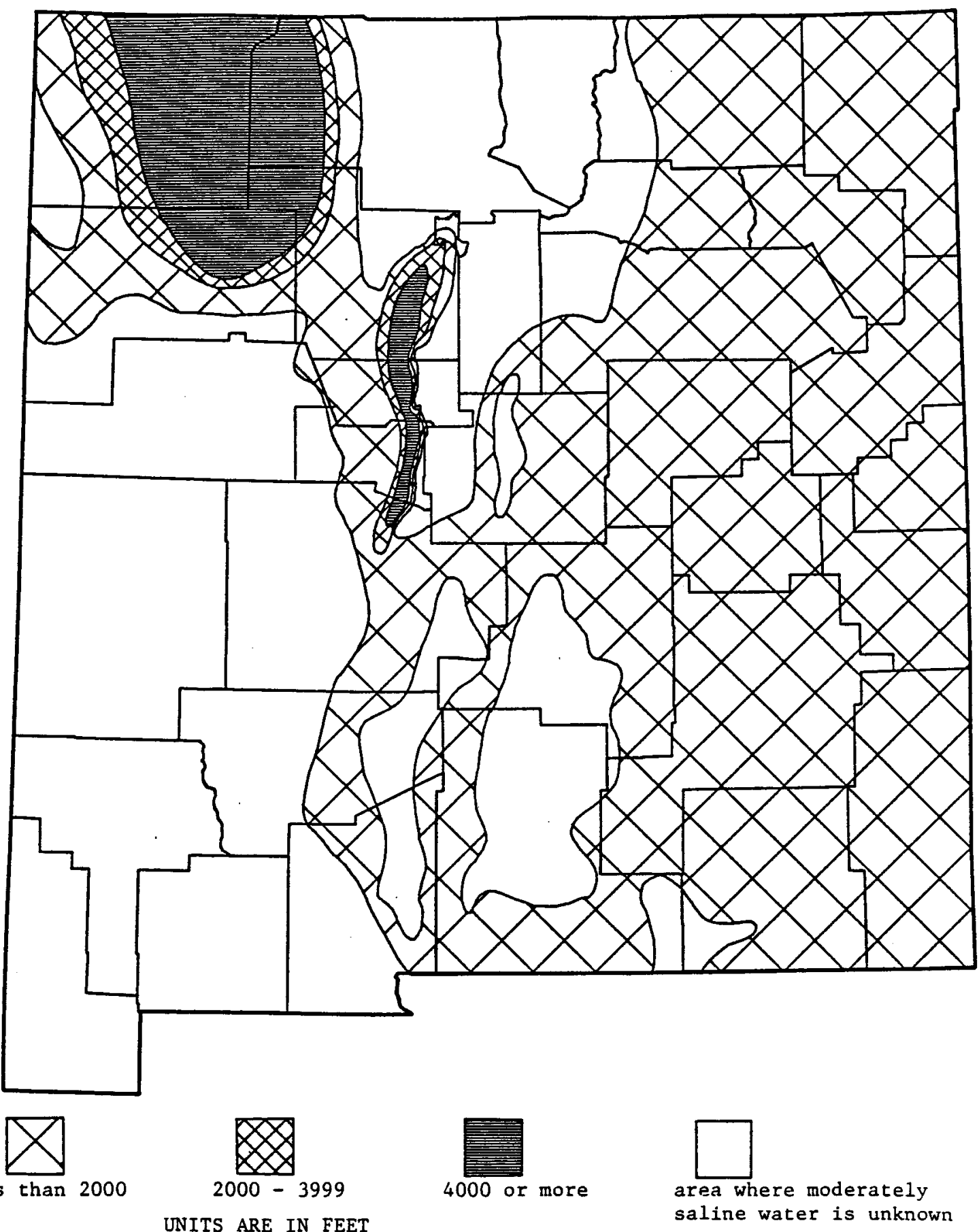

Figure 1-4. Estimated thickness of aquifers with moderately saline groundwater in New Mexico

Source: Bureau of Reclamation 1976 


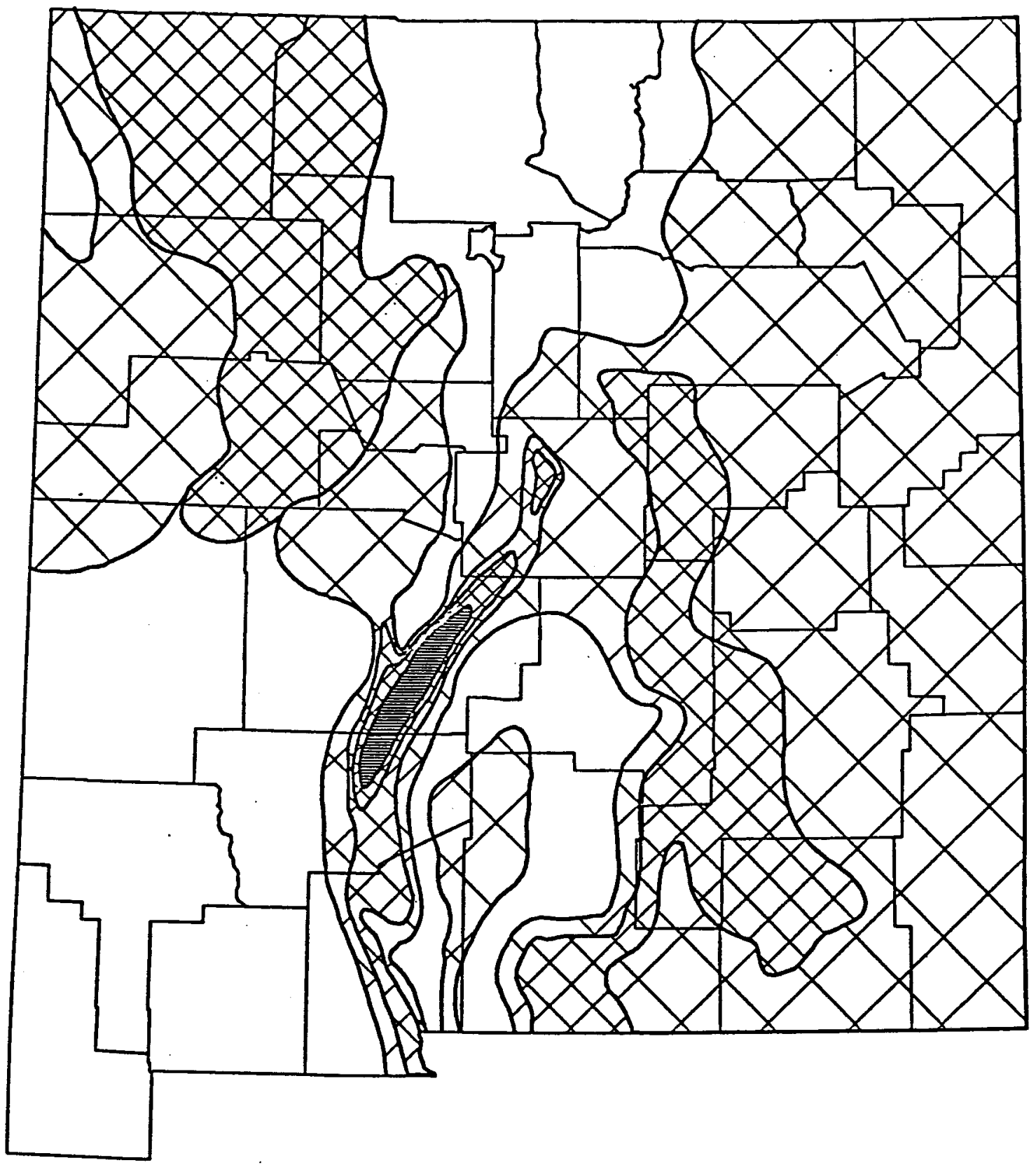

Figure 1-5. Estimated thickness of aquifers with very saline groundwater in New Mexico

Source: Bureau of Reclamation 1976 
There are a number of declared basins where new groundwater appropriations are possible, particularly for saline waters having more than $3000 \mathrm{mg} / \mathrm{L}$ TDS. An application must be filed with the state engineer who must find that the requested water resource is available, that existing uses are not impaired, and the proposed water application is not contrary to the conservation of water in the state or to public welfare. Legal protests from existing water users are likely to be lodged with the state engineer if an effort is made to use better quality water.

\subsection{Objectives}

The major objective of the research was to select potential locations for siting microalgae production facilities in New Mexico. The specific objectives of the research were to

1. Define areas within the state with saline aquifers with average depths to groundwater of less than $500 \mathrm{ft}$.

2. Determine those areas, as defined in objective 1 , that would provide water yields of less than 4 million gpd (12.3 acre-ft), 4 to 12 million gpd, and greater than 13 million gpd (40 acre-ft) without causing a serious decline in groundwater pumping levels and without a requirement for a large number of low-capacity wells.

3. Define the chemical composition (major ions and nutrients) of the groundwaters in areas that meet objectives 1 and 2 .

4. Define possible environmental or legal constraints of the use of these saline water resources, including those related to land acquisition and siting, and the impact on existing users and land subsidence.

\subsection{Literature Review}

\subsubsection{Microalgae Siting}

Little technical information is available in the literature concerning the siting of microalgae production facilities. Siting techniques have not been considered in feasibility studies of biomass fuel production facilities. For microalgae production facilities, there is a lack of specific information on potential sites or locations (New Mexico Solar Energy Institute 1978). The standard method of generalized siting has been to consider locations with desert lands and saline water resources. Site criteria have not been well defined, but a 1978 New Mexico report identified some requirements. These included ease of access and high rates of solar energy (New Mexico Solar Energy Institute 1978). Past studies implied that resources needed to develop a viable production facility must be cheap and abundant (Maxwell, Folger, and Hogg 1984).

The Solar Energy Research Institute (SERI) developed a stratification process for evaluating land and saline water resources of the Southwest for location of microalgae production facilities (Maxwell, Folger, and Hogg 1984). The evaluation process involved four steps:

1. An application and resource systems study

2. Overlay map production

3. Map digitization

4. Composite map preparation. 


\subsubsection{Agricultural Siting}

Some information is available concerning the location and siting of agricultural operations and energy production facilities that would use saline water (Hernandez 1986; Bureau of Reclamation 1984). Other associated studies are the Southwest Region Solar Pond Study (Boegl, Dahl, and Remmers 1983) and the Establishment of an Energy-Water Complex in the Tularosa Basin (Lansford et al. 1976). These two studies emphasized the feasibility of using these areas for producing energy or developing agricultural operations; siting was not a major issue.

\subsubsection{Saline Water Resources}

The data describing the saline water resources of New Mexico are abundant but inconsistent. Data sources include reports by the U.S. Geological Survey (USGS), the Bureau of Reclamation, the New Mexico State Engineers' Office, the New Mexico Bureau of Mines and Mineral Resources, the New Mexico Water Resources Research Institute, the New Mexico universities, and the U.S. Office of Saline Water Research and Development.

The following subsections contain brief literature reviews for the major saline groundwater basins in New Mexico.

\subsubsection{Rio Grande Basin}

The USGS prepared a report for the Rio Grande Drainage Basin titled Saline Ground Water Resources of the Rio Grande Drainage Basin--A Pilot Study (Kelly, Myers, and Hershey 1970). This study evaluated the saline water resources of the Rio Grande Drainage Basin of Colorado, New Mexico, and west Texas as potential sources for desalinization plants.

The identification of sites was based on water quality of slightly saline (1000 to $3000 \mathrm{mg} / \mathrm{L}$ TDS), moderately saline ( 3000 to $10,000 \mathrm{mg} / \mathrm{L}$ TDS), very saline (10,000 to $35,000 \mathrm{mg} / \mathrm{L}$ TDS), and brine (more than $35,000 \mathrm{mg} / \mathrm{L}$ TDS). The moderately saline groundwater areas favorable for development in New Mexico were the areas between the Middle Rio Grande and San Juan basins with saturated thicknesses as great as $5500 \mathrm{ft}$. In the Jornado del Muerto, the saturated thickness was as great as $5000 \mathrm{ft}$. Very saline groundwater areas favorable for development in New Mexico were the Jornado del Muerto-Estancia Basin complex with saturated thickness as great as $8000 \mathrm{ft}$. The slightly saline groundwater in the middle Rio Grande region of New Mexico is 500 to $1000 \mathrm{ft}$ below ground level (Kelly, Myers, and Hershey 1970). The moderately saline and very saline waters underlie the slightly saline groundwaters in the Rio Grande region.

\subsubsection{Tularosa Basin}

Extensive research has recently been conducted on the use of the saline groundwater resources of the Tularosa Basin of New Mexico (Hernandez 1986; Bureau of Reclamation 1984; Lansford et al. 1976). Hernandez's research was concerned with the identification of potential sites for irrigation with saline waters. The principal publication on groundwater characteristics is from the research conducted by McLean (1970) that identified characteristics, such as geographic location, potential well-yields, depth to water, and water quality (TDS). Within the alluvial valley, McLean (1970) provided well-yield information in four broad ranges: (1) areas with higher yields (greater than $700 \mathrm{gpm}$ ) that are along the alluvial boundary adjacent to the surrounding mountains; (2) the valley floor to the west of the area of interest where water depths are shallow $(50 \mathrm{ft})$, yields are low 
(50 gpm), and the water is saline; (3) a zone within the area of interest to the southwest that has estimated potential well-yields of less than $300 \mathrm{gpm}$ but greater than $50 \mathrm{gpm}$; and (4) the central region of the study area that has potential well-yields of 300 to 700 gpm.

McLean (1970) estimates the basin groundwater reserves as follows:

1. Freshwater resources on the east side of the valley are about 3 million acre-ft, and deposits on the west side contain about 7 million acre-ft of fresh water.

2. Slightly saline water (1000 to $3000 \mathrm{mg} / \mathrm{L}$ TDS) in the unconsolidated alluvial materials is estimated at 30 million acre- $\mathrm{ft}$.

3. Moderately and very saline water resources in storage are each on the order of 30 million acre-ft.

McLean (1970) and Hernandez (1986) also included comments on the suitability of the groundwaters of the Tularosa Basin for irrigated agriculture. By extension, suitability for irrigation implies that a microalgae production operation could be located in specifically defined geographic areas identified by Hernandez (1986). From these data sources, information was obtained to show that the majority of the SERI criteria for site selection can be met, including the criterion of topography.

\subsubsection{Estancia Basin}

Basic data for the groundwater resources of the Estancia Basin were taken from Smith (1957) and the New Mexico State Engineer (1975g). Additional well data were gathered with the help of the USGS (personal communications with Mr. Kim Ong of the Albuquerque, N. Mex., office). The report by Smith (1957) provided geologic information, water quality, depth, yields, and geographic locations within the basin.

\subsubsection{Salt Basin}

Basic groundwater data for the Salt Basin were obtained from a New Mexico State Engineer's Office report by Bjorklund (1957). In the valley fill between the areas of limestone to the east and west, Bjorklund reported well-yields ranging from 350 to $840 \mathrm{gpm}$, with several wells reporting more than $1000 \mathrm{gpm}$. Reported well-yields were derived from irrigation wells oriented in a north-south direction along the limestone outcropping in the central portion of the area. There were no published well-yield data for the alkali flats region at the southern end of the valley where water quality is the most saline and depths to groundwater are the shallowest. However, data from farmers in the area indicate that well-yields in excess of $1000 \mathrm{gpm}$ are not uncommon.

\subsubsection{Pecos Basin}

Basic data for groundwater resources of the Pecos Basin came from Geohydrology Associates (1978) and the city of Roswell, N. Mex. (personal communications with Charlie Sparnon). A detailed study of the area east of the Pecos River was conducted by Geohydrology Associates (1978) under contract with the U.S. Bureau of Land Management (BLM). Although prepared by a private consulting firm, the report of this study was placed in an open file with the New Mexico Bureau of Mines and Mineral Resources. The report covers all of Lea County and those portions of Eddy and Chaves counties lying east of the Pecos River. The Geohydrology Associates report contains water table maps, depth-to-water maps, a well-yield map, well records data, and 
water-quality data. Depth to water ranges from about 35 to $400 \mathrm{ft}$ in the area east of the Pecos River valley. In Chaves County, yields were estimated at only 5 to $10 \mathrm{gpm}$ (Geohydrology Associates 1978). In the Pecos Basin, Kelly, Myers, and Hershey (1970) identified areas with saturated thickness of approximately $1000 \mathrm{ft}$.

\subsubsection{Tucumcari Area}

Basic data for the groundwater resources of the Tucumcari area came from Berkstresser and Mourant (1966) and Trauger and Bushman (1964). Basic well data include depth, ionic composition, transmissivity, and potential well-yield. Well-yields are generally low; the production of municipal wells is between 150 and $300 \mathrm{gpm}$. Berkstresser and Mourant (1966) report the capacity of wells tapping the Entrada formation to range from 1.5 to $250 \mathrm{gpm}$. This is the result of the relatively poor transmissivity of the aquifer, which has been found to be less than $7000 \mathrm{gpd} / \mathrm{ft}$ of aquifer width in pumping tests. A number of lower values are reported by Trauger and Bushman (1964).

\subsubsection{San Juan Basin}

A detailed study of this region was conducted jointly by the New Mexico Bureau of Mines and Mineral Resources, the USGS, and the New Mexico State Engineer (Stone et al. 1983) during the period of peak interest in energy-resource development. The report covers all of San Juan County and parts of Bernalillo, Cibola, McKinley, Rio Arriba, and Sandoval counties. It includes data on structure, depth, and thickness of all aquifers and depth to water as well as potentiometric surface maps for most confined aquifers, various aquifer properties, and water quality. In the San Juan Basin, Kelly, Myers, and Hershey (1970) identified areas with saturated thickness as great as $7000 \mathrm{ft}$. Potential well-yields are commonly 25 to $100 \mathrm{gpm}$.

\subsubsection{Ogallala Aquifer}

Two studies were used to review the Ogallala Aquifer High Plains portion of New Mexico as an area with potential for siting a microalgae production facility. Lansford et al. (1982) and Krothe and Weeks (1982) determined depth to groundwater and salinity in terms of TDS, respectively. At depths that range from 10 to $325 \mathrm{ft}$, salinity in terms of TDS ranged from 500 to $1000 \mathrm{mg} / \mathrm{L}$ as determined by Krothe and Weeks (1982). Generally, below $500 \mathrm{ft}$, groundwater quality deteriorates to levels that would be acceptable according to SERI criteria. However, at greater depths, the well-yields in the aquifer tend to be low as salinity increases. 


\subsection{METHODOLOGY}

The emphasis of the research was twofold. First, a data base was created based on SERI criteria for location of a microalgae production facility. Specific criteria include location, depth to the aquifer, saturated thickness of the aquifer, aquifer characteristics, growing season, salinity, ionic composition, well-yields, topography, and ownership. Second, the data base was digitized to enable required map construction.

Statewide consideration of all groundwater basins was not feasible because of the legal and institutional framework of water rights within New Mexico. This research reflects the analysis of a selected group of groundwater basins within New Mexico that have known, unappropriated saline water resources. The following subsections outline the eight research tasks.

\subsection{Task 1}

Basins were chosen based on published reports and verbal communications with the New Mexico State Engineer's Office and other federal and state water agencies. Guidelines for basin selection were based on the availability of potential unappropriated water and the feasibility of using this water in a beneficial manner.

Within areas containing potentially available and appropriable groundwater, based on information from the New Mexico State Engineer's Office, a data base was constructed following SERI criteria. Data to be used in tasks 2 through 8 were collected on selected basins. Data included groundwater quality and quantity and land surface characteristics. The sources for the majority of these data were published maps and charts and individual well data.

\subsection{Task 2}

The second task was to define depth to groundwater. Where possible, the depth to saline water was mapped in isorythmic form based on data from individual wells. The economic recoverability criteria of $500 \mathrm{ft}$ of depth were adjusted by individual basin, and calculations of total dynamic head (TDH) (the distance from the water level in the well during pumping to the point of discharge above ground level plus all other energy losses) were made where possible.

The pumping lift is an economic consideration. Net returns per acre of pond (not taking capital recovery into account) will depend on pond size, the source of the water supply, the quality of the supply, the makeup water required, and the pumping depth. Pumping lifts in excess of $500 \mathrm{ft}$ will seriously affect the profitability of an algae culture operation. The TDH should not exceed $500 \mathrm{ft}$ unless other factors change the economics of the operation.

\subsection{Task 3}

Well-yields were mapped in isorythmic form, where possible, and were based on data for specific wells. In addition, a calculation was made to determine the well-yields needed for a 1000-ha facility in a region with a given rate of evaporation. The characteristics of the saline water source available at a particular site for use in algae production are probably the most important factor in selecting or rejecting an area. 
First, there must be a sufficient supply. Wells should have a yield at least sufficient to meet the net evaporation in the area during the peak summer months. A commonly used rule of thumb is that the water supply capacity required for irrigated agriculture must be about 5 to $10 \mathrm{gpm}$ for every acre irrigated.

After completing the first three tasks, a set of maps was developed that grossly identified those areas with the greatest possibilities for microalgae production. The maps, presented in the following sections, are based on published information or are adapted from published maps. All maps are geographically correct. Base maps included BLM land status maps, USGS topographic maps, hydrologic unit maps of the state, and various published maps from the state engineer and the USGS. Each generated map is a single color and portrays an individual variable. This approach was used for simplicity and clarity.

After individual criteria were mapped and the associated tasks completed, individual estimations were made of the quantity of water, water quality including $\mathrm{pH}$, and potential recharge rates. Areas that met the SERI criteria were mapped for each basin. Each map contains information for a single variable.

\subsection{Task 4}

Basins were further limited by climate criteria. Data on growing season, precipitation, solar energy, temperature, and evaporation were collected from the state climatologist, and additional maps were constructed.

Net annual evaporation rates from ponds are site specific and a function of elevation, wind velocity and duration, precipitation, temperature, and relative humidity. Evaporation rates during peak months are also a function of site location. Peak months for New Mexico are normally June, July, and August. Evaporation during these months can constitute almost half of the total annual water loss from a small lake in southern New Mexico. If the peak month represents $15 \%$ of the total evaporation, and the rate of evaporation for a saline pond in southern New Mexico is assumed to be $6 \mathrm{ft} / \mathrm{yr}$, then the combined daily rate of production from wells that supply a section (640 acres) of algae pond area must be about $6.3 \mathrm{mgd}$. If wells are only expected to pump $70 \%$ of the time during summer peak periods, then the combined rate of production of the wells that service a section of land must be about $6250 \mathrm{gpm}$, or approximately $10 \mathrm{gpm} / \mathrm{acre}$. If 15 wells is the maximum that can serve a section of land (assuming a minimum spacing of $1000 \mathrm{ft}$ between wells to avoid interference), then the minimum acceptable capacity of a well is $400 \mathrm{gpm}$ for evaporation rates in southern New Mexico. Lower-capacity wells could possibly be acceptable in northern New Mexico. If serious leakage from a pond bottom occurs, additional well capacity will be required.

\subsection{Task 5}

Potential sites for microalgae production facilities were further constrained by land ownership and land use. Ownership was described as private, federal, or state but mapped as either public or private to reduce complexity.

In New Mexico, traditional patterns of land use and ownership were detailed by individual basin in tabular form. Maps for each basin describe land ownership as either public or private. The only type of land ownership that would strictly prohibit microalgae production facilities would be federal military lands. There are land uses that can prohibit microalgae production facilities. These include national parks; Indian lands; and, possibly, 
irrigated cropland. Land ownership was derived from BLM land status maps at scales of 1:1,000,000.

\subsection{Task 6}

The next constraint for site selection was the maximum slope criteria of $2 \%$ as set forth by SERI.

Areas that met the land slope criteria of no greater than $2 \%$ slope were determined for each basin. Within a given basin, the criteria were met using a template that allowed measurement of areas in topographic maps where altitude change given linear change does not exceed $2 \%$.

\subsection{Task 7}

Water-quality data (salinity and ionic composition) were gathered for individual wells and isorythmic maps were constructed. The report titled New Mexico Water Resources: Assessment for Planning Purposes (Bureau of Reclamation 1976) characterizes saline groundwater resources as slightly saline, moderately saline, very saline, and brine based on milligrams per liter of TDS. For purposes of this research, groundwater was considered in terms of TDS. In addition, individual well data for basins of interest were collected, and specific ionic compositions of water were recorded. Ions of interest were silicon, iron, calcium, magnesium, sulfate, bicarbonate, chlorine, sodium, and potassium.

\subsection{Task 8}

The final task was to briefly describe the environmental and legal issues for areas that were selected as potential sites.

The concept of water conservation in New Mexico is best served by the beneficial use doctrine. This doctrine pertains to all state water resources, including those waters with high TDS contents. Algae culture using saline waters could result in the preservation or saving of fresh water.

Based on past decisions by the state engineer, it is clear that actions that lead to significant changes in water quality must be considered as potential sources of impairment of existing water rights. Seepage from a saline algae pond that leaks downward into a freshwater aquifer could lead to significant degradation and, thus, must be considered an impairment of an existing water right (Kelly, Myers, and Hershey 1970). Sites where the quality of a shallow fresh-water aquifer will be subject to contamination by the use of saline water will not be acceptable.

The major environmental concerns are groundwater degradation from pond seepage, encroachment of saline groundwater on fresh-water aquifers, toxic ionic buildup in exposed pond waters, and brine disposal of pond waters.

The buildup of specific ions in saline pond waters is also of concern. A number of naturally occurring chemical constituents in water have no adverse effects on wildlife in the concentrations in which they are normally found. However, unique situations do occur where these constituents are found in greater quantities, and their concentration in ponds may result in serious environmental problems. An example is the relatively high levels of selenium that have developed in wet-lands vegetation growing in irrigation drain waters in the central valley of California (Burau 1985). Another consideration of specific ion buildup is possible disposal problems. 


\subsection{RESULTS}

The first two tasks of the methodology were used to reduce to a workable number the potential areas suitable for large-scale (1000 ha) microalgae production facilities. The reduced number of potential areas was then screened using tasks 3 and 4 . Detailed maps were prepared for tasks 5 and 6. Finally, detailed analyses were prepared for the areas with the highest potentials for the location of large-scale microalgae production facilities. Tasks 7 and 8 were then utilized to prepare the descriptions of these selected sites.

\subsection{Climate and Surface Characteristics}

Five maps were developed to provide a description of statewide climate characteristics-growing season, mean daily temperature, annual precipitation, annual mean daily solar radiation, and annual lake evaporation. These maps do not reflect sudden changes that can occur in microclimates but generally reflect what occurs within basins. These climatic maps are presented in Appendix A.

A set of two maps for each basin was constructed to detail the land surface characteristics--land ownership (ownership was broken into federal, state, and private) and land slope (areas with greater than $2 \%$ slope were eliminated from consideration).

\subsection{Groundwater Quality}

Detailed composition of groundwater by basin for major ions, $\mathrm{pH}$, and specific conductance is presented in tabular form later in the document.

\subsection{Unappropriated Saline Water Resources}

New Mexico follows the doctrine of prior appropriation in establishing the right to use water and does not make any quality distinction between fresh and saline water in its methods of assigning priorities and recognizing rights for the use of surface water or groundwaters. The available water supply for algae production in New Mexico will probably be limited to the unappropriated moderately or very saline waters because of the current allocation of better-quality water to existing uses. Both fresh and slightly saline waters are now used for domestic, industrial, and agricultural purposes. Moderately saline waters ( 3000 to $10,000 \mathrm{mg} / \mathrm{L}$ TDS) and more saline supplies are used sparingly at this time.

The New Mexico state engineer identified areas in New Mexico with unappropriated groundwater in a letter to Charles DuMars (1984). This communication was amended in a letter to Charles DuMars from S. E. Reynolds, New Mexico state engineer, dated December 26, 1985 (DuMars et al. 1986). These estimates are presented in Table 3-1.

Personnel from the New Mexico Bureau of Mines and Mineral Resources, USGS, and other state and federal water-related agencies discussed those basins identified by the New Mexico state engineer as having unappropriated groundwater. They were asked about more precise location, availability of data on depth to the saline groundwaters, wellyields, and the quantity of water available.

\subsection{Basin Selection}

After completing the first two tasks, the state was effectively limited to six groundwater basins as areas having the greatest potential for siting microalgae production 
Table 3-1. Water Available for New Appropriations in Declared Underground Water Basins

\begin{tabular}{lc}
\hline \multicolumn{1}{c}{ Basin } & $\begin{array}{c}\text { Unappropriated } \\
\text { Groundwater } \\
\text { (million acre-ft) }\end{array}$ \\
\hline Closed Aquifers & \\
\hline Animas & 0.00 \\
Estancia & 2.04 \\
Hueco & 6.20 \\
Jal & 0.04 \\
Lea County & 0.77 \\
Lordsburg & 0.60 \\
Mimbres & 3.70 \\
Nutt-Hockett & 0.13 \\
Tucumcari & 0.40 \\
Tularosa & 10.70 \\
& \\
Tributary Aquifers & \\
\hline Upper Rio Grande & \\
Middle Rio Grande & 9.30 \\
Lower Rio Grande & 2.70 \\
Pecos River & 5.00 \\
San Juan & 8.00 \\
\hline
\end{tabular}

Source: DuMars et al. 1986

facilities. These basins were the Tularosa Basin, the Estancia Basin, the Crow Flats Basin, the Tucumcari area, the Pecos Basin, and the San Juan Basin (Figure 3-1).

The Animas, Lordsburg, Mimbres, and Nutt-Hockett basins were eliminated based on water-quality considerations. Nearly all the unappropriated groundwaters in these basins are classified as fresh or slightly saline (Figures 1-3 and 1-4). The Jal, Lea County, Upper Rio Grande, Middle Rio Grande, and Lower Rio Grande were eliminated based on depth to moderately to very saline groundwater resources. In these basins, nearly all the saline water is overlaid by fresh water.

The Hueco Basin was eliminated because of the moderately to very saline groundwaters located near the edge of the basin that are overlaid by fresh water. The center of the basin also includes part of the Fort Bliss Military Reservation.

The Tularosa Basin lies in south-central New Mexico and is part of the Central Closed Basin. There are large quantities of unappropriated saline groundwater in the Tularosa Basin. Alamogordo is the principal city in the basin.

The Estancia Basin is in central New Mexico just north of the Tularosa Basin. It is also part of the Central Closed Basin. The unappropriated groundwaters tend to be in the saline waters on the east side of the basin. 


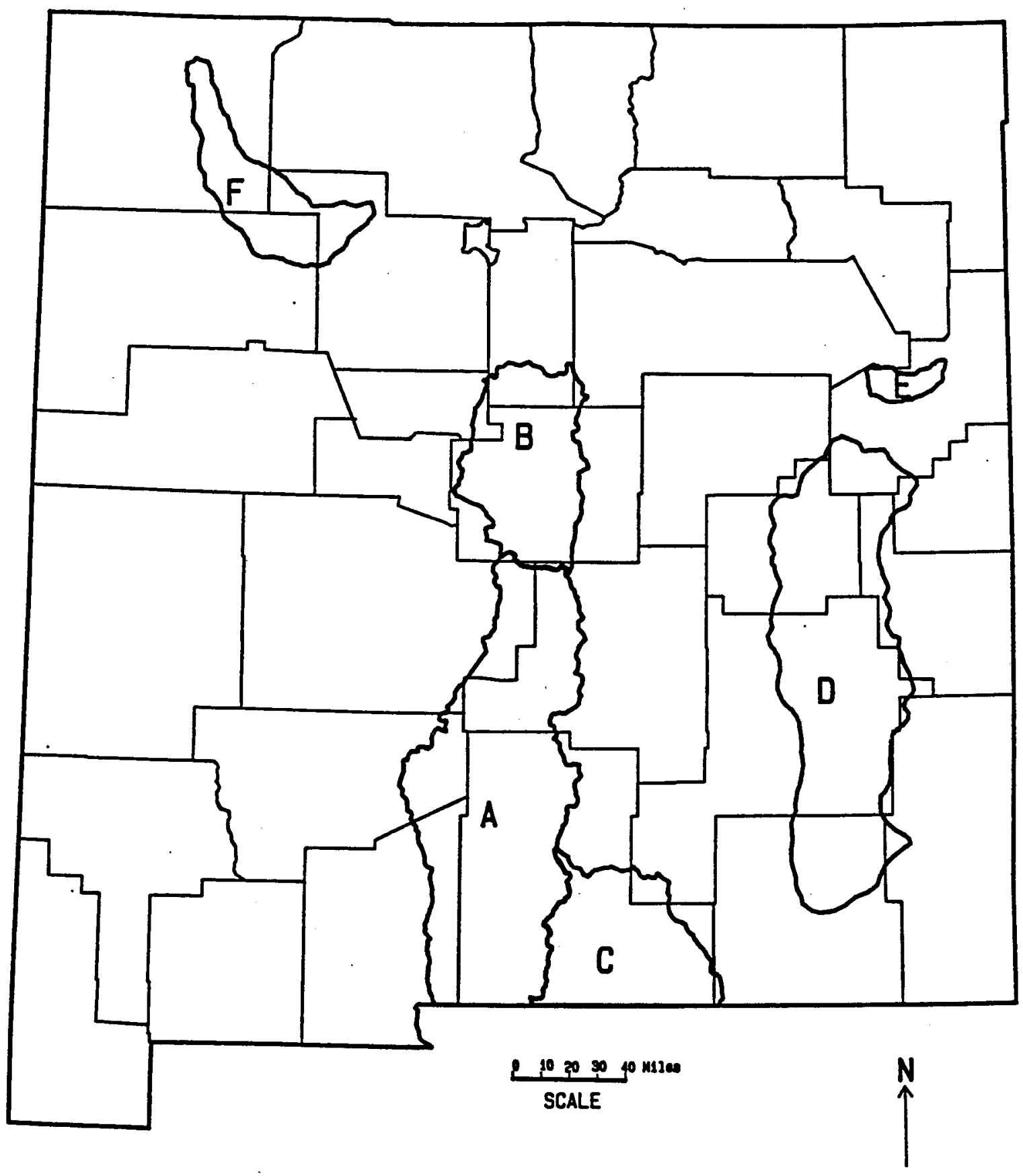

$$
\begin{aligned}
& \text { A - Tularosa Basín } \\
& 8 \text { - Estancia Basin } \\
& \text { C - Crow Flats Basin }
\end{aligned}
$$$$
\text { D - Pecos Basín }
$$$$
\text { E - Tucuncar1 Basin }
$$$$
\text { F - San Juan Basín }
$$

Figure 3-1. Microalgae study areas in New Mexico 
The Crow Flats Basin within the Salt Basin is southeast of the Tularosa Basin and is also part of the Central Closed Basin. However, the Salt Basin is not a declared basin, but there are large quantities of unappropriated groundwaters in the basin.

The Tucumcari Basin is part of the Canadian River Basin in northeastern New Mexico. The unappropriated groundwater is primarily irrigation return flows.

The unappropriated groundwaters in the Pecos Basin generally lie between the Pecos River and the Ogallala Aquifer to the east. This region also has large areas of saline groundwaters.

The San Juan Basin in northwestern New Mexico is part of the Colorado Plateau. The San Juan Basin is of potential interest for microalgae production because moderately saline water lies at a depth of less than $500 \mathrm{ft}$ in most places and less than $200 \mathrm{ft}$ in some areas.

The following subsections present a detailed description of the analysis of the six groundwater basins selected for analysis.

\subsection{The Tularosa Basin}

\subsubsection{Introduction}

The Tularosa Basin in south-central New Mexico was selected as having a high potential for the location of a large-scale (1000 ha) microalgae production facility. The Tularosa Basin is part of the Central Closed Basin in New Mexico. It is bordered by the Rio Grande Basin to the west, the Pecos River Basin to the east, the Estancia Basin to the north, and the state of Texas to the south (Figure 3-2). The area of the Tularosa drainage basin is $6540 \mathrm{mi}^{2}$ (Bureau of Reclamation 1976). Elevations within the basin range from more than $12,000 \mathrm{ft}$ in the eastern mountains to less than $4000 \mathrm{ft}$ in the alkali flats in portions of the central valley.

\subsubsection{Setting and Climatic Characteristics}

The major cities of the Tularosa Basin are Alamogordo and Tularosa. These cities compose the bulk of the approximately 50,000 persons that live within the basin (Diemer and Morrison 1984). Other population centers in the basin are the White Sands Missile Range and Holloman Air Force Base.

The climate in the Tularosa Basin is typical of the arid to semiarid regions of the southwestern United States. Table 3-2 presents a summary of climatic information for the Alamogordo, Tularosa, Cloudcroft, and Orogrande stations. Alamogordo, Tularosa, and Orogrande are typical of the central portion of the basin, and Cloudcroft is typical of the bordering mountains. The mean annual precipitation in the basin ranges from 8.8 in. in the central portion of the basin at Orogrande to $25.4 \mathrm{in}$. at Cloudcroft in the bordering mountains. Precipitation on the slopes of the surrounding mountains produces intermittent stream runoff that drains toward the center of the basin or moves as groundwater flow through the alluvial fans as interflow. The intense summer thunderstorms produce high runoff of short duration, most of which flows into the playas or alkali flats and evaporates. Temperatures in the basin range from an average of about $61^{\circ} \mathrm{F}$ in the central portion of the basin to about $45^{\circ} \mathrm{F}$ in the bordering mountains (Table 3-2). 


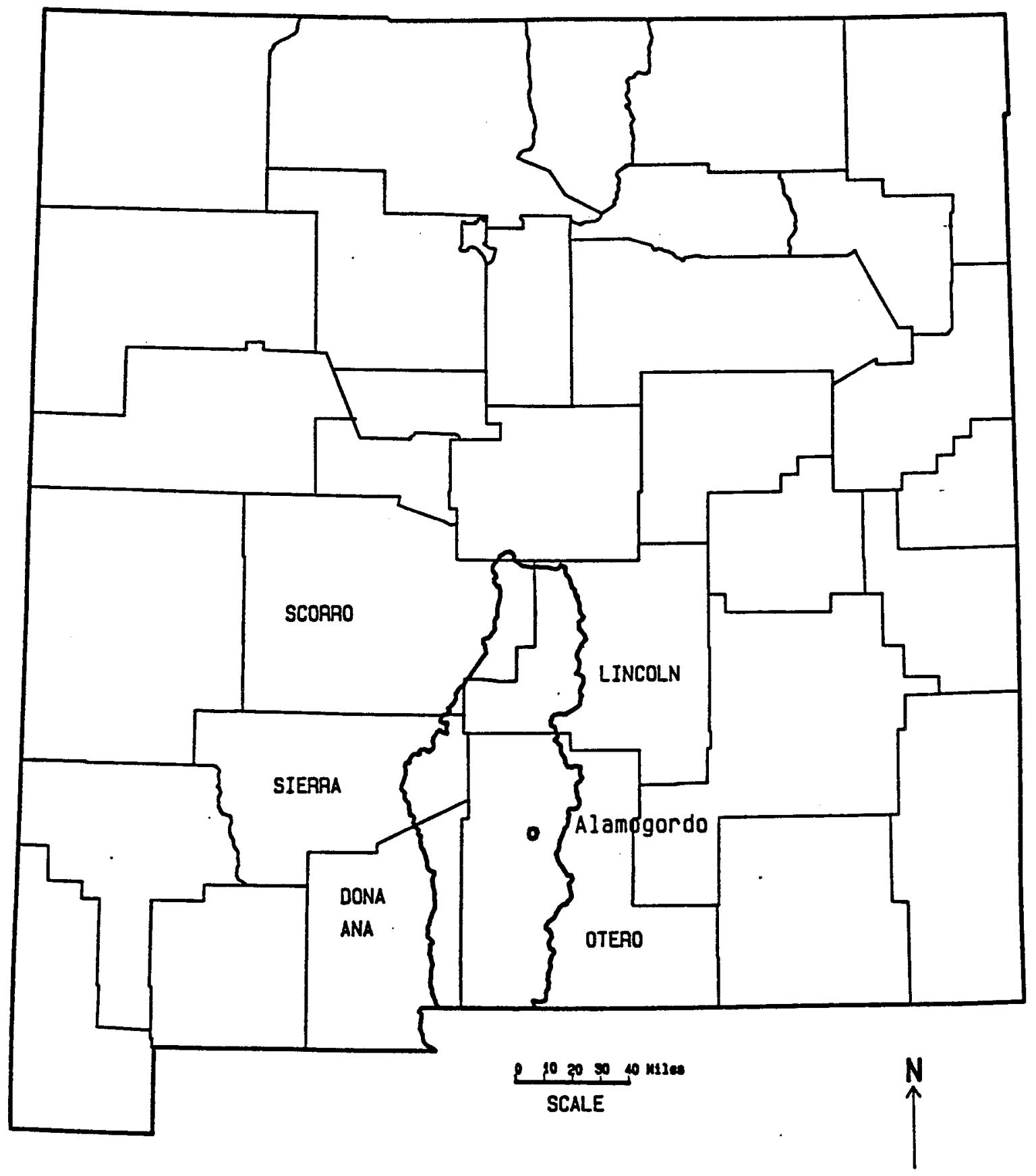

Figure 3-2. Location of the Tularosa Basin, New Mexico 
Table 3-2. Selected Climatic Data for Stations within the Tularosa Basin, New Mexico

\begin{tabular}{|c|c|c|c|c|c|}
\hline & Units & Alamogordo & Tularosa & Orogrande & Cloudcroft \\
\hline $\begin{array}{l}\text { Elevation } \\
\text { (above msl) }\end{array}$ & feet & 4350 & 4460 & 4200 & 8827 \\
\hline $\begin{array}{l}\text { Average days } \\
\text { above } 32^{\circ} \mathrm{F}\end{array}$ & days & 209 & 211 & -- & -- \\
\hline $\begin{array}{l}\text { Average frost- } \\
\text { free period }\end{array}$ & date & $\begin{array}{r}\text { April 7- } \\
\text { November } 2\end{array}$ & $\begin{array}{r}\text { April 4- } \\
\text { November } 1\end{array}$ & - & -- \\
\hline $\begin{array}{l}\text { Mean annual } \\
\text { precipitation }\end{array}$ & inches & 9.8 & 10.1 & 8.8 & 25.4 \\
\hline $\begin{array}{l}\text { Maximum mean } \\
\text { monthly air } \\
\text { temperature }\end{array}$ & $\mathrm{mo}-^{\circ} \mathrm{F}$ & $\begin{array}{l}\text { July- } \\
79.7\end{array}$ & $\begin{array}{l}\text { July- } \\
80.4\end{array}$ & $\begin{array}{l}\text { July- } \\
81.5\end{array}$ & $\begin{array}{r}\text { July- } \\
59.9\end{array}$ \\
\hline $\begin{array}{l}\text { Minimum mean } \\
\text { monthly air } \\
\text { temperature }\end{array}$ & $\mathrm{mo}-{ }^{\circ} \mathrm{F}$ & $\begin{array}{r}\text { January- } \\
42.0\end{array}$ & $\begin{array}{r}\text { January- } \\
43.4\end{array}$ & $\begin{array}{r}\text { January- } \\
42.0\end{array}$ & $\begin{array}{r}\text { January- } \\
30.0\end{array}$ \\
\hline $\begin{array}{l}\text { Average annual } \\
\text { air temperature }\end{array}$ & ${ }^{\circ} \mathrm{F}$ & 61.3 & 61.7 & 61.9 & 45.0 \\
\hline
\end{tabular}

Source: Lansford et al. 1976

The bulk of the private land in the basin and the bulk of the lands under irrigated agriculture lie within Lincoln and Otero counties. The major crops grown in the Tularosa Basin are alfalfa, planted pasture, and orchard crops (Lansford et al. 1985). The majority of irrigated agriculture exists along a strip of land from Alamogordo to north of Tularosa. This strip of agriculture along Highway 54 runs north to south, close to the mountains that border the eastern edge of the valley portion of the basin. Groundwater quality and yields are suitable for irrigated agriculture in these areas.

\subsubsection{Study Area}

For the purpose of siting a microalgae production facility within the Tularosa Basin, a limited study area was identified (Figure 3-3). It lies in Otero County on the east side of the valley floor along the alluvial fans generated by the drainage systems from the mountains just to the east. The city of Alamogordo is within the area of interest. The borders of the area are Township 13 South (T.13 S.) on the north, T.20 S. on the south, Range 8 East (R8E) on the west, and R.11 E. on the east, inclusive.

\subsubsection{Land Ownership and Slope}

The maps of land ownership and slope were developed (Figures 3-4 and 3-5, respectively). A further breakdown of ownership would require a field survey because of the 


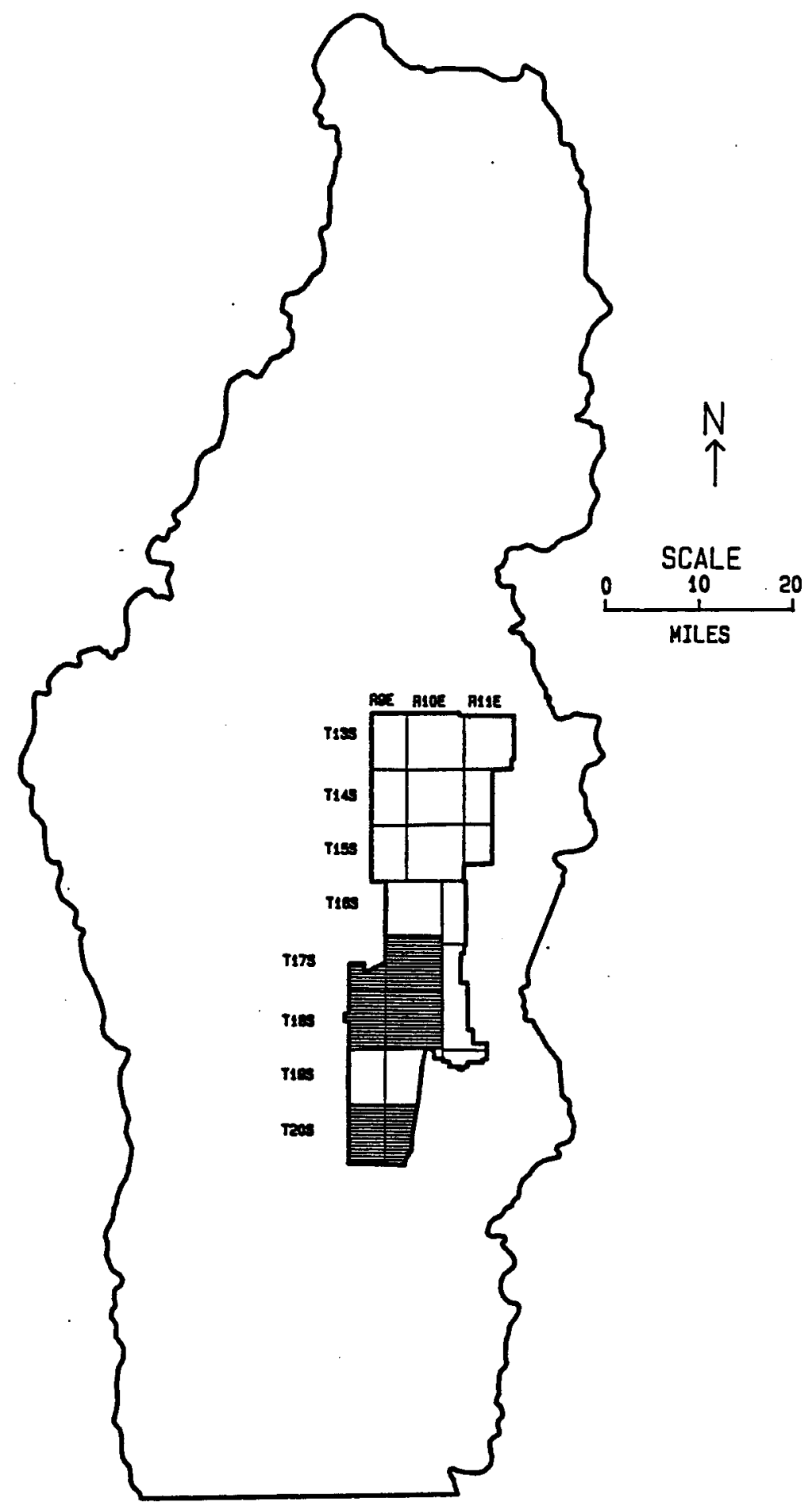

Figure 3-3. Study area and potential production areas in the Tularosa Basin, New Mexico 


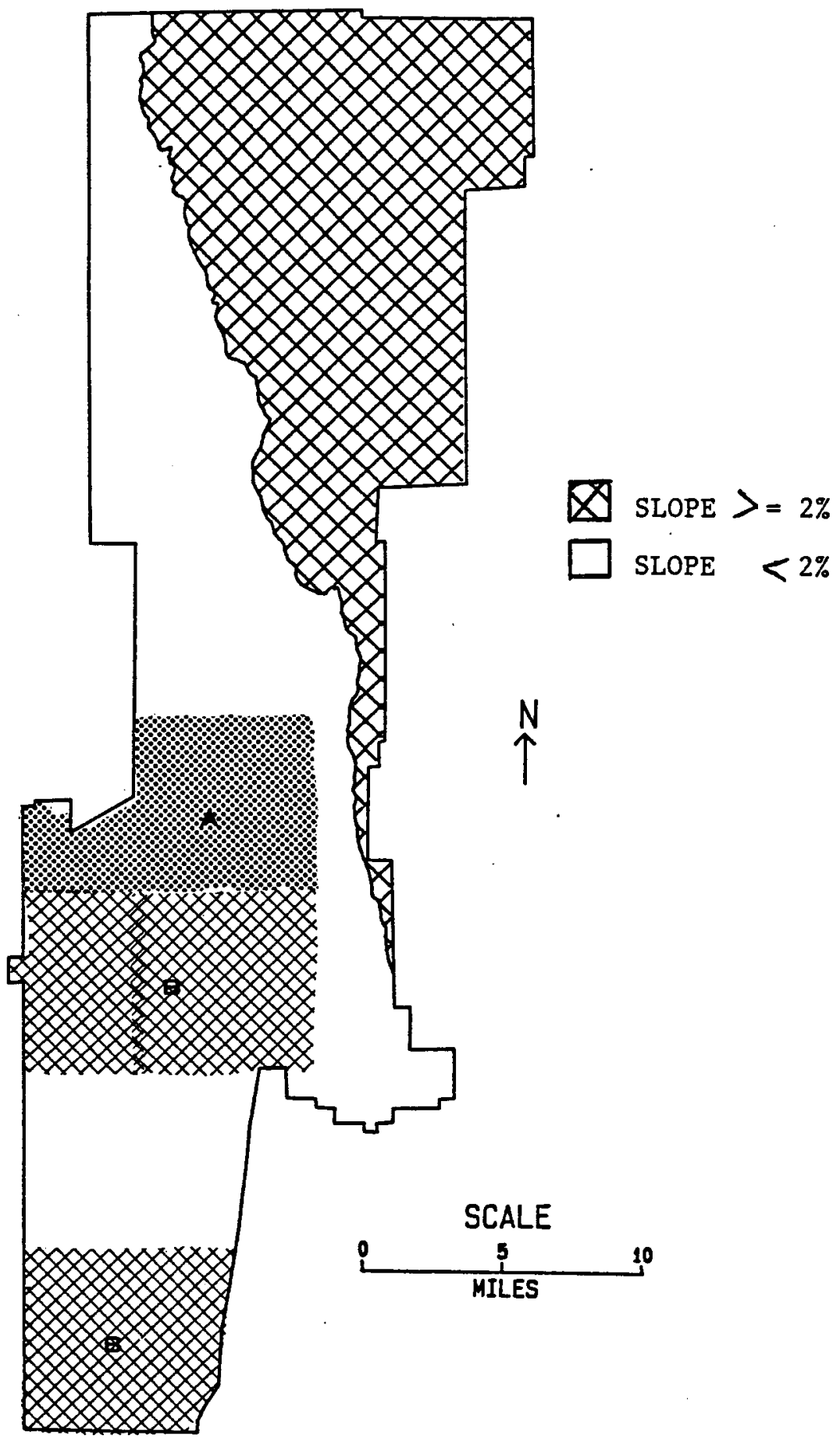

Figure 3-4. Tularosa Basin, places with land slopes that exceed $2 \%$ within the study area and potential production areas 


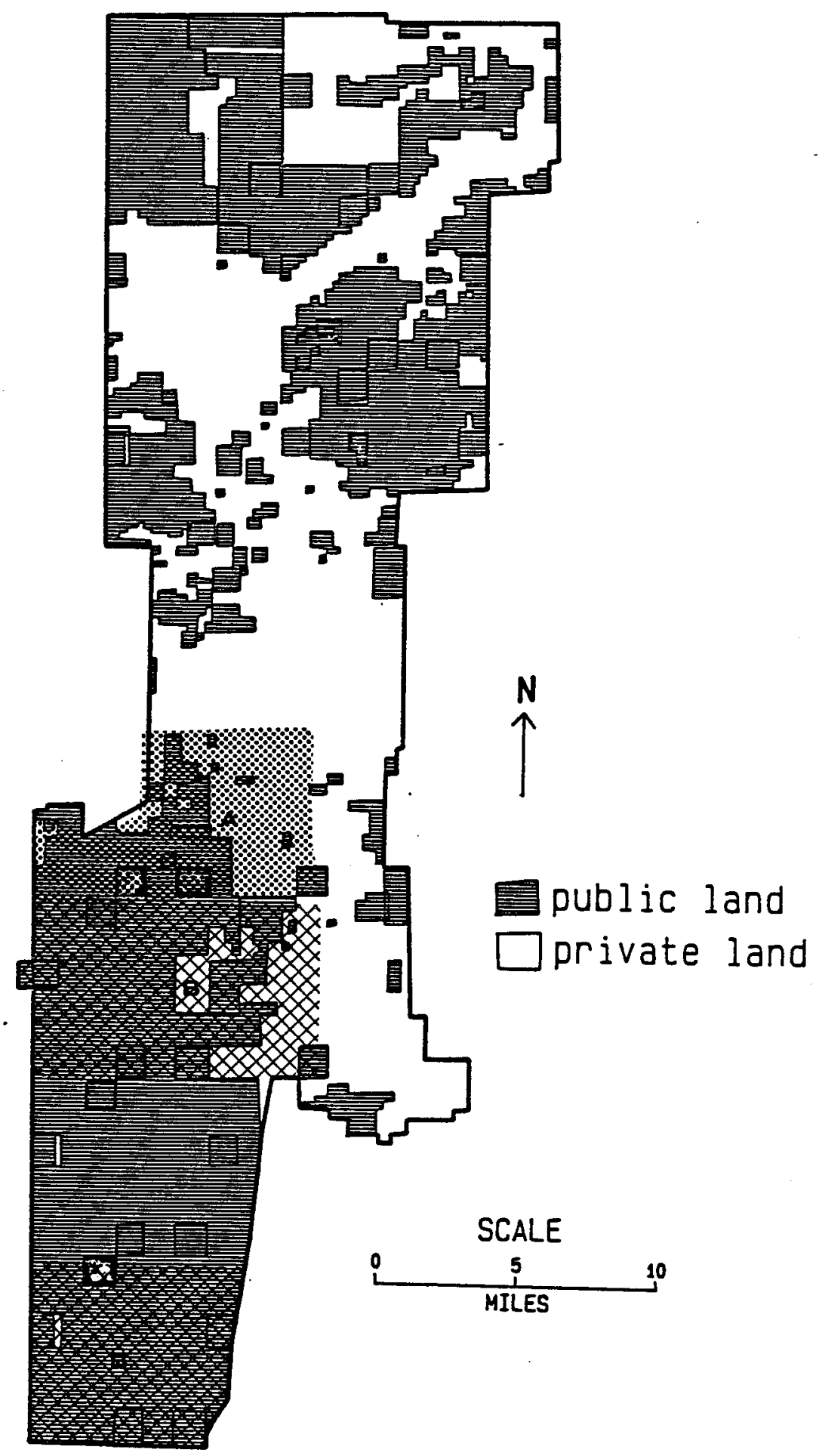

Figure 3-5. Tularosa Basin, land ownership within the study area and potential production areas 
mixture of land ownership. Land use was determined to be closely tied to land ownership, i.e., military activities or livestock grazing on federal lands.

North of this study area, potential sites for microalgae production facilities are limited by slopes of greater than $2 \%$ and the outcrop of consolidated rock that forms the upper boundary of the alluvial valley. To the east and south, acceptable locations are limited by the Lincoln National Forest, the Mescalero Apache Indian Reservation, and the Fort Bliss Military Reservation (McGregor Range). Land slope is a further constraint on the eastern boundary. To the west of the study area, the availability of sites is limited by the White Sands Missile Range, which occupies a majority of the western half of the Tularosa Basin. White Sands National Park is also in the valley floor to the west of the identified tract. Land ownership was digitized by public and private ownership within the study area. This represents the area with the greatest potential for location of a microalgae production facility within the Tularosa Basin.

\subsubsection{Water Resources}

For the purposes of this report, a static water level of $250 \mathrm{ft}$ was determined to be the maximum, economically feasible depth from which groundwater could be used for microalgae production in the Tularosa Basin. This further restriction on aquifer depth was based on aquifer characteristics, anticipated drawdown in wells, and site topography.

Basic data for the groundwater resources of the Tularosa Basin were taken from McLean (1970) and Hernandez (1986). Additional well data were obtained from USGS personnel.

Recharge of the groundwater resources of the Tularosa Basin comes principally from precipitation in the mountains that forms the western, northern, and eastern boundaries of the basin. As noted earlier in this section, the precipitation at higher elevations is more than $20 \mathrm{in} . / \mathrm{yr}$. Recharge occurs in two ways: (1) infiltration and deep percolation into the aquifers exposed at high elevations and eventual discharge as springs or seeps in the central valley floor or (2) movement through the alluvial materials in the channels that carry runoff from the better-watered areas of the basin into the central valley. From McLean (1970), it is clear that there is an abundant reserve of saline waters in storage that can be readily used for microalgae culture. For example, the moderately saline water resources can support 100 sections of algae ponds in the central valley area for a period of 100 years ( 5 acre-ft of net evaporative losses per year per acre over a 640-acre area per section times 100 sections for a total annual water consumption of 320,000 acre-ft).

\subsubsection{Groundwater Quality}

The water-quality classes are as follows: fresh water with less than $1000 \mathrm{mg} / \mathrm{L}$ TDS; slightly saline water $(1000$ to $3000 \mathrm{mg} / \mathrm{L}$ TDS); moderately saline (3000 to $10,000 \mathrm{mg} / \mathrm{L}$ TDS); and very saline ( 10,000 to $35,000 \mathrm{mg} / \mathrm{L}$ TDS). In areas where the presence of more than one quality of water is indicated, the better-quality water overlies the more saline water.

Density stratification, with the more saline water at the lower level, is the rule in this basin, but at places where water of two different dissolved solid concentrations meet, one of the two may be a thin zone. A well located at such a point would take water from both water-quality zones. In this respect, McLean (1970) reports the following: 
The intertonguing of saline-water units and the heterogeneity of alluvial deposits make it difficult to find areas where large quantities of water of a specific quality might be obtained. As pumping progresses over months or years, the total dissolved solids in a well may change due to the influx of either more saline or less saline water. The individual ions may likewise change.

\subsubsection{Potential Production Areas}

Two possible sites that met SERI's criteria for location of a large-scale ( 1000 ha) microalgae production facility were identified within the Tularosa Basin (Figure 3-6). An area of approximately $115 \mathrm{mi}^{2}$ composed of two distinct sites was selected based on availability of moderately and very saline groundwater. The basic SERI site-selection criteria and groundwater characteristics are presented in Table 3-3 for each of the sites.

\subsubsection{Site A}

Site A encompasses approximately $40 \mathrm{mi}^{2}$ (approximately 25,000 acres) and lies in T.17 S., R.8, and 9 E. (Figure 3-3). This area is southwest of Alamogordo and borders on White Sands Missile Range and Holloman Air Force Base. The slope criteria (not greater than 2\%) is met within this area (Table 3-3 and Figure 3-4). Land ownership in this area is approximately $40 \%$ private, $35 \%$ federal, and $25 \%$ state owned (Figure $3-5$ ). The growing season is more than $200 \mathrm{~d}$.

Figures 3-7 through 3-9 present the alluvial boundary and the locations and saturated thicknesses of different qualities of water within the study area. Groundwater quality in the site is between 10,000 and $35,000 \mathrm{mg} / \mathrm{L}$ TDS and has a range of saturated thickness as great as $2000 \mathrm{ft}$. Potential well-yields are about $300 \mathrm{gpm}$ for the entire area (Figure 3-10), and the depth to groundwater is less than $50 \mathrm{ft}$ (Figure 3-11). In terms of an acceptable site, well-yields are marginal because a minimum of ten wells will be required to meet the SERI criteria of well production of 4 million gpd. More than 30 wells would be required to meet the SERI criteria of production of 13 million gpd.

The reserves of saline water in storage were estimated for the site A potential production area. Reserve estimates were based on a saturated thickness of 250 to $500 \mathrm{ft}$ and a storage coefficient (effective porosity) of $6 \%$ to $10 \%$. The recoverable volume of water in storage would be about 385,000 to $1,248,000$ acre- $\mathrm{ft}$. Recharge of groundwater within the basin occurs primarily from precipitation and runoff within the closed basin.

The groundwater quality in this site is classified as very saline with a range from 10,000 to $35,000 \mathrm{mg} / \mathrm{L}$ TDS (Table 3-3). There is almost no occurrence of groundwater of less than $3000 \mathrm{mg} / \mathrm{L}$ TDS. The $\mathrm{pH}$ of the groundwater ranges from 7.0 to 7.6. The ionic concentrations for the groundwater of the area are also presented in Table 3-3. Sulfate and chloride ions have the highest concentrations.

\subsubsection{Site B}

This area encompasses approximately $75 \mathrm{mi}^{2}$ and meets all of the SERI criteria (Figure 3-3). It is located in T.18 S., R.8 and $9 \mathrm{E}$. and T.20 S., R.8 and $9 \mathrm{E}$. The site characteristics are similar to site A, with the exception of land ownership (Table 3-3). Land ownership patterns approximate the following: $15 \%$ federal, $10 \%$ state, and $75 \%$ private. 


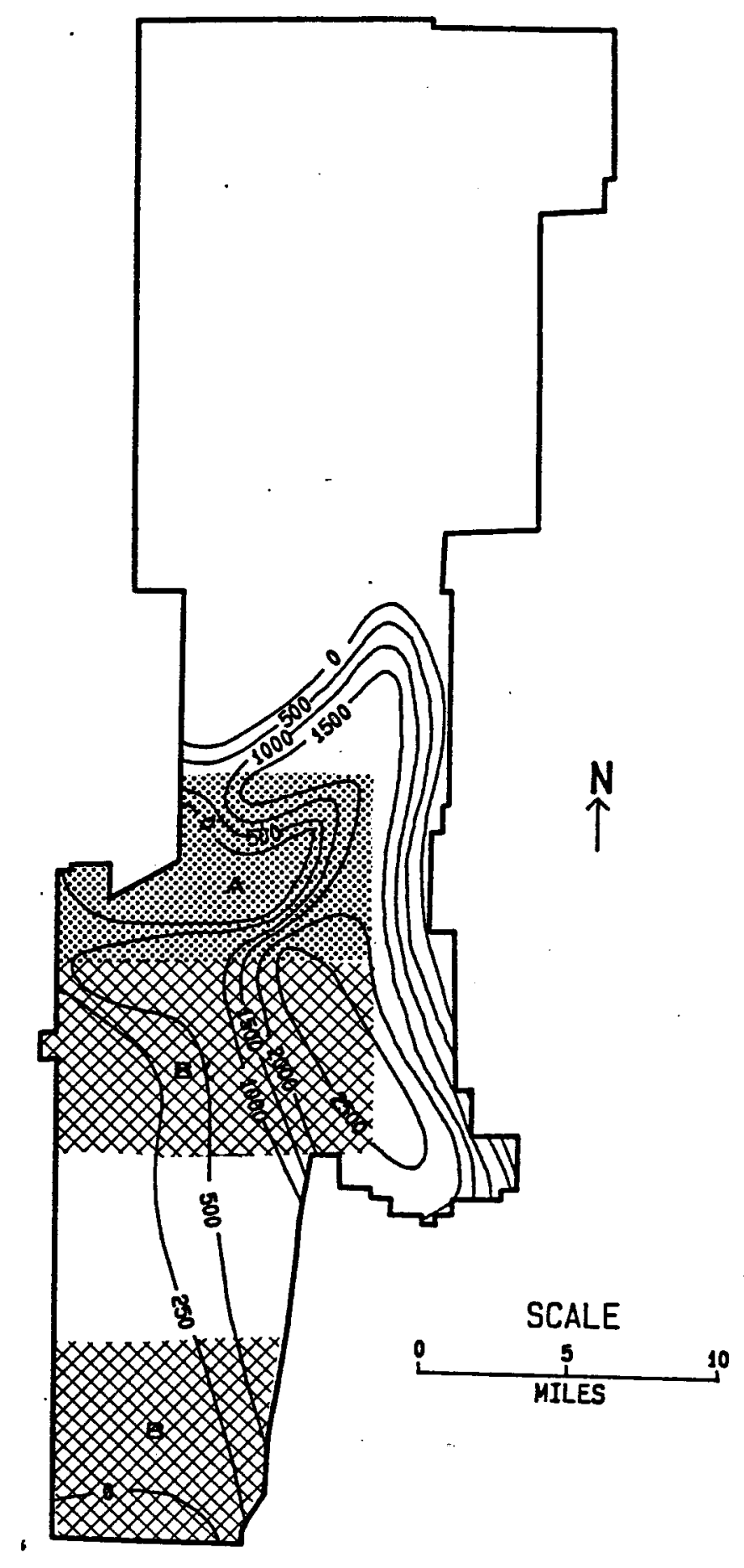

Figure 3-6. Tularosa Basin, saturated thickness (in $\mathrm{ft}$ ) of the moderately saline water zones ( $3-10 \mathrm{~g} / \mathrm{L}$ TDS) within the study area and potential production areas 


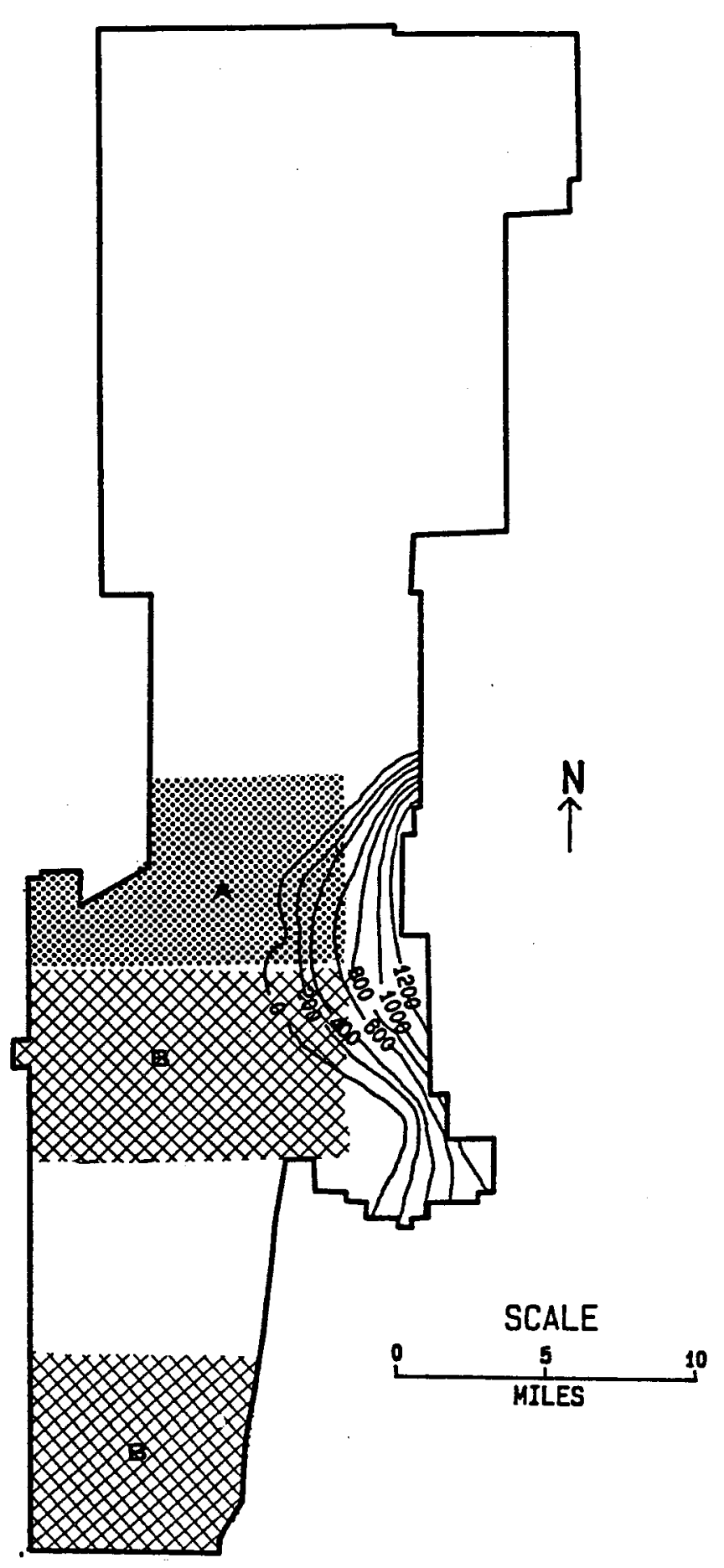

Figure 3-7. Tularosa Basin, saturated thickness (in $\mathrm{ft}$ ) of fresh-water zones within the study area and potential production areas 


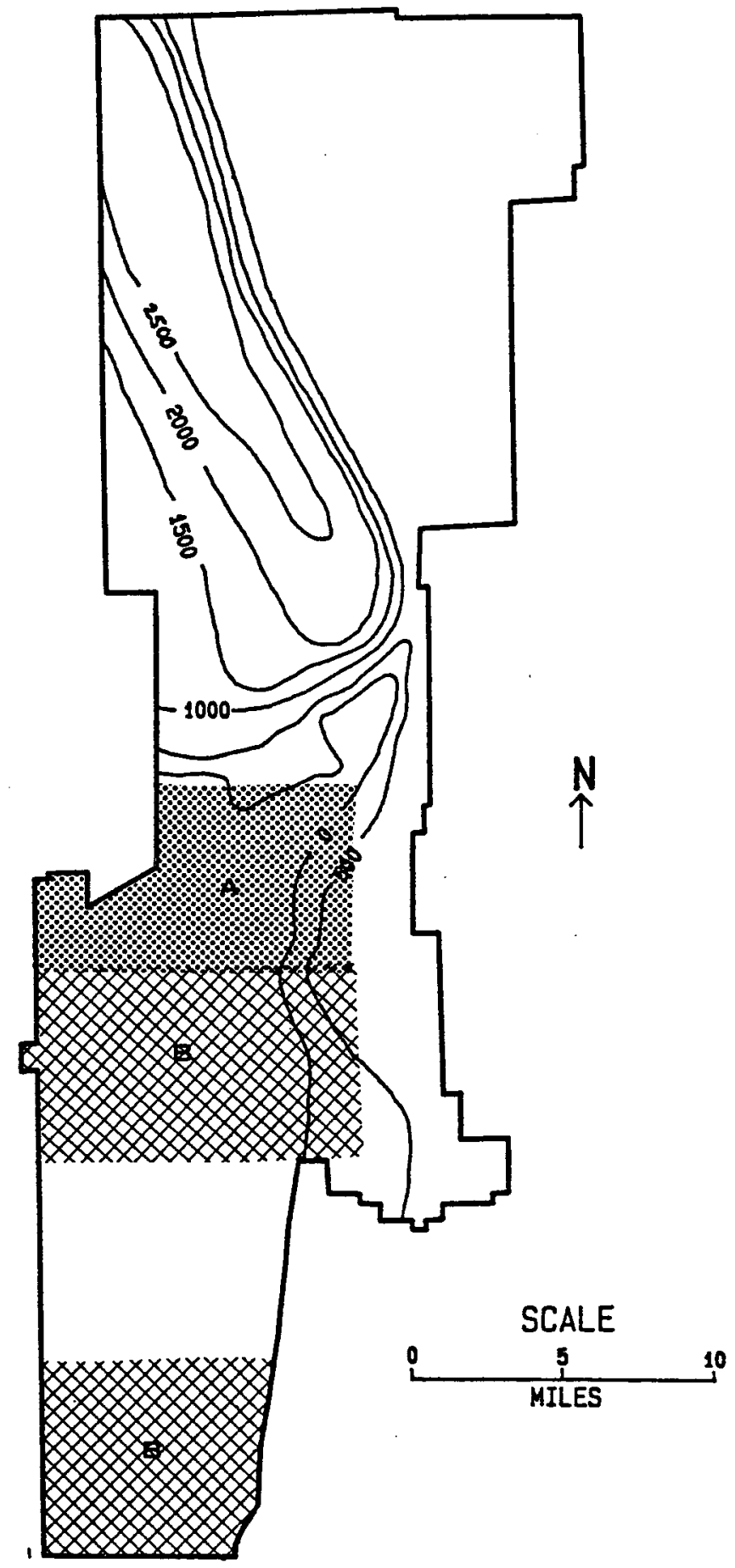

Figure 3-8. Tularosa Basin, saturated thickness (in $\mathrm{ft}$ ) of slightly saline water zones ( $1-3 \mathrm{~g} / \mathrm{L}$ TDS) within the study area and potential production areas 


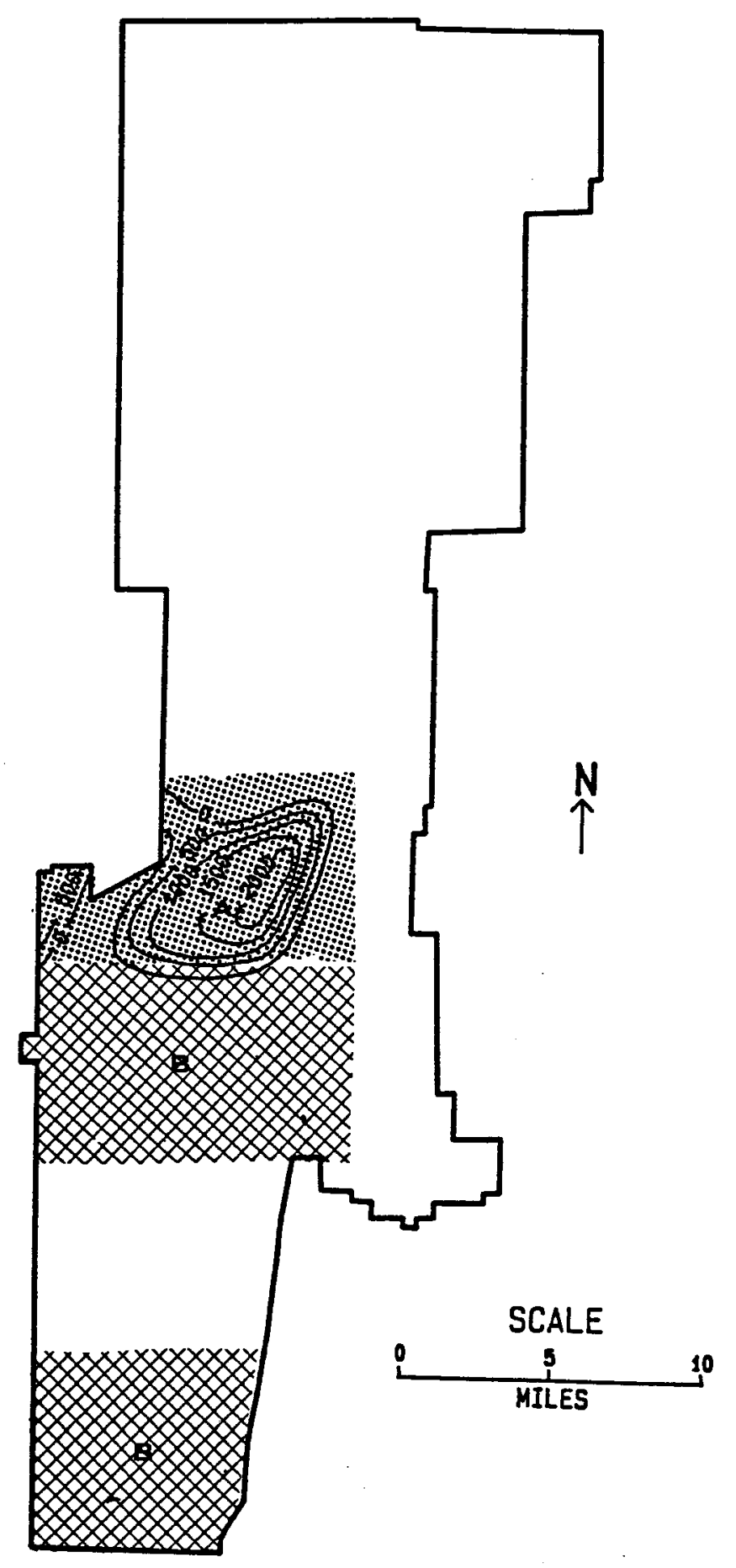

Figure 3-9. Tularosa Basin, saturated thickness (in $\mathrm{ft}$ ) of the very saline water zones (10-35 g/L TDS) within the study area and potential production areas 


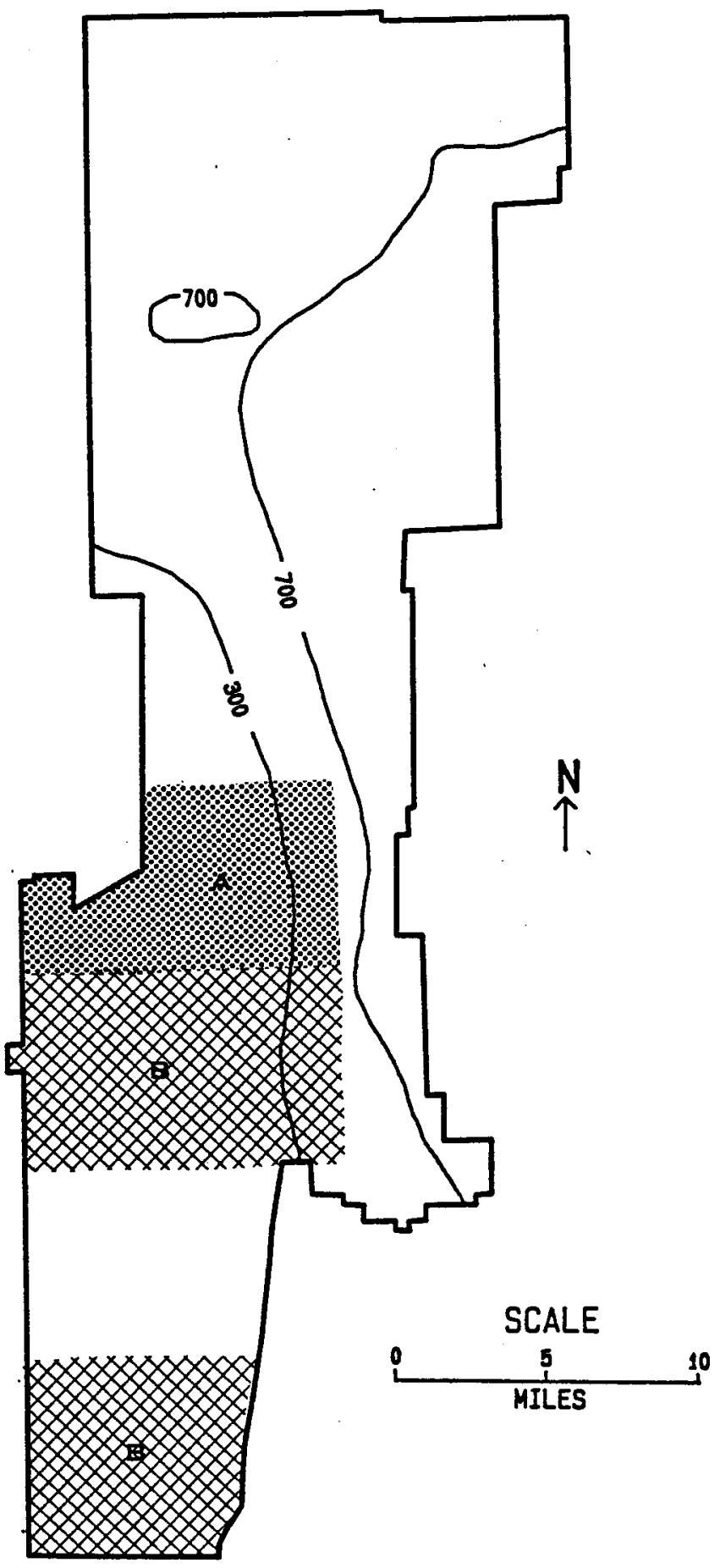

Figure 3-10. Tularosa Basin, potential well-yields (in gpm) within the study area and potential production areas 


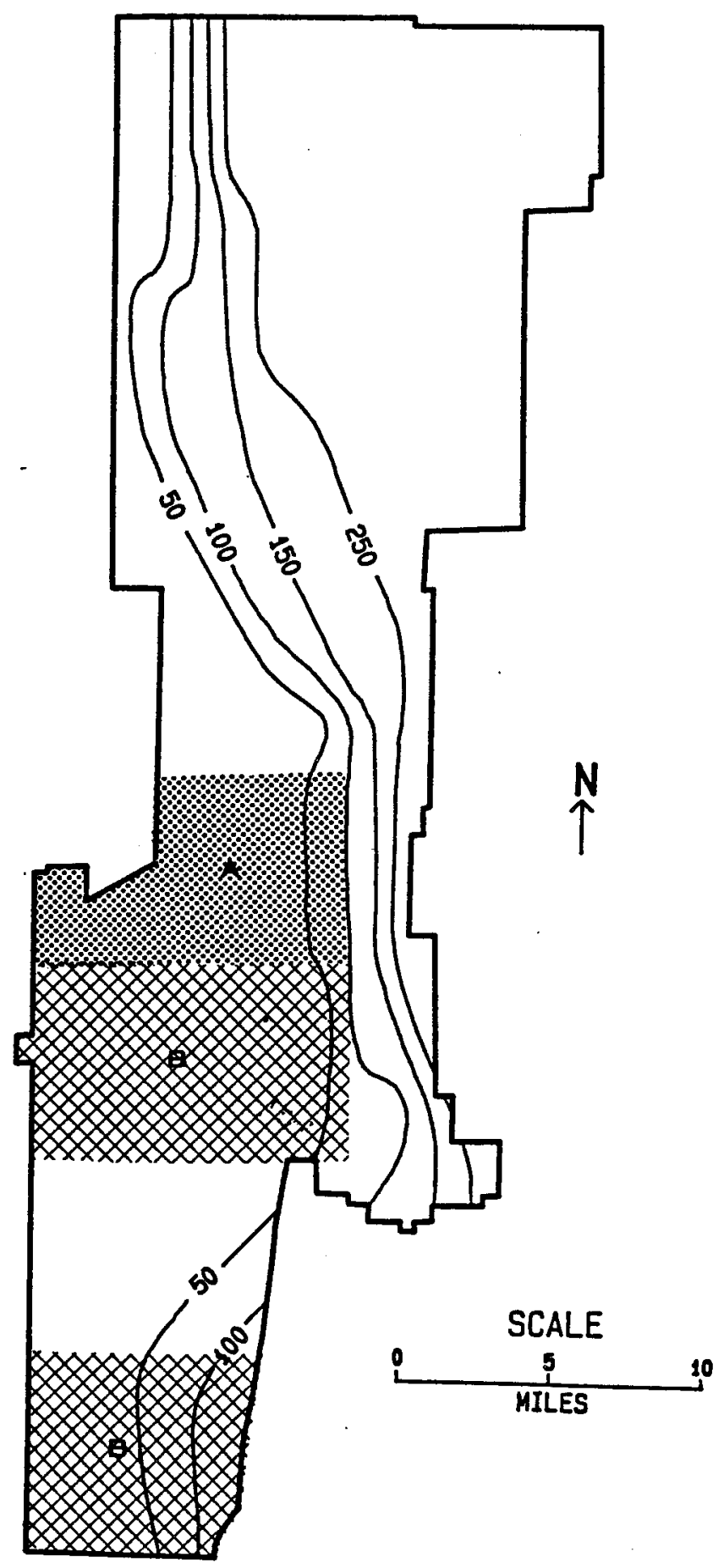

Figure 3-11. Tularosa Basin, depth to groundwater (in $\mathrm{ft}$ ) within the study area and potential production areas 
Table 3-3. Site and Groundwater Characteristics for Potential Production Areas in Tularosa Basin, New Mexico

\begin{tabular}{|c|c|c|}
\hline & \multicolumn{2}{|c|}{ Potential Production Areas } \\
\hline & Site A & Site B \\
\hline \multicolumn{3}{|l|}{ Site Characteristics } \\
\hline Area & $40 \mathrm{mi}^{2}$ & $75 \mathrm{mi}^{2}$ \\
\hline Slope & $<2 \%$ & $<2 \%$ \\
\hline $\begin{array}{c}\text { Ownership } \\
\text { Federal } \\
\text { State } \\
\text { Private }\end{array}$ & $\begin{array}{l}35 \% \\
25 \% \\
40 \%\end{array}$ & $\begin{array}{l}15 \% \\
10 \% \\
75 \%\end{array}$ \\
\hline Growing Season & $200-205$ days & $205-210$ days \\
\hline Evaporation & $\begin{array}{l}70-75 \mathrm{in} \\
178-191 \mathrm{~cm}\end{array}$ & $\begin{array}{l}75-80 \mathrm{in} . \\
191-203 \mathrm{~cm}\end{array}$ \\
\hline \multicolumn{3}{|l|}{ Water Resources } \\
\hline $\begin{array}{l}\text { Depth to } \\
\text { Groundwater }\end{array}$ & $\begin{array}{l}0-50 \mathrm{ft} \\
0-15 \mathrm{~m}\end{array}$ & $\begin{array}{l}0-50 \mathrm{ft} \\
0-15 \mathrm{~m}\end{array}$ \\
\hline $\begin{array}{l}\text { Potential } \\
\text { Well-Yield }\end{array}$ & $\begin{array}{l}\text { up to } 300 \mathrm{gpm} \\
\text { up to } 1135 \mathrm{Lpm}\end{array}$ & $\begin{array}{l}\text { up to } 300 \mathrm{gpm} \\
\text { up to } 1135 \mathrm{Lpm}\end{array}$ \\
\hline Average pH & $7.0-7.6$ & $7.0-7.6$ \\
\hline Estimated Reserves & $384,000-1,280,000$ acre-ft & $720,000-2,400,000$ acre-ft \\
\hline Groundwater Quality & $\begin{array}{c}10,000-35,000 \mathrm{mg} / \mathrm{L} \\
4.74-15.8 \times 10^{1} \mathrm{~L}\end{array}$ & $\begin{array}{l}3,000-10,000 \mathrm{mg} / \mathrm{L} \\
9 / 99=20 / 6 \times 10^{1} \mathrm{~L}\end{array}$ \\
\hline $\begin{array}{l}\text { Ionic Composition } \\
\text { Calcium } \\
\text { Sodium and Potassium } \\
\text { Magnesium } \\
\text { Sulfate } \\
\text { Chlorine } \\
\text { Bicarbonate }\end{array}$ & $\begin{array}{r}50-3100 \mathrm{mg} / \mathrm{L} \\
20-12,600 \mathrm{mg} / \mathrm{L} \\
20-3400 \mathrm{mg} / \mathrm{L} \\
30-9300 \mathrm{mg} / \mathrm{L} \\
30-24,000 \mathrm{mg} / \mathrm{L} \\
20-380 \mathrm{mg} / \mathrm{L}\end{array}$ & $\begin{array}{r}100-950 \mathrm{mg} / \mathrm{L} \\
50-2100 \mathrm{mg} / \mathrm{L} \\
50-1660 \mathrm{mg} / \mathrm{L} \\
300-3100 \mathrm{mg} / \mathrm{L} \\
50-4200 \mathrm{mg} / \mathrm{L} \\
80-250 \mathrm{mg} / \mathrm{L}\end{array}$ \\
\hline
\end{tabular}


The groundwater characteristics for site $B$ are quite similar to those found in site $A$ with the exception of water quality (Table 3-3). The water quality is moderately saline $(3000$ to $10,000 \mathrm{mg} / \mathrm{L}$ TDS) for site $B$ as compared with very saline for site $A$ (Figures 3-8 and 3-9). Therefore, the ionic concentrations are much lower than for waters found in site A. Well-yields for the area are below $300 \mathrm{gpm}$ for the site (Figure 3-10) and the depth to water is $50 \mathrm{ft}$ or less (Figure 3-11). There is virtually no occurrence of fresh water or of water below the $3000 \mathrm{mg} / \mathrm{L}$ TDS level in the area.

\subsubsection{Summary}

When all of the SERI criteria are considered, only two areas in the Tularosa drainage basin were identified as acceptable potential sites for large-scale microalgae production facilities. Approximately $115 \mathrm{mi}^{2}$ were found (just over 73,000 acres) that possess the necessary land and groundwater conditions to meet SERI standards. One exception to this may possibly be the relatively low well-yields that are characteristic of the identified areas. For a 1000 ha ( 2470 acre) facility, low yields may be offset by more wells. A field study is needed to ascertain actual well-yields and to define the allowable spacing between wells. While there are no $\mathrm{pH}$ data available for the potential production area, well data are presented in McLean (1970) for specific ionic composition of groundwater in this area.

\subsection{The Estancia Basin}

\subsubsection{Introduction}

The Estancia Basin is located in central New Mexico and is part of the Central Closed Basin. The basin ends in a series of playa lakes, the largest of which is Laguna del Perro, which has an area of 7 to $8 \mathrm{mi}^{2}$. The total playa area in the valley floor is about $19 \mathrm{mi}^{2}$. The basin is bordered by the Rio Grande Basin to the west and north, the Pecos River Basin to the east, and the Tularosa Basin to the south (Figure 3-12). The area of the Estancia Basin is $2220 \mathrm{mi}^{2}$ (Bureau of Reclamation 1976). Elevations within the basin range from $6000 \mathrm{ft}$ in the basin floor to more than $10,000 \mathrm{ft}$ in the western mountains (Smith 1957).

\subsubsection{Setting and Climatic Characteristics}

The major towns in the basin are Estancia, Moriarty, and Mountainair. They are all on the east side of the basin and are relatively small. They make up the bulk of the population in the basin, which is approximately 10,000 persons (Diemer and Morrison 1984). A major interstate, $\mathrm{I}-40$, bisects the northern portion of Torrance County through the town of Moriarty.

The climate in the Estancia Basin is typical of the semiarid regions of the southwestern United States. Table 3-4 presents a summary of climatic information for the basin. The mean annual precipitation averages 12.5 in. in the central portion of the basin. Precipitation on the slopes of the surrounding mountains produce intermittent stream runoff that drains toward the center of the basin or moves as groundwater flow through the alluvial fans as interflow. The intense summer thunderstorms produce high runoff of short duration, most of which flows into the playas or alkali flats and evaporates. Average temperatures in the basin range from an average of about $50^{\circ} \mathrm{F}$ in the central portion of the basin to about $40^{\circ} \mathrm{F}$ in the bordering mountains. 


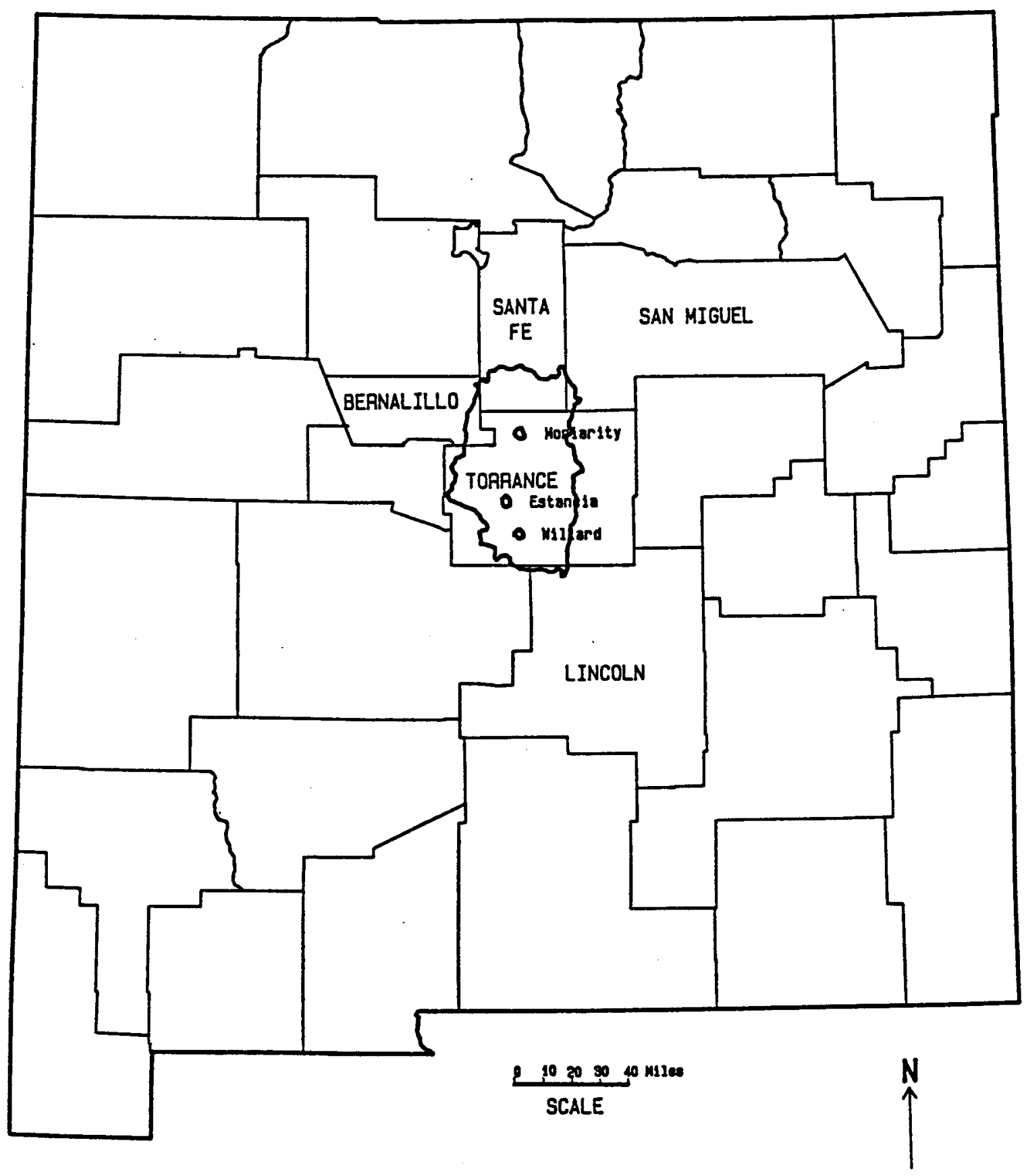

Figure 3-12. Location of the Estancia Basin, New Mexico 
Table 3-4. Selected Climatic Data for Stations within the Estancia Basin, New Mexico

\begin{tabular}{lc}
\hline \multicolumn{1}{c}{ McIntosh } & \\
\hline $\begin{array}{l}\text { Elevation } \\
\text { (above msl) }\end{array}$ & $6250 \mathrm{ft}$ \\
$\begin{array}{c}\text { Average days } \\
\text { above } 32^{\circ} \mathrm{F}\end{array}$ & 133 days \\
$\begin{array}{c}\text { Average frost- } \\
\text { free period }\end{array}$ & $\begin{array}{c}\text { May } 19- \\
\text { September } 28\end{array}$ \\
$\begin{array}{l}\text { Mean annual } \\
\text { precipitation }\end{array}$ & 12.5 in. \\
$\begin{array}{l}\text { Maximum mean } \\
\text { monthly air } \\
\text { temperature }\end{array}$ & $\begin{array}{c}\text { July } \\
\text { Minimum mean } \\
\text { monthly air } \\
\text { temperature }\end{array}$ \\
$\begin{array}{l}\text { Average annual } \\
\text { air temperature }\end{array}$ & $\begin{array}{c}\text { January } \\
30.2^{\circ} \mathrm{F}\end{array}$ \\
\hline $\begin{array}{l}\text { Source: New Mexico State Engineer } \\
\text { 1975 }\end{array}$ & $50.2^{\circ} \mathrm{F}$ \\
\hline
\end{tabular}

Basic climate data suggest that, with no major surface water sources and evaporation greater than precipitation, the Estancia Basin is not recharged -ignificantly. Rather, it is mined for groundwater. Irrigated agriculture has produced declines in the groundwater levels in these areas of most intense pumping, and as in the Tularosa Basin, water withdrawal for microalgae production would be considered water mining. Smith (1957) estimates the average annual evaporative losses from the playa lakes to be about 50,000 acre-ft; this may also be assumed to be the inflow to the valley floor and the volume of saline water that is available for use.

The major crops grown in the Estancia Basin are corn, wheat, potatoes, alfalfa, and planted pasture (Lansford 1985). The majority of irrigated agriculture in the basin exists in an area between the western mountains and the alkali flats in the basin floor. The agriculture exists on a north-to-south axis from north of Moriarty to south of Willard following New Mexico Highway 41. Water quality and well-yields of the hydrogeologic formations are most suited to irrigated agriculture in these areas. 


\subsubsection{Study Area}

For the purpose of siting large-scale microalgae production facilities within the Estancia Basin, a limited study area was identified (Figure 3-13). The borders of this area are T.10 N. on the north, T.2 N. on the south, R.8 E. on the west, and R.11 E. on the east, inclusive. This study area lies north and east of Moriarty on the north to about $15 \mathrm{mi}$ south of Willard on the south. It was derived using natural boundaries, geologic formations, political boundaries, and slope criteria. North of the area, sites are limited by slope as the drainage basin merges with plateau lands. In the east and west of the basin, the Pedernal Hills and Manzano Mountains, respectively, produce slopes greater than $2 \%$. The selection of the southern boundary of the area was made based on the existence of mesa lands and on federal ownership in the Cibola National Forest. Surface waters from the west, north, and east drain into the central valley that terminates at the southern end of the long playa lake of Laguna del Perro.

\subsubsection{Land Ownership and Slope}

Figure 3-14 presents land ownership within the Estancia Basin and Figure 3-15 shows the areas with the required slope of less than $2 \%$. Ownership was defined as $15 \%$ federal $25 \%$ state, and $60 \%$ private. A further breakdown of ownership would require a detailed field survey. Land use was determined to be closely tied to land ownership within the study area. The major land use in the study area is livestock grazing.

\subsubsection{Water Resources}

Little information is available on the volume of saline water in the basin, the thickness of the saline alluvial aquifer, or the yield of wells that produce solely from the saline zone.

Basic data for the groundwater resources of the Estancia Basin were taken from Smith (1957) and the New Mexico state engineer (1979). Additional well data were obtained from the USGS.

The principal geologic zones in the study area are presented in Figure 3-16. This figure was adapted from Smith (1957). The sharp boundaries between zones are approximations based on geological changes and groundwater of different quality and of different depths. Zones $\mathrm{H}$ and $\mathrm{B}$ denote the Quaternary and Tertiary valley-fill, which comprise the principal basin aquifer. Zone $\mathrm{H}$ has depths to water that range from 0 to $250 \mathrm{ft}$, potential well-yields of more than $1000 \mathrm{gpm}$, and water quality that is satisfactory for domestic use and irrigated agriculture. This is, coincidentally, the area where the majority of the irrigated agriculture in the Estancia Valley exists. Zone B has depths to water that range from 0 to $120 \mathrm{ft}$, potential well-yields from the better-quality areas of more than $1000 \mathrm{gpm}$, and shallow water quality that is generally unsatisfactory for domestic use and irrigation. There are large areas of evaporative lakes or playas in zone B, with the poorest quality water found in shallow valley alluvia below these playas.

Zones $\mathrm{A}$ and $\mathrm{C}$ denote areas in which the Glorieta member of the San Andres Formation is the principal aquifer. Zone A has depths to water that range from 25 to $100 \mathrm{ft}$, potential well-yields of more than $1000 \mathrm{gpm}$, and water quality that ranges from satisfactory to marginal for domestic and agricultural uses. Zone $C$ has depths to water that range from 30 to $200 \mathrm{ft}$, and potential yields and water quality that are generally unsatisfactory for domestic use and irrigated agriculture. 


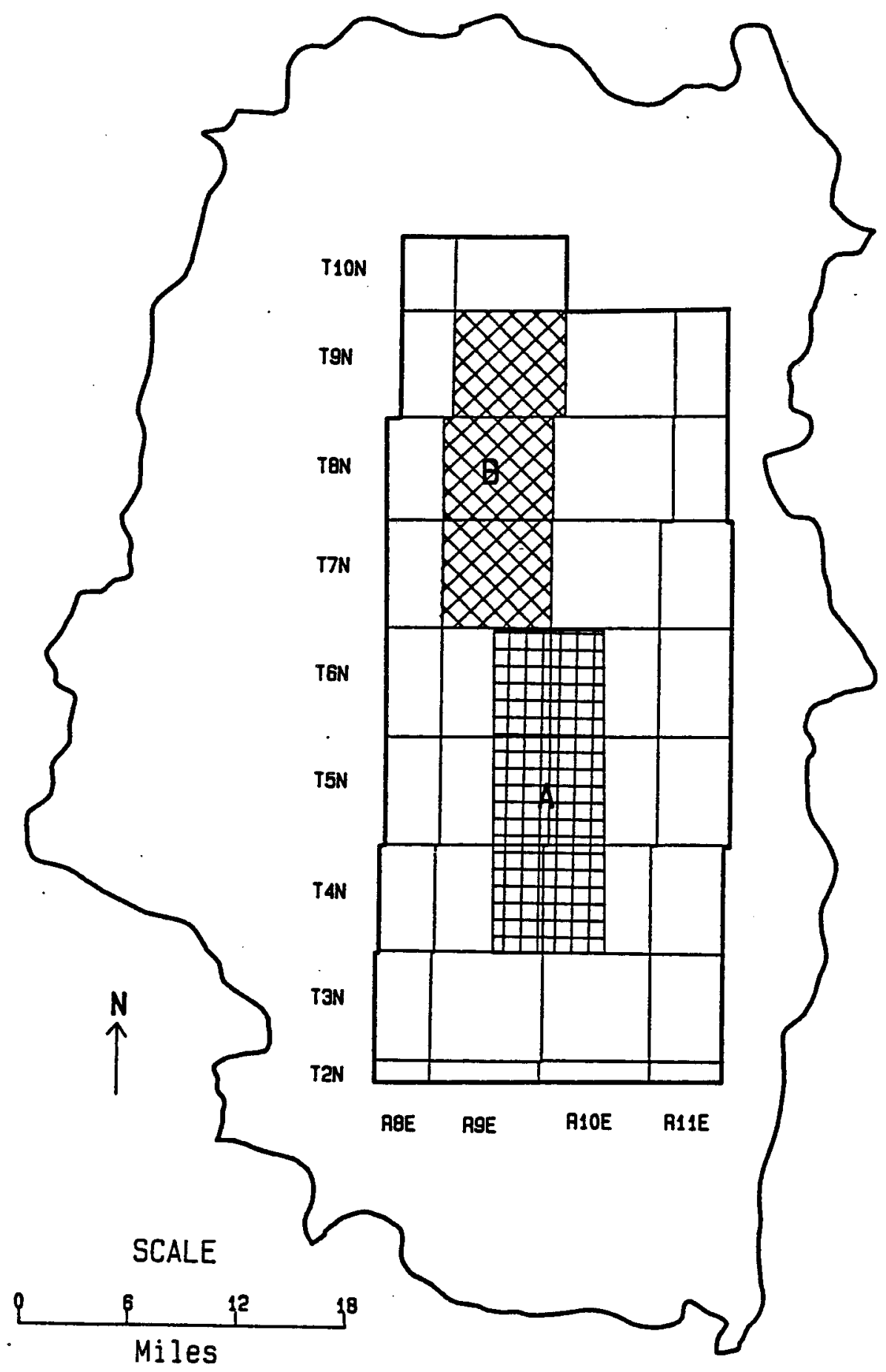

Figure 3-13. Study area and potential production areas in the Estancia Basin, New Mexico 


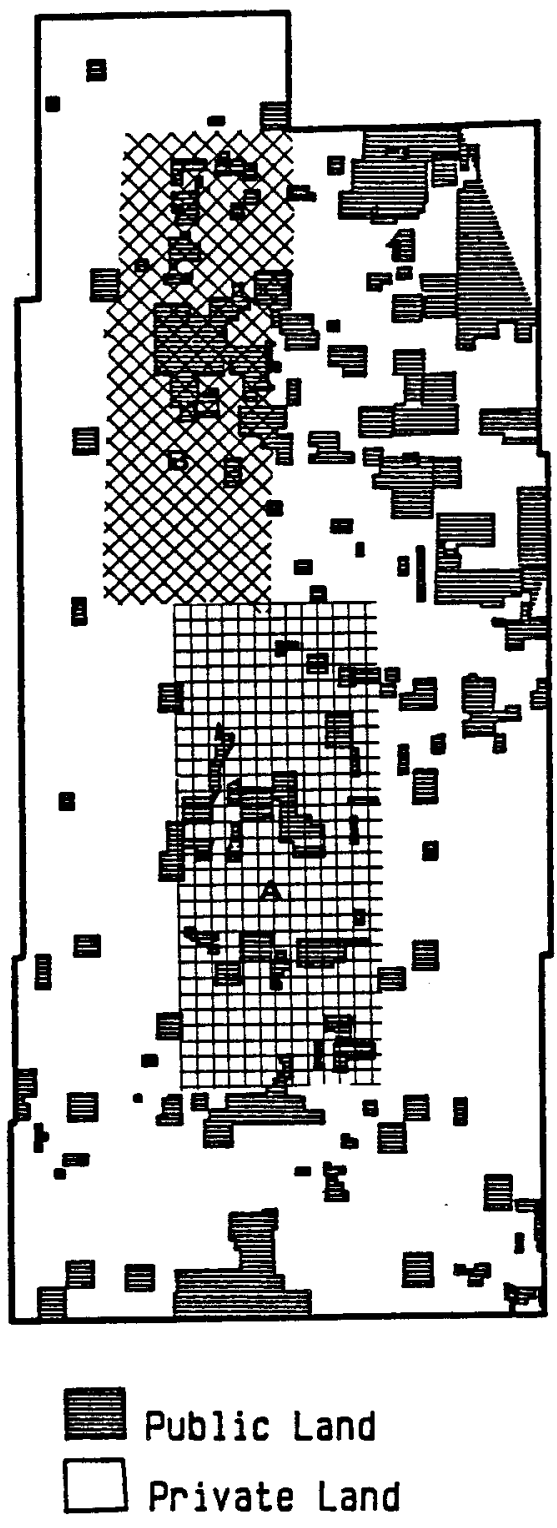

SCALE

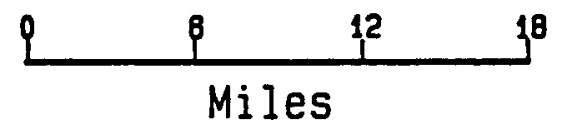

Figure 3-14. Estancia Basin, land ownership within the study area and potential production areas 


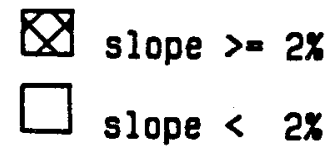

$\uparrow$
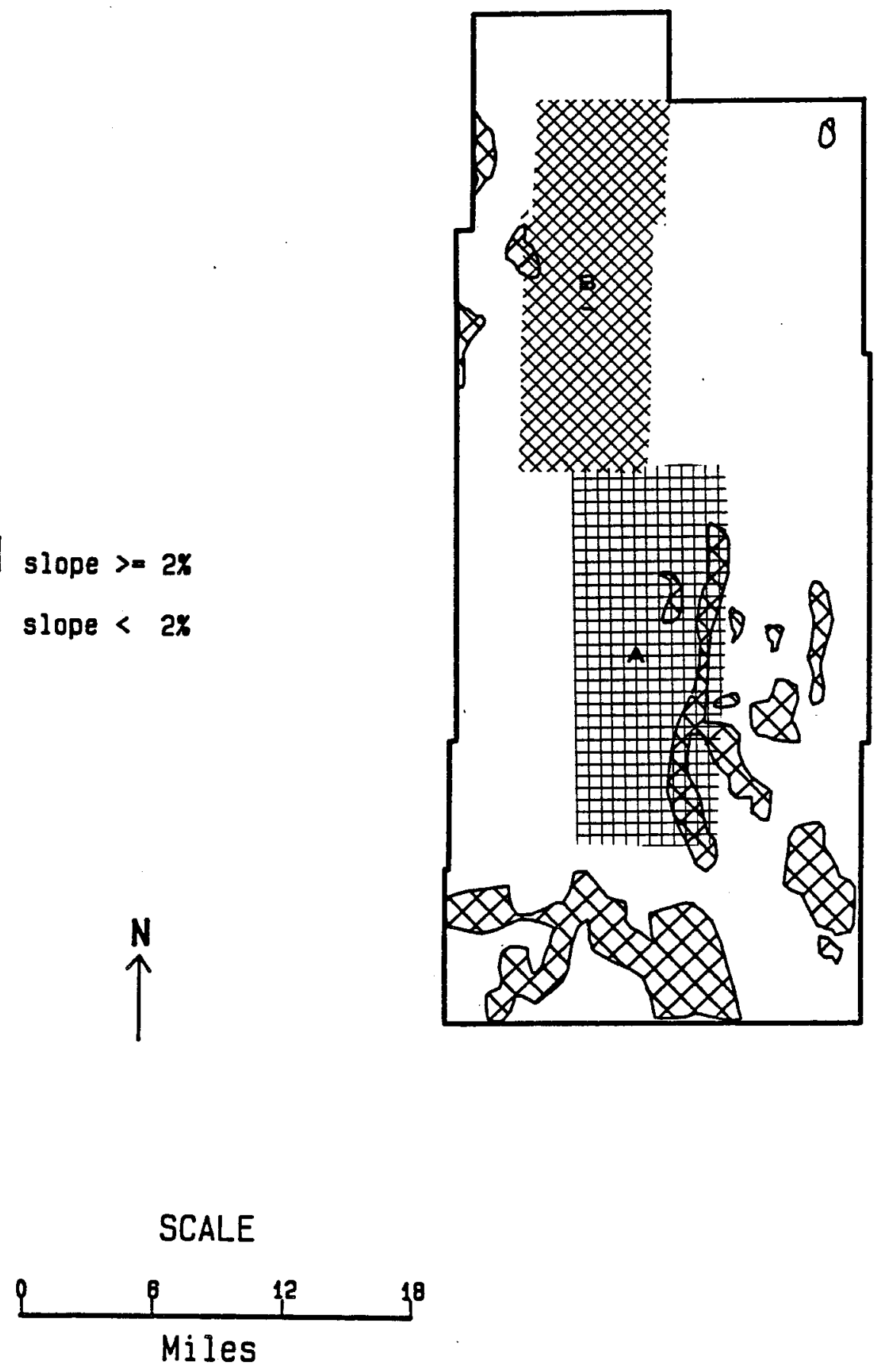

Figure 3-15. Estancia Basin, places with land slopes that exceed 2\% within the study area and potential production areas 


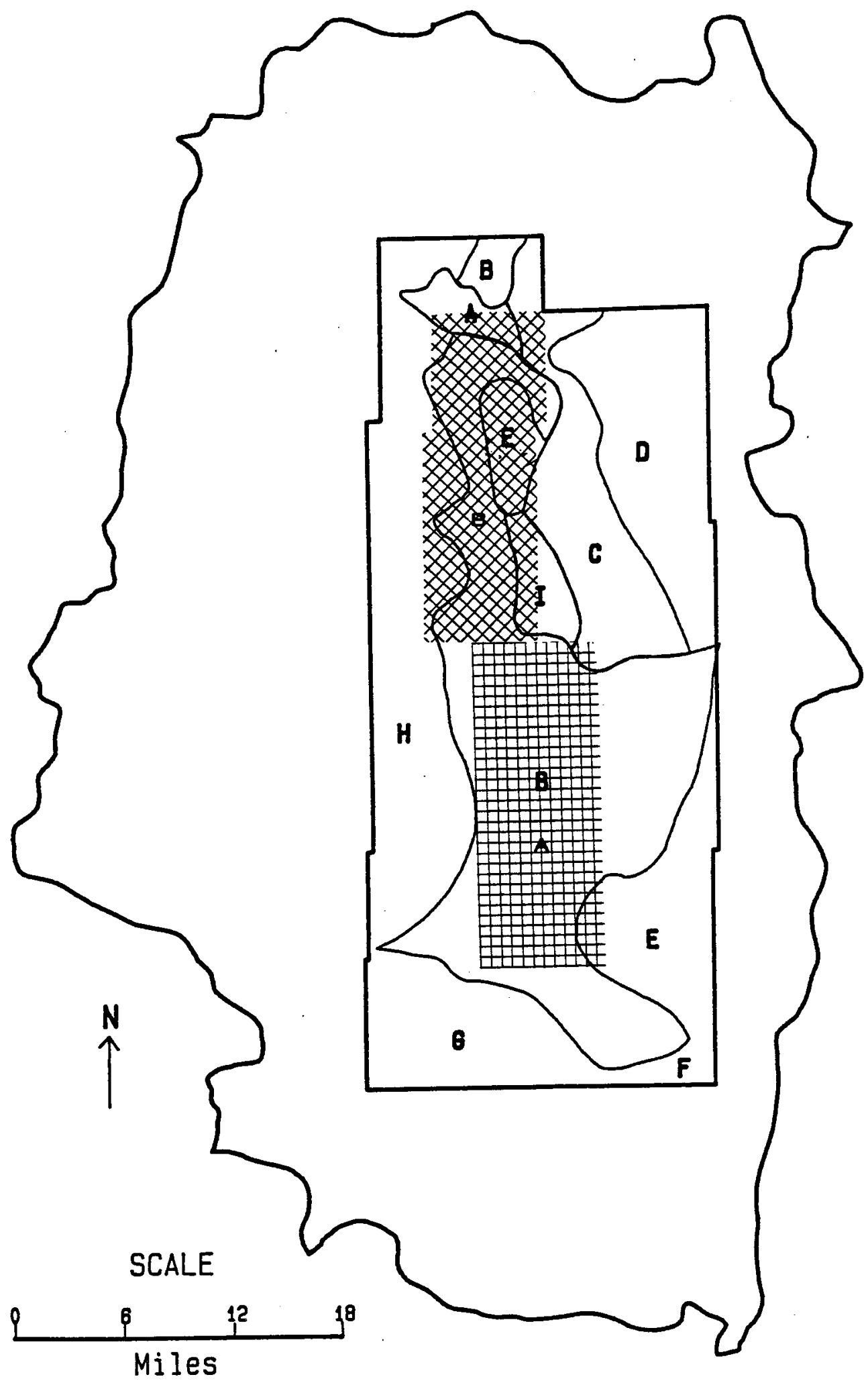

Figure 3-16. Estancia Basin, geologic zones within the study area and potential production areas 
Zones F, G, I, and D denote areas in which the Yeso Formation is the principal aquifer (Figure 3-16). Zone $F$ has depths to water that range from 15 to $325 \mathrm{ft}$, with quality unsuitable for domestic and irrigated agricultural uses. Zone G has depths to water of 175 to $750 \mathrm{ft}$, with quality unsatisfactory for domestic and agricultural purposes. Zone I has depths to water that range from 20 to $50 \mathrm{ft}$, potential well-yields recorded as high as $2000 \mathrm{gpm}$, and chemical quality that is unsatisfactory for domestic and irrigated agricultural uses. Zone $D$ has depth to water of 40 to $625 \mathrm{ft}$, with marginal water quality for domestic and agricultural uses. Zone $\mathrm{E}$ contains areas in which the principal aquifer is of Precambrian rocks. The depth to groundwater of this geologic zone is 30 to $375 \mathrm{ft}$, and the water quality is satisfactory to marginal for domestic uses and irrigated agriculture. Well-yields are likely to be low in this zone, with a maximum yield of about $100 \mathrm{gpm}$.

\subsubsection{Groundwater Quality}

Figure 3-17 presents the groundwater quality in the Estancia Basin with the TDS content measured in specific conductance (micromhos per $\mathrm{cm}$ at $25^{\circ} \mathrm{C}$ ). The general trend of this characteristic is the same as in the Tularosa Basin; the higher quality water is at the perimeter of the area of interest and the lower quality water is in the valley floor of the basin. There is one major difference, however; the poorer quality water lies above the better quality water. The TDS in the Estancia Basin range from 500 to $1000 \mathrm{mg} / \mathrm{L}$ at the western edge to $10,000 \mathrm{mg} / \mathrm{L}$ at the eastern edge. In the central valley floor, TDS range from 1500 to $3000 \mathrm{mg} / \mathrm{L}$.

Water quality is also an unknown in the shallow upper-zone of the alluvial material in the southern end of the valley. Many of the wells sampled in zone B (Figure 3-16) are likely to penetrate both the more saline upper layer and the better-quality water below and may not reflect the water quality at the surface in the playas. Based on a few available samples from wells in the playa lake area, the TDS content of the upper saline zone is probably about 5000 to $6000 \mathrm{mg} / \mathrm{L}$. The volume of the saline water in storage can only be estimated. Assuming a 100- $\mathrm{m}^{2}$ area, a saline zone thickness of 30 to $80 \mathrm{ft}$ (Smith 1957), and a storage coefficient of $10 \%$, the recoverable volume of poor quality water in storage would be about 192,000 to 512,000 acre-ft.

\subsubsection{Potential Production Areas}

The geology of the valley floor makes the Estancia drainage basin a prime location for microalgae facilities. There are a series of playas or dry alkali lake beds on a north-south axis in the southern end of the drainage that meet all of the SERI criteria for siting a microalgae production facility.

Two connecting areas within the Estancia Basin met the SERI criteria for the location of a microalgae production facility, with the possible exception of growing seasons (Figure 3-13). The average growing season of 140 to 160 days may be a major limitation for these sites (Table 3-5). Groundwater quality, depth, potential well-yields, and land slope were identified and met SERI standards.

\subsubsection{Site A}

The $80-\mathrm{m}^{2}$ area lies immediately east of Estancia trending north to about $5 \mathrm{mi}$ south of Willard (Figure 3-13). The area is approximately $6 \mathrm{mi}$ wide. The best site for the location of a facility is near the existing playa lakes because the water quality is poorest and surface flows terminate at these alkali flats and provide groundwater recharge. The land 


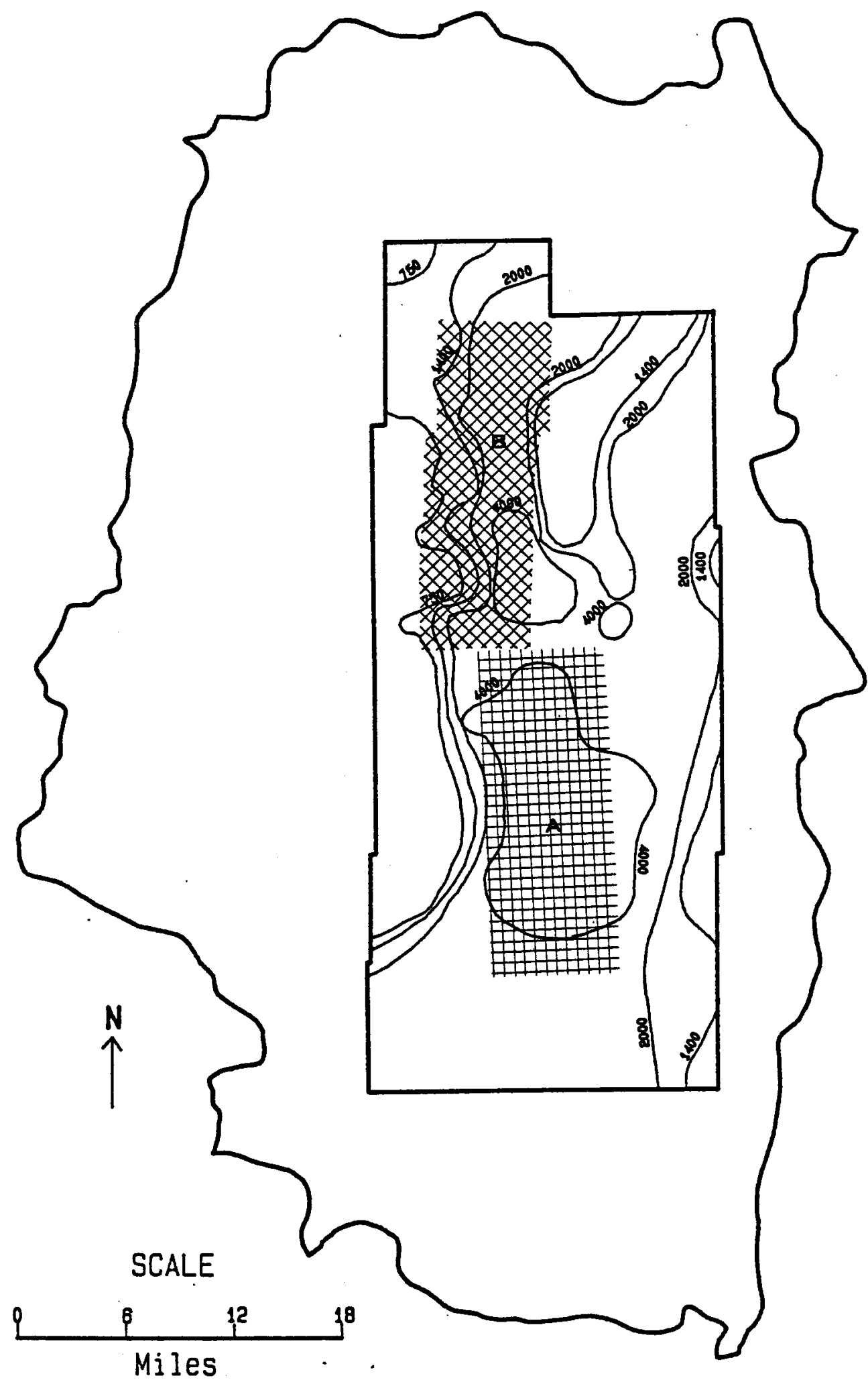

Figure 3-17. Estancia Basin, water quality (specific conductance in micromhos per $\mathrm{cm}$ at $25^{\circ} \mathrm{C}$ ) within the study area and potential production areas 
Table 3-5. Site and Groundwater Characteristics for Potential Production Areas in Estancia Basin, New Mexico

Potential Production Areas

Site ASite B

\section{Site Characteristics}

Area

Slope

Ownership

Federal

State

Private

Growing Season

Evaporation

Water Resources

Depth to

Groundwater

Potential

Well-Yield

Average $\mathrm{pH}$

Estimated Reserves

Groundwater Quality

Ionic Composition

Calcium

Sodium and Potassium

Magnesium

Sulfates

Chlorine

Bicarbonate
$0-30 \mathrm{ft}$

0-9 m0-9 m

up to $1000 \mathrm{gpm}$

up to $3790 \mathrm{Lpm}$

$7.3-7.8$

155,000-615,000 acre-ft

$$
1.91-7.59 \times 10^{1} \mathrm{~L}
$$

$3000-5500 \mathrm{mg} / \mathrm{L}$

$$
50-640 \mathrm{mg} / \mathrm{L}
$$

$20-750 \mathrm{mg} / \mathrm{L}$

$40-480 \mathrm{mg} / \mathrm{L}$

$120-3200 \mathrm{mg} / \mathrm{L}$

$10-1440 \mathrm{mg} / \mathrm{L}$

$65-900 \mathrm{mg} / \mathrm{L}$
140-150 days

45-50 in.

$114-127 \mathrm{~cm}$
$0-30 \mathrm{ft}$

up to $1000 \mathrm{gpm}$

up to $3790 \mathrm{Lpm}$

$$
\text { 7.3-7.8 }
$$

173,000-692,000 acre-ft $2.13-8.54 \times 10^{1 I_{L}}$

$1500-3000 \mathrm{mg} / \mathrm{L}$

$40-290 \mathrm{mg} / \mathrm{L}$ $30-210 \mathrm{mg} / \mathrm{L}$ $20-180 \mathrm{mg} / \mathrm{L}$ $60-1050 \mathrm{mg} / \mathrm{L}$ $30-4900 \mathrm{mg} / \mathrm{L}$ $190-350 \mathrm{mg} / \mathrm{L}$ 
ownership pattern is approximately $15 \%$ federal, $25 \%$ state, and $60 \%$ privately owned lands. The growing season ranges from 150 to 160 days (Table 3-5).

Groundwater quality in the shallow zone is expected to have TDS of $3000 \mathrm{mg} / \mathrm{L}$ or more (Table 3-5). The thickness of this poor quality alluvial zone varies from 30- to $80-\mathrm{ft}$ thick in the center of the playa portion of the basin (Smith 1957). However, there is groundwater with less than $3000 \mathrm{mg} / \mathrm{L}$ TDS below the upper zone.

Potential well-yields from this saline zone are not well known, but could be as high as $1000 \mathrm{gpm}$. Depth to groundwater ranges from 0 to $30 \mathrm{ft}$. Actual well-yields cannot be predicted without field tests. If well-yields are high, a minimum of four wells would produce the SERI requirement of at least 4 million gpd. Approximately 13 wells would be required to meet the SERI criteria for areas with a daily production of 13 million gpd.

A range of possible reserves was estimated for the $80-\mathrm{m}^{2}$ surface area, assuming a saturated thickness of 30 to $80 \mathrm{ft}$ and a storage coefficient of $10 \%$ to $15 \%$. The estimated recoverable volume of poor quality water in storage would be about 155,000 to 615,000 acre-ft. Groundwater recharge occurs primarily from precipitation and runoff because there are no major surface water sources.

The $\mathrm{pH}$ of waters in the basin were estimated to range from 7.3 to 7.8 with some outliers. The specific ions likely to be found in the more saline waters in the valley fill immediately below a playa are calcium, magnesium, sodium, chlorides, sulfates, and bicarbonates (Table 3-5).

\subsubsection{Site B}

A second, large area $\left(90 \mathrm{mi}^{2}\right)$ appears to generally meet the criteria except for groundwater quality and the growing season of 140 to 150 days (Table 3-5). This area is east of Highway 41 between Moriarty and Estancia (Figure 3-13). The width of this tract is approximately $5 \mathrm{mi}$. The slope criteria of $2 \%$ is met and ownership patterns approximate the following: $60 \%$ private, $10 \%$ federal, and $30 \%$ state.

The water resource characteristics in site B are almost identical to those found in site A, with the exception of water quality (Table 3-5). The TDS in the well samples runs from 1500 to $3000 \mathrm{mg} / \mathrm{h}$, which was classified slightly saline. Throughout this site, poorer quality water is believed to overlie better quality water. The depths to groundwater for poorer quality waters range from 0 to $80 \mathrm{ft}$. The saturated thickness of the relatively poorer quality upper-zone is not known, nor are the well-yields. Water quality in the upper-zone is not known with sufficient specificity to accept or reject the area.

Because the water quality in this upper-zone is likely to be classed as slightly saline and is potentially useable for irrigated agriculture, there may be legal challenges and opposition to its use for microalgae culture. The very short growing season combined with slightly saline groundwater would, in all likelihood, eliminate this site from consideration.

\subsubsection{Summary}

The geology of the valley floor makes the Estancia drainage a prime location for microalgae facilities. Two connecting areas within the Estancia Basin meet all of the SERI criteria for potential location of microalgae production facilities. These locations have been designated as Potential Production Areas and encompass approximately $170 \mathrm{mi}^{2}$. 
Groundwater quality, depth, potential well-yields, and land slope were identified and found to meet SERI standards, with the exception of the growing season, which may be too short. The larger of the two areas may not be acceptable because the groundwater resource is classified as being only slightly saline. Owners of existing water rights in the basin may oppose the use of this water for microalgae culture and claim that new appropriations of groundwater will impair existing rights.

There are a series of playas or dry alkali lake beds on a north-south axis in the smaller of these two areas. This may be one of the best areas in New Mexico for locating a 1000 ha ( 2470 acre) microalgae production facility.

\subsection{The Crow Flats Area}

\subsubsection{Introduction}

The Crow Flats area in south-central New Mexico is part of the larger Salt Basin (Figure 3-18). Crow Flats is an area within the Salt Flats Basin as defined by the New Mexico state engineer. The Salt Flats Basin is bordered by the Tularosa Basin on the west, the Pecos River Basin on the north and east, and the state of Texas on the south and has an area of $2370 \mathrm{mi}^{2}$ (Bureau of Reclamation 1976). The vast majority of the area is located within Otero County and very small sections of the basin are located in Chaves and Eddy counties (Figure 3-18). Altitudes range from $3000 \mathrm{ft}$ near the alkali flats in the southern end of the basin to approximately $4500 \mathrm{ft}$ in the surrounding hills (Bjorklund 1957).

\subsubsection{Setting and Climatic Characteristics}

The climate of the Crow Flats Basin is similar to that of the southern end of the Tularosa Basin around the city of Orogrande (Table 3-6). Mean annual precipitation is low and mean annual temperature is approximately $78^{\circ} \mathrm{F}$. As in the Tularosa Basin, intermittent stream runoff drains from surrounding mountains to the alkali flats in the center of the basin.

The majority of the irrigated agriculture in the basin is located along the New MexicoTexas border. The major city in the area is Dell City, Texas, and access to the area is via U.S. Highway 180 from El Paso, Texas. There is an area of approximately $650 \mathrm{mi}^{2}$ that runs north-south through the eastern edge of the basin where well-yields and groundwater quality are suitable to marginally acceptable for irrigated agriculture.

\subsubsection{Study Area}

A limited study area within the Crow Flats area has been identified for the purpose of locating a microalgae production facility. This area lies in the southeast portion of Otero County and is presented in Figure 3-19. The borders of the area are T.21 S. on the north, T.26 S. on the south (New Mexico-Texas state line), R.16 E. on the west, and R.19 E. on the east, inclusive.

\subsubsection{Land Ownership and Slope}

The SERI slope and ownership criteria were also used to define the study area (Figures 3-20 and 3-21). North and east of the area of interest, slopes greater than 2\% exist near the Guadalupe Mountains. Potential sites for microalgae production facilities 


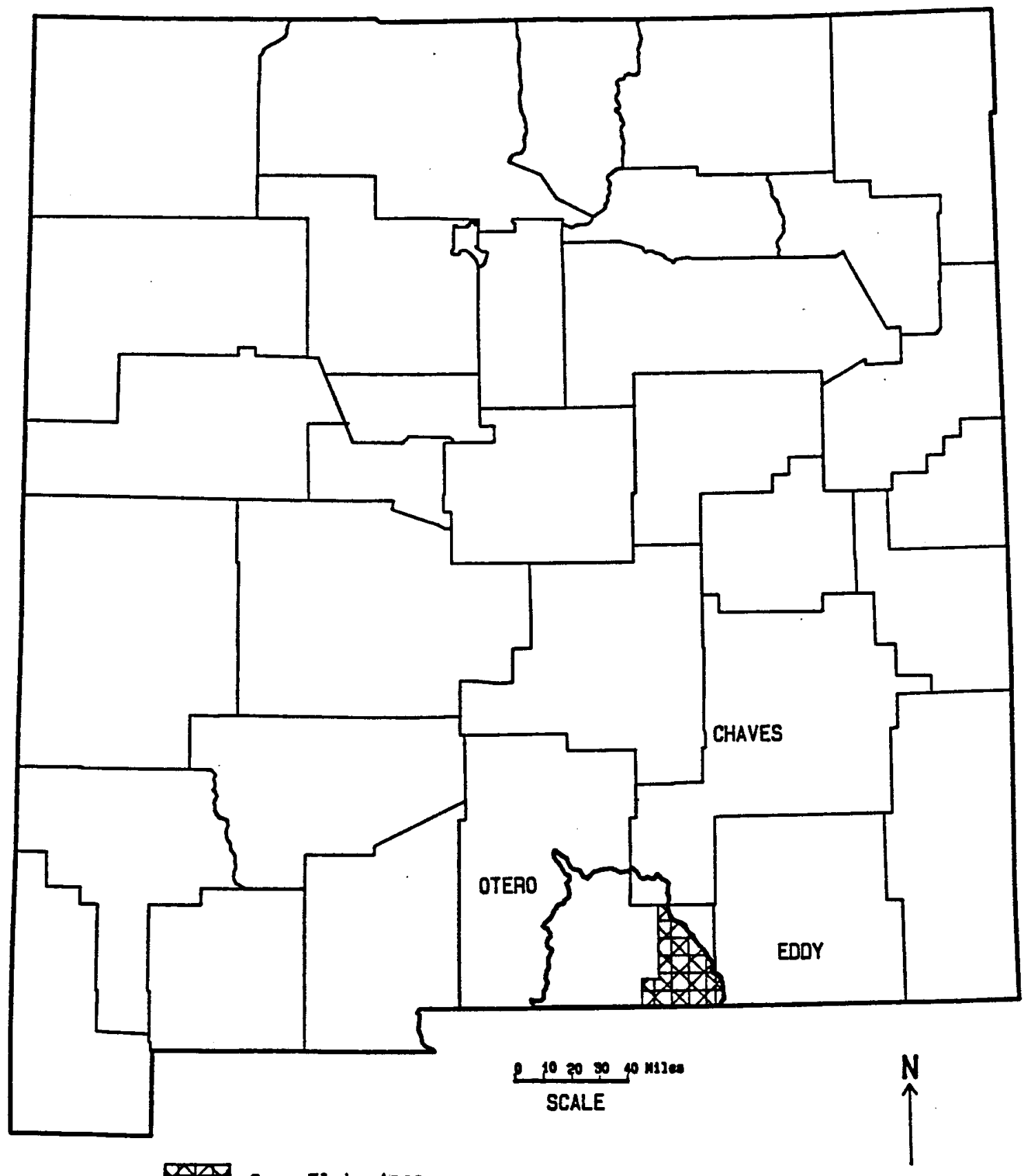

Figure 3-18. Location of the Salt Basin and the Crow Flats Area, New Mexico Source: Bureau of Reclamation 1976 
Table 3-6. Selected Climatic Data for Stations within the Crow Flats Basin, New Mexico

\begin{tabular}{lc}
\hline & $\begin{array}{c}\text { Dell City } \\
\text { Texas }\end{array}$ \\
\hline $\begin{array}{l}\text { Elevation } \\
\text { (above MSL) }\end{array}$ & $3770 \mathrm{ft}$ \\
$\begin{array}{l}\text { Average days } \\
\text { above } 32^{\circ} \mathrm{F}\end{array}$ & 365 days \\
$\begin{array}{l}\text { Average frost- } \\
\text { free period }\end{array}$ & -- \\
$\begin{array}{l}\text { Mean annual } \\
\text { precipitation }\end{array}$ & $2.1^{\mathrm{in} .}$ \\
$\begin{array}{l}\text { Maximum mean } \\
\text { monthly air } \\
\text { temperature }\end{array}$ & \\
$\begin{array}{l}\text { Minimum mean } \\
\text { monthly air } \\
\text { temperature }\end{array}$ & $\mathrm{July}-93.3^{\circ} \mathrm{F}$ \\
$\begin{array}{l}\text { Average annual } \\
\text { air temperature }\end{array}$ & $62.8^{\circ} \mathrm{F}$ \\
\hline
\end{tabular}

Source: U.S. Department of Commerce 1986 


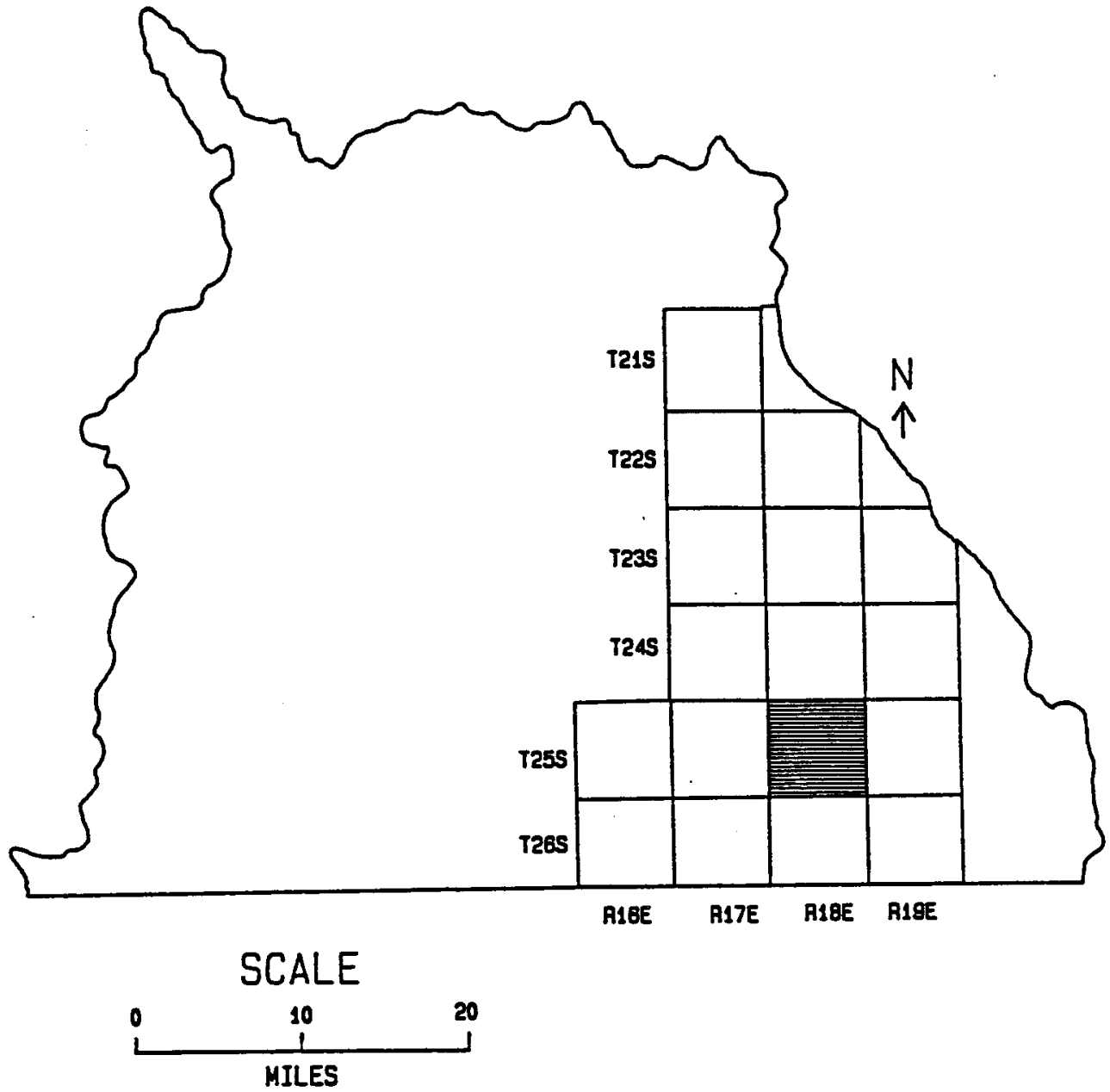

Figure 3-19. Study and potential production areas in the Crow Flats Area, New Mexico 


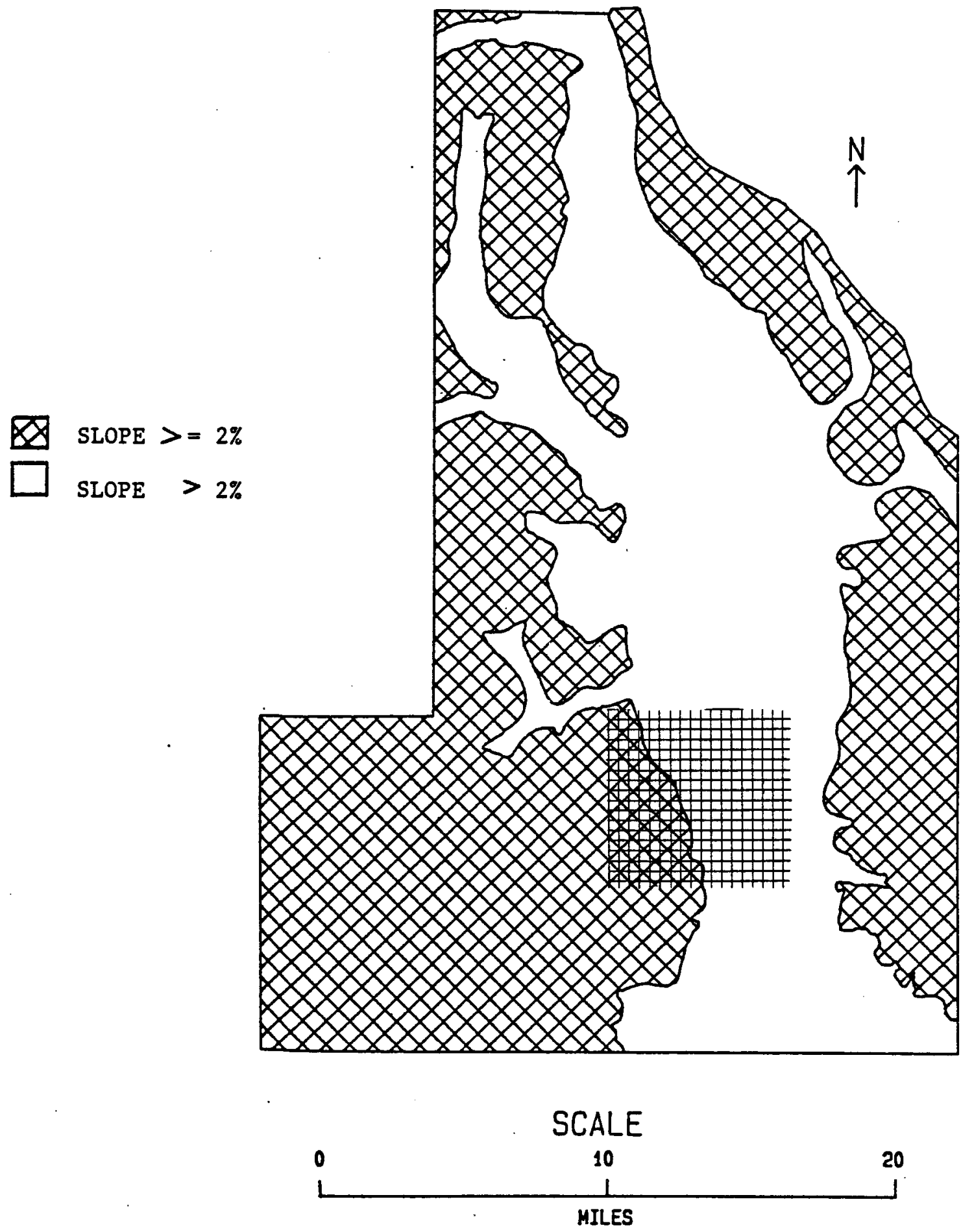

Figure 3-20. Crow Flats Area, places with land slopes that exceed $2 \%$ within the study area and potential production areas 


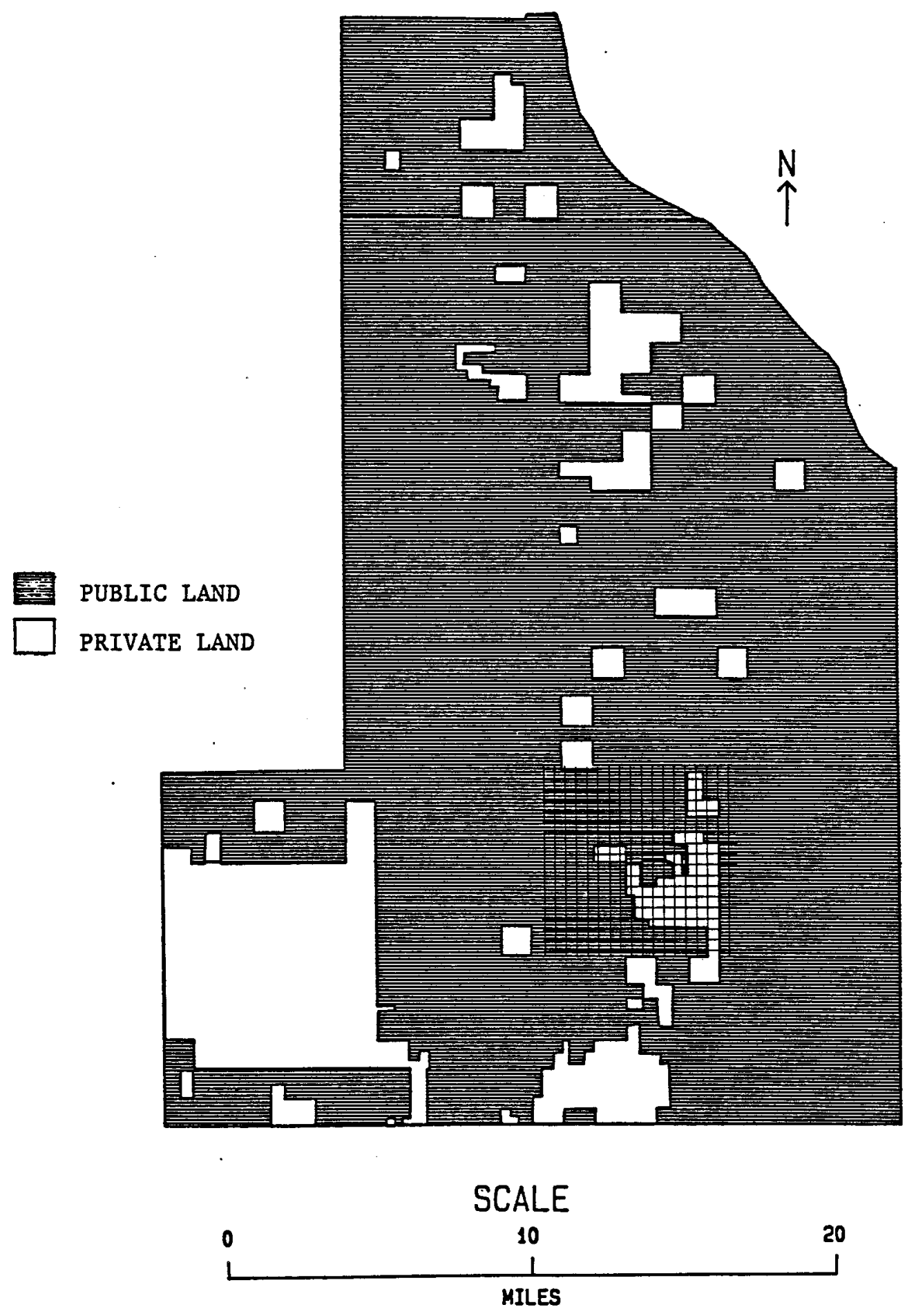

Figure 3-21. Crow Flats Area, land ownership within study area and potential production areas 
are also limited on the north and east by outcrops of limestone rock. To the south of the area of interest, acceptable locations were limited by the New Mexico-Texas state line. The researchers did not have access to data for Texas, although the valley of the basin runs south into the state of Texas and it is reasonable to believe that acceptable sites can be located in Texas. To the east of the study area lies the Corundas Mountains, which produce land slopes that are greater than $2 \%$. The eastern edge is also limited geologically by outcrops of limestone rocks. Within the study area, land ownership patterns were digitized and areas with highest potential for microalgae production facilities were located.

\subsubsection{Groundwater Resources}

The Bjorklund (1957) report contained depth-to-groundwater data. The central portion of the north-south-trending valley contains shallow water (less than $100 \mathrm{ft}$ ). Depth to groundwater increases near the surrounding hills both to the east and west, and depths increase to $400 \mathrm{ft}$ in the area of limestone outcrops.

Recharge is minimal in the basin and groundwater mining is occurring. There were significant declines in groundwater levels in the 1950s, but the rate of change in water levels has stabilized because of reduced pumpage. Some decline has continued to occur, and any new use of groundwater in the basin will result in additional declines in the piezometric surface (Figure 3-22).

\subsubsection{Groundwater Quality}

Figure 3-23 presents the groundwater quality (as specific conductance) in the study area in the Crow Flats area. Again, this map is of limited value for specific site selection because very few wells have been sampled. Water quality at the edges of the valley floor is about 1000 micromhos specific conductance; water quality in the valley floor ranges from 1500 to 3000 micromhos. Assuming that a specific conductance of 1000 micromhos is equivalent to a TDS of $750 \mathrm{mg} / \mathrm{L}$, then the poorest quality water in the basin would have a TDS of less than $2500 \mathrm{mg} / \mathrm{L}$.

\subsubsection{Potential Production Areas}

A limited study area within the Crow Flats area was identified. This area lies in the southeast portion of the Salt Basin bordering on the New Mexico-Texas state line on the south (Figure 3-1). North and east of the study area, slopes greater than $2 \%$ exist near the Guadalupe Mountains. Potential sites were also limited on the north and east by outcrops of limestone rock. To the south, acceptable locations were limited by the New Mexico-Texas state line. The researchers did not have access to data for Texas. To the east of the area of interest lie the Cornudas Mountains, which produce land slopes that are greater than $2 \%$. The eastern edge is also limited geologically by outcrops of limestone rocks.

There is one potential production area in the Crow Flats area where all of the SERI criteria for a facility are met. This area is situated on a north-south axis from the New Mexico-Texas state line in the south (T.26 S.) to Pinon Creek Drainage in the north (T.21 S.) (Figure 3-19). The average width of this area varies from 4 to $6 \mathrm{mi}$ for an area of about $36 \mathrm{mi}^{2}$. The growing season is in excess of 200 days. The approximate landownership pattern is $20 \%$ private, $70 \%$ federal, and $10 \%$ state (Table $3-7$ ). 


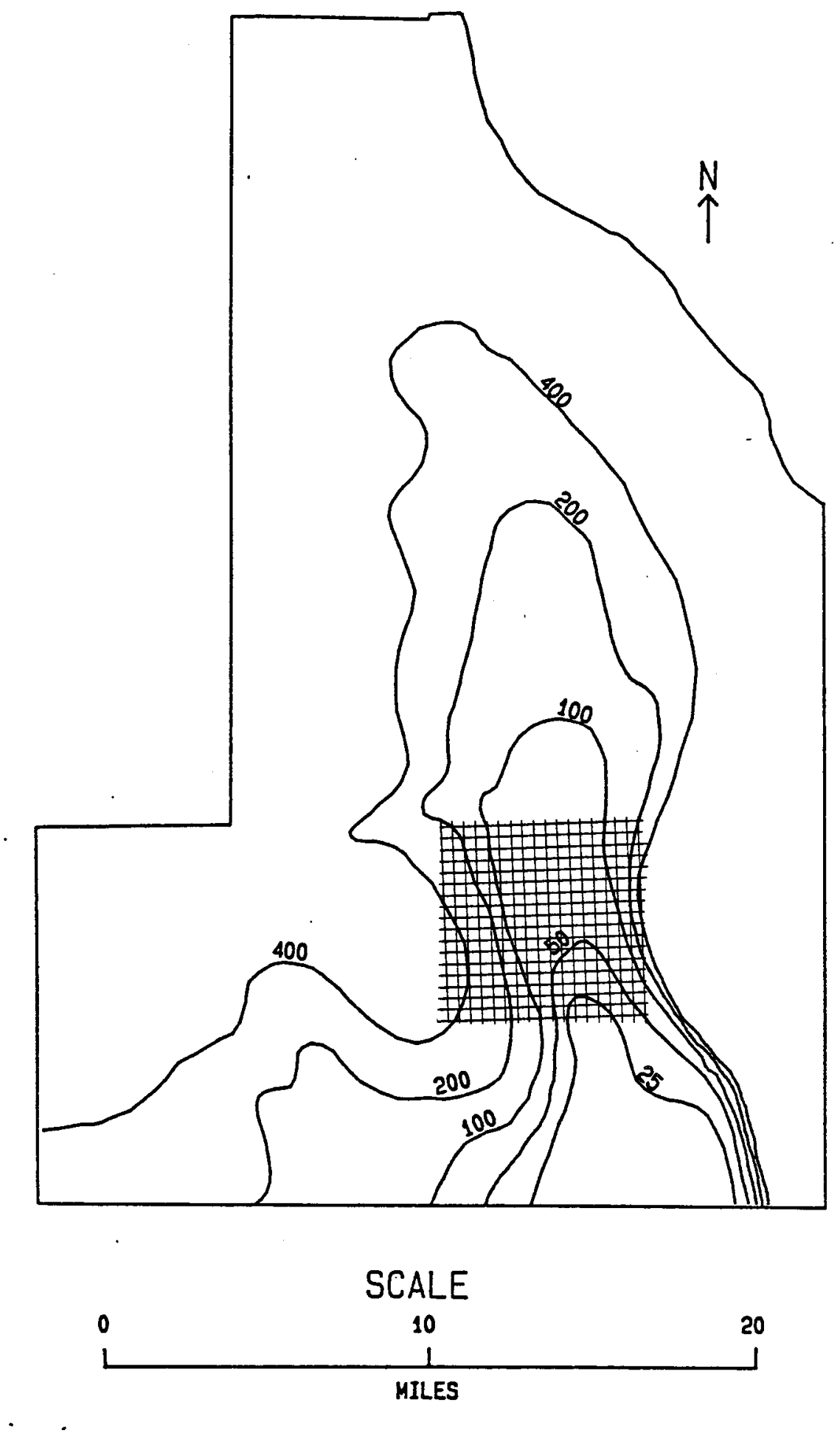

Figure 3-22. Crow Flats Area, depth to groundwater ( $f t$ ) within the study area and potential production areas 


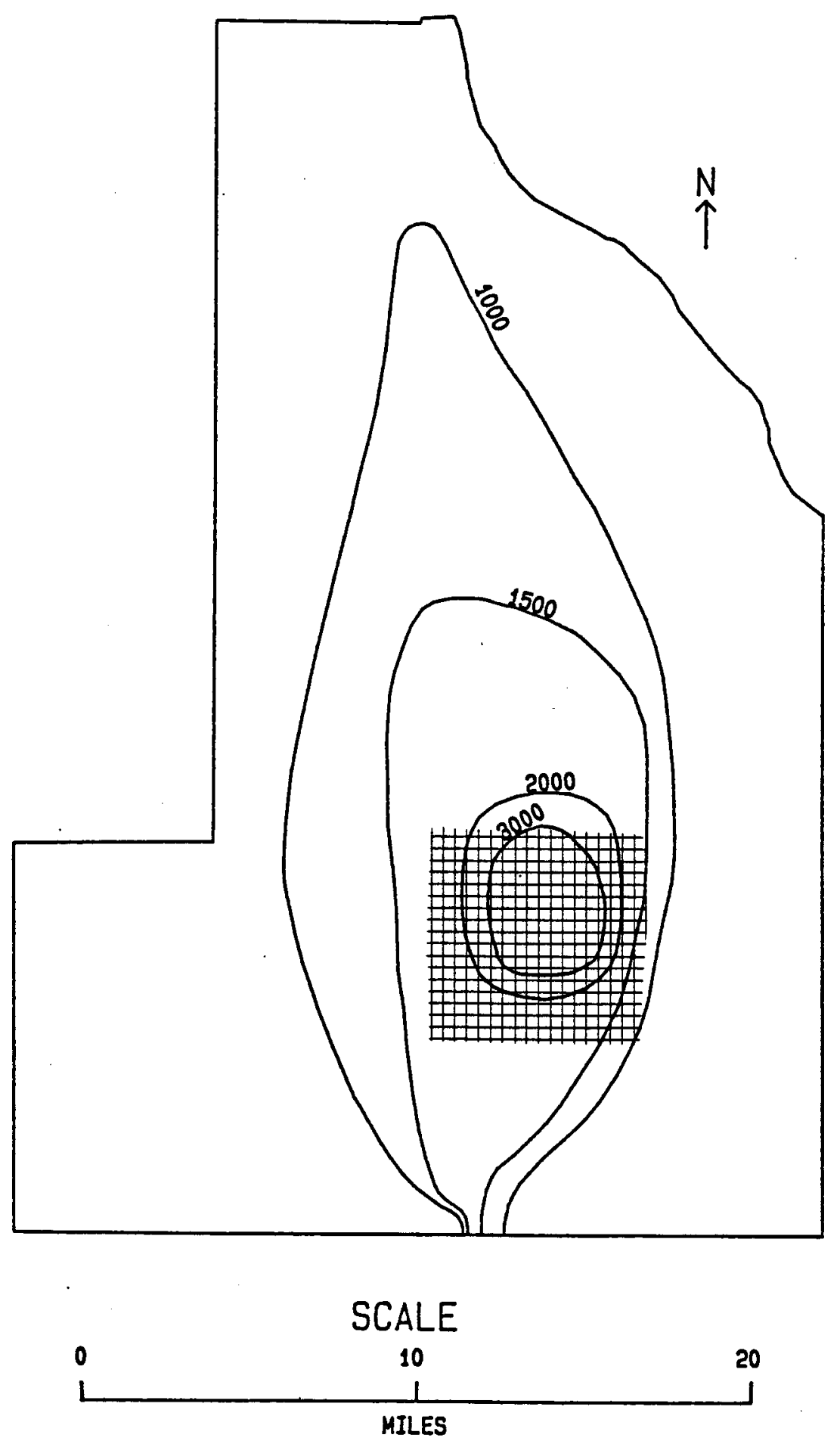

Figure 3-23. Crow Flats Area, water quality (specific conductance in micromhos per $\mathrm{cm}$ at $25^{\circ} \mathrm{C}$ ) within the study area and potential production areas 
Table 3-7. Site and Groundwater Characteristics for Potential Production Areas in the Crow Flats Basin, New Mexico

Potential

Production Area

Site Characteristics

Area

$36 \mathrm{mi}^{2}$

Slope

$<2 \%$

Ownership

Federal

$70 \%$

State

$10 \%$

Private

$20 \%$

Growing Season

200-210 days

Evaporation

70-75 in. $178-191 \mathrm{~cm}$

\section{Water Resources}

Depth to

50-110 ft

Groundwater

15-35 m

Potential

Well-Yield

up to $1000 \mathrm{gpm}$

up to $3790 \mathrm{Lpm}$

Average pH

$$
\text { 6.9-7.3 }
$$

Estimated Reserves

$576,000-1,382,000$ acre $\mathrm{ft}$

Groundwater

Quality

$1000-3000 \mathrm{mg} / \mathrm{L}$

Ionic

Composition

Calcium

Sodium and Potassium

224-556 mg/L

$22-65 \mathrm{mg} / \mathrm{L}$

Magnesium

Sulfate

Chlorine

$177-264 \mathrm{mg} / \mathrm{L}$

Bicarbonate 
Potential well-yields for the area of interest were obtained from a New Mexico State Engineer's Office report by Bjorklund (1957). In the valley fill, reported well-yields ranged from 350 to $840 \mathrm{gpm}$, with several wells reporting more than $1000 \mathrm{gpm}$. Data from farmers in the area indicate well-yields in excess of $1000 \mathrm{gpm}$ are not uncommon. Potential well-yields would require a minimum of four wells to meet the SERI criteria of 4 million gpd. Depth to groundwater in the $36-\mathrm{mi}^{2}$ area ranges from 25 to $100 \mathrm{ft}$ (Table 3-7). Depth to groundwater increases near the surrounding hills and increases to $400 \mathrm{ft}$ in the area of limestone outcrops.

Water quality at the edges of the valley floor is about $1000 \mathrm{mg} / \mathrm{L}$ TDS; water quality in the valley floor ranges from 1500 to $3000 \mathrm{mg} / \mathrm{L}$ (Table 3-7). The water quality for the alkali flats would be classed as slightly saline with TDS ranging from 1500 to $2500 \mathrm{mg} / \mathrm{L}$.

This water resource may not be available for use in microalgae production because of legal protests from existing water-right owners. This groundwater is currently used for irrigation, livestock, and domestic uses.

\subsubsection{Summary}

When all of the SERI criteria were considered, only one area in the Crow Flats Basin was identified as acceptable for potential microalgae production. Approximately $36 \mathrm{mi}^{2}$ exist that possess the necessary surface and groundwater resource characteristics. An exception to this would be relatively good quality groundwater and possible competition with agricultural uses. Specific well data, including ionic composition, were extracted from Bjorklund (1957).

\subsection{The Tucumcari Area}

\subsubsection{Introduction}

The Tucumcari area is a part of the Canadian River Basin that begins in the northcentral section of New Mexico and drains much of the north-east quadrant of the state. In the vicinity of Tucumcari, topography varies from the alluvial stream valley of the Canadian River to the rolling, cut plains of the irrigated lands in the area to high mesas. The maximum relief is approximately $1000 \mathrm{ft}$ from the top of the mesa that marks Tucumcari Mountain to the bed of Pajarito Creek, a local major drainage channel that runs, from west to east, a distance of about $30 \mathrm{mi}$ before entering the Canadian River near Tucumcari. The other major drainage system in the area is Plaza Larga-Revelto Creek that flows south and east of town and enters the Canadian River near Logan.

Saline waters are found in the shallow groundwater system in the vicinity of Tucumcari. Tucumcari is located in the east-central part of the state, just $40 \mathrm{mi}$ west of the TexasNew Mexico line (Figure 3-24) and is on Interstate Highway 40. Poor quality waters exist in the areas near Tucumcari Lake, Pajarito Creek, Plaza Larga-Revelto Creek, and area springs, seeps, boggs, and waterlogged lands. The usable supply of saline water consists of the evaporation losses from Lake Tucumcari and the perennial flow from the local stream system. The total amount of water that may be available is approximately 3000 to 3500 acre-ft/yr. The sections that follow describe the source of this brackish water, potential well-yields, and the recharge of the groundwater system. 


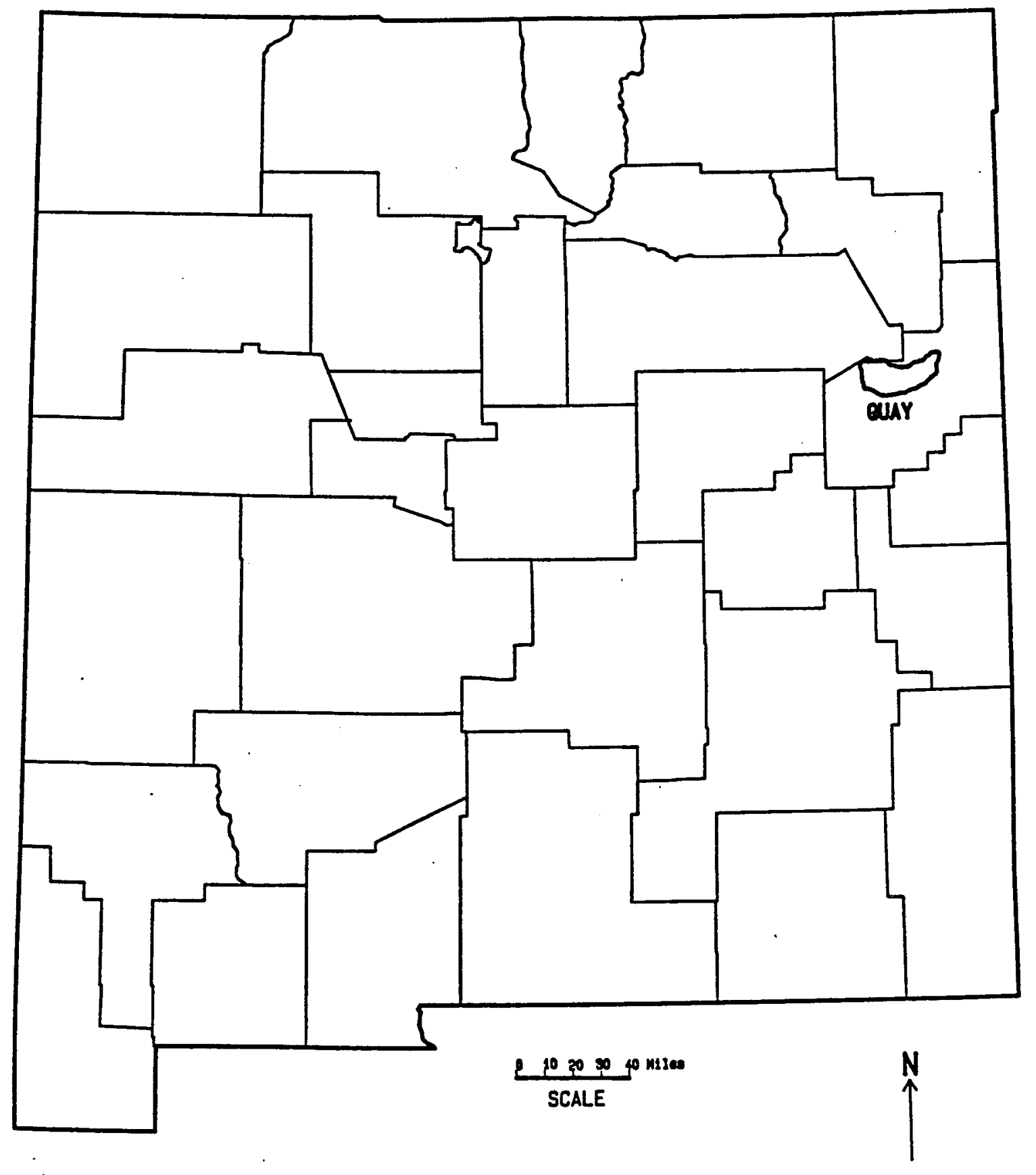

Figure 3-24. Location of the Tucumcari Area, New Mexico 


\subsubsection{Setting and Climatic Characteristics}

Tucumcari is the principal community in the area, with a population of about 7000 . Water supplies for the town come from nearby well fields. Potential sources of saline water in the vicinity are associated with the irrigation system of the Arch-Hurley Conservancy District. The project was built in the 1940s and furnishes water to about 40,000 acres by way of a $30-\mathrm{mi}$ canal from Conchas Reservoir located to the northwest of Tucumcari. Principal crops grown on district lands are wheat, alfalfa, and sorghum.

The Tucumcari area lies at an elevation of about $4000 \mathrm{ft}$ above sea level. The effects of latitude and elevation combine to give the region a semiarid climate with moderate temperatures and a short, but acceptable growing season. Annual temperatures range from $80^{\circ} \mathrm{F}$ in July to $37^{\circ} \mathrm{F}$ in January. The mean annual temperature is about $60^{\circ} \mathrm{F}$ (Table 3-8).

Regional annual rainfall averages 14 to 15 in./yr with most of the precipitation derived from summer storms that, while local in nature, can result in high rates of rain for short periods of time. Winter snows rarely accumulate and snowfall averages only $10 \%$ of the total annual precipitation. The growing season is typically 191 days per year from April 16 (the average date of the last killing frost) to October 25 (the average date of the first killing frost) (Table 3-8).

\subsubsection{Area Geology and Aquifer Recharge}

Because of the topography of the Tucumcari area, it is possible to see many of the geological formations of interest as they outcrop in the relief of the river and creek channels and on the mesas, of which Tucumcari Mountain is the highest. The deepest and oldest formation of interest is the Entrada Sandstone, which is the principal aquifer in the area. The depth of wells taking water from the Entrada are as shallow as 50 to $60 \mathrm{ft}$, but depths of about 350 to $400 \mathrm{ft}$, as those in the municipal well field, are more common in the Tucumcari vicinity.

Water quality in the Entrada Sandstone is quite good: calcium $30 \mathrm{mg} / \mathrm{L}$, chlorides 10 to $15 \mathrm{mg} / \mathrm{L}$, sulfates 35 to $65 \mathrm{mg} / \mathrm{L}$, and TDS 550 to $650 \mathrm{mg} / \mathrm{L}$. Recharge to the Entrada Sandstone comes principally in those areas where it outcrops; a relatively high percentage of the available precipitation on the outcrop zone is recharged. There is some recharge to the Entrada from the Morrison, the next formation upward, where the pressure head in the Entrada is below that in the Morrison.

Above the Morrison are the Tucumcari Shale, the Mesa Rica Sandstone, and the Pajarito Shale. Depending on the locale, alluvial materials of various ages may be found. None of these formations contribute significantly to the recharge of the Entrada because of their low permeability and because they are typically above the water table. Another factor is the lack of any significant water course crossing the alluvia within the city.

\subsubsection{Effect of Irrigation on Area Recharge}

The Arch-Hurley Conservancy District began irrigation deliveries in 1946 and an almost immediate increase in water levels in alluvial wells occurred. The water level in one well rose more than $100 \mathrm{ft}$ from 1952 to 1962 . Tucumcari Lake was originally, a playa, but it soon became a permanent body of water that has grown to about $1 \mathrm{mi}^{2}$ in area since irrigation began. The source of this water appears to be leakage from the unlined canals and laterals as water levels fluctuated with the annual introduction of irrigation water into the transmission system. Recharge to the shallow aquifers from these ditches 
Table 3-8. Selected Climatic Data for Stations within the Tucumcari Basin, New Mexico

\begin{tabular}{|c|c|c|}
\hline & Logan & Tucumcari \\
\hline $\begin{array}{l}\text { Elevation } \\
\text { (above msl) }\end{array}$ & $3830 \mathrm{ft}$ & $4096 \mathrm{ft}$ \\
\hline $\begin{array}{l}\text { Average days } \\
\text { above } 32^{\circ} \mathrm{F}\end{array}$ & 185 days & 182 days \\
\hline $\begin{array}{l}\text { Average frost- } \\
\text { free period }\end{array}$ & $\begin{array}{l}\text { April 19- } \\
\text { October } 21\end{array}$ & $\begin{array}{l}\text { April 16- } \\
\text { October } 25\end{array}$ \\
\hline $\begin{array}{l}\text { Mean annual } \\
\text { precipitation }\end{array}$ & $14.5 \mathrm{in}$. & $15.1 \mathrm{in.}$ \\
\hline $\begin{array}{l}\text { Maximum mean } \\
\text { monthly air } \\
\text { temperature }\end{array}$ & $\begin{array}{l}\text { July } \\
80.1^{\circ} \mathrm{F}\end{array}$ & $\begin{array}{l}\text { July } \\
79.1^{\circ} \mathrm{F}\end{array}$ \\
\hline $\begin{array}{l}\text { Minimum mean } \\
\text { monthly air } \\
\text { temperature }\end{array}$ & $\begin{array}{l}\text { January } \\
37.5^{\circ} \mathrm{F}\end{array}$ & $\begin{array}{l}\text { January } \\
37.7^{\circ} \mathrm{F}\end{array}$ \\
\hline $\begin{array}{l}\text { Average annual } \\
\text { air temperature }\end{array}$ & $58.5^{\circ} \mathrm{F}$ & $58.2^{\circ} \mathrm{F}$ \\
\hline
\end{tabular}

Source: New Mexico State Engineer 1975d

has been estimated to be about 2000 acre-ft/yr (Trauger and Bushman 1964). Soon after the initiation of the irrigation system, springs in the area began to appear, perennial flow in area streams began, and boggy, waterlogged lands developed. There has also been a corresponding decline in water quality in these surface waters and in the shallow groundwater. Water quality in the surface system (creeks and springs) now has the following characteristics: sulfates 500 to $1400 \mathrm{mg} / \mathrm{L}$, chlorides 70 to $270 \mathrm{mg} / \mathrm{L}$, and TDS of 2100 to $4900 \mathrm{mg} / \mathrm{L}$.

\subsubsection{Summary}

The saline waters available in the Tucumcari area are the result of irrigation return flows and leakage from the canal and lateral system. The volume and the potential yields of wells in the shallow alluvium are not sufficient to warrant a microalgae production facility. However, some use of the shallow and surface waters may be of merit because they tend to degrade the quality of the Canadian River.

The Tucumcari area was removed from consideration because the volume of saline water and potential well-yields in the area were too low to meet SERI criteria for consideration as a site for microalgae production. The saline waters in the area are largely a result of irrigation return flows and leakage from the canal and lateral system. 


\subsection{The Pecos Basin}

\subsubsection{Setting and Climatic Characteristics}

The Pecos Basin lies in the Great Plains Physiographic Province (Figure 3-25). Like all of southeastern New Mexico, the geology is characterized by strata of the Permian and Triassic ages, lying at or near the surface (New Mexico Geological Society 1982). Mean air temperature ranges from $38^{\circ} \mathrm{F}$ in January to $79^{\circ} \mathrm{F}$ in July (Table 3-9). Precipitation is highly variable but generally ranges from 9 to 16 in. annually (Geohydrology Associates 1978). Pan evaporation averages about $94 \mathrm{in./yr}$. (Gabin and Lesperance 1977) and lake evaporation is about 70 to 75 in./yr. (Figure A-5, Appendix A).

The portion of the Pecos Basin that was considered in this research is contained in Quay, Curry, Roosevelt, Lea, Eddy, Chaves, and DeBaca counties. The bulk of the area is in Chaves County (Figure 3-25). The basin is bordered on the east by the Ogallala Aquifer.

\subsubsection{Groundwater Resources}

The water table slopes west-southwest and groundwater flow is generally toward the Pecos River, which forms the western edge of the basin. The well-records tables for Chaves County were searched for wells in T.9, 10, and 11 S. and R.25, 26, and 27 E. This encompasses an 18-mi ${ }^{2}$ area just east of Roswell. Unfortunately, records were found for only six wells that lie within this area. Other nearby locations did not yield better results. The sparsity of data precludes preparation of the detailed maps necessary for further evaluation of the area. Low well-yields suggest the area may be unsuitable for microalgae production.

\subsubsection{Groundwater Quality}

The Pecos Basin (the area east of the Pecos River) was removed from consideration as a potential location for a production facility because the area had poorly documented and very limited data on volume and potential well-yield of saline waters (Geohydrology Associates 1978). One exception is the area immediately east of Roswell (between Roswell and the Pecos River). However, this area is in a declared groundwater basin (Roswell Basin). There is a possible site east of Roswell (The Roswell Saline Water Test Facility), which has a well that produces 400 to $600 \mathrm{gpm}$ pumping from a depth of $120 \mathrm{ft}$ (communication with Mr. Charlie Sparnon of Roswell, New Mexico). If appreciable amounts of saline water are available, the Roswell area may be suited for microalgae production.

\subsubsection{Summary}

Further study of the saline water resources of the Roswell area is needed. However, size of facility (1000 ha), groundwater use, slope, and land ownership constraints in the area were additional factors that led to the elimination of the Roswell area as a potential site. Owners of existing water rights in the area would probably oppose any new appropriations of water because the basin is already overappropriated. Any unappropriated water exists in the area east of the Pecos River and exțends to the Ogallala Aquifer. 


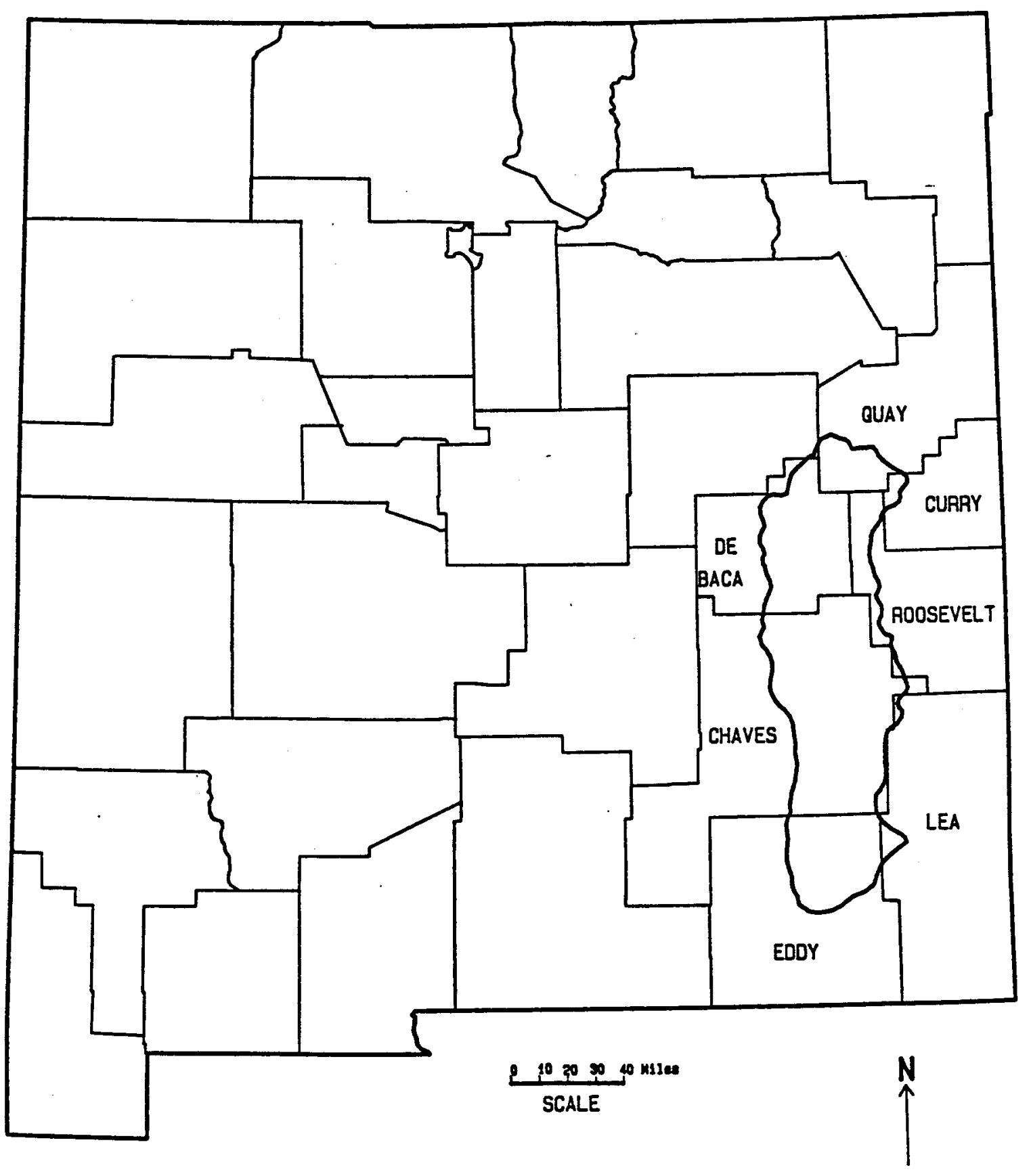

Figure 3-25. Location of the Pecos Basin, New Mexico 
Table 3-9. Selected Climatic Data for Stations in Potential Production Areas in the Pecos Basin, New Mexico

\begin{tabular}{|c|c|c|c|}
\hline & \multicolumn{3}{|c|}{ Potential Production Areas } \\
\hline & Artesia & Roswell & Fort Sumner \\
\hline $\begin{array}{l}\text { Elevation } \\
\text { (above msl) }\end{array}$ & $3375 \mathrm{ft}$ & $3612 \mathrm{ft}$ & $4030 \mathrm{ft}$ \\
\hline $\begin{array}{l}\text { Average days } \\
\text { above } 32^{\circ} \mathrm{F}\end{array}$ & 208 days & 196 days & 191 days \\
\hline $\begin{array}{l}\text { Average frost- } \\
\text { free period }\end{array}$ & $\begin{array}{l}\text { April 19- } \\
\text { October } 21\end{array}$ & $\begin{array}{l}\text { April 16- } \\
\text { October } 25\end{array}$ & $\begin{array}{l}\text { April 15- } \\
\text { October } 22\end{array}$ \\
\hline $\begin{array}{l}\text { Mean annual } \\
\text { precipitation }\end{array}$ & - & $11.6 \mathrm{in}$. & 13.7 in. \\
\hline $\begin{array}{l}\text { Maximum mean } \\
\text { monthly air } \\
\text { temperature }\end{array}$ & -- & $\begin{array}{l}\text { July } \\
79.0^{\circ} \mathrm{F}\end{array}$ & $\begin{array}{l}\text { July } \\
79.3^{\circ} \mathrm{F}\end{array}$ \\
\hline $\begin{array}{l}\text { Minimum mean } \\
\text { monthly air } \\
\text { temperature }\end{array}$ & - & $\begin{array}{l}\text { January } \\
39.6^{\circ} \mathrm{F}\end{array}$ & $\begin{array}{l}\text { January } \\
38.5^{\circ} \mathrm{F}\end{array}$ \\
\hline $\begin{array}{l}\text { Average annual } \\
\text { air temperature }\end{array}$ & - & $59.8^{\circ} \mathrm{F}$ & $58.9^{\circ} \mathrm{F}$ \\
\hline
\end{tabular}

\subsection{The San Juan Basin}

\subsubsection{Setting and Climatic Characteristics}

The San Juan Basin includes the Navajo and Acoma-Zuni sections of the Colorado Plateau Physiographic Province (Figure 3-26). Over most of the region, rocks crop out around the basin margin (New Mexico Geological Society 1982). Average annual precipitation ranges from less than 6 in. near Shiprock to 30 in. at Mt. Taylor; pan evaporation ranges from 63 in. at El Vado Dam to 72 in. at Gallup (Stone et al. 1983). Mean air temperatures range from $26^{\circ}$ to $29^{\circ} \mathrm{F}$ in January and range from $68^{\circ}$ to $75^{\circ} \mathrm{F}$ in July (Table 3-10).

\subsubsection{Groundwater Resources}

The San Juan Basin is of potential interest for microalgae production because moderately saline water lies at less than $500 \mathrm{ft}$ in most places and less than $200 \mathrm{ft}$ in some areas. Potential well-yields are commonly 25 to $100 \mathrm{gpm}$, but locally 100 to $500 \mathrm{gpm}$ capacities are reported (Bureau of Reclamation 1976). 


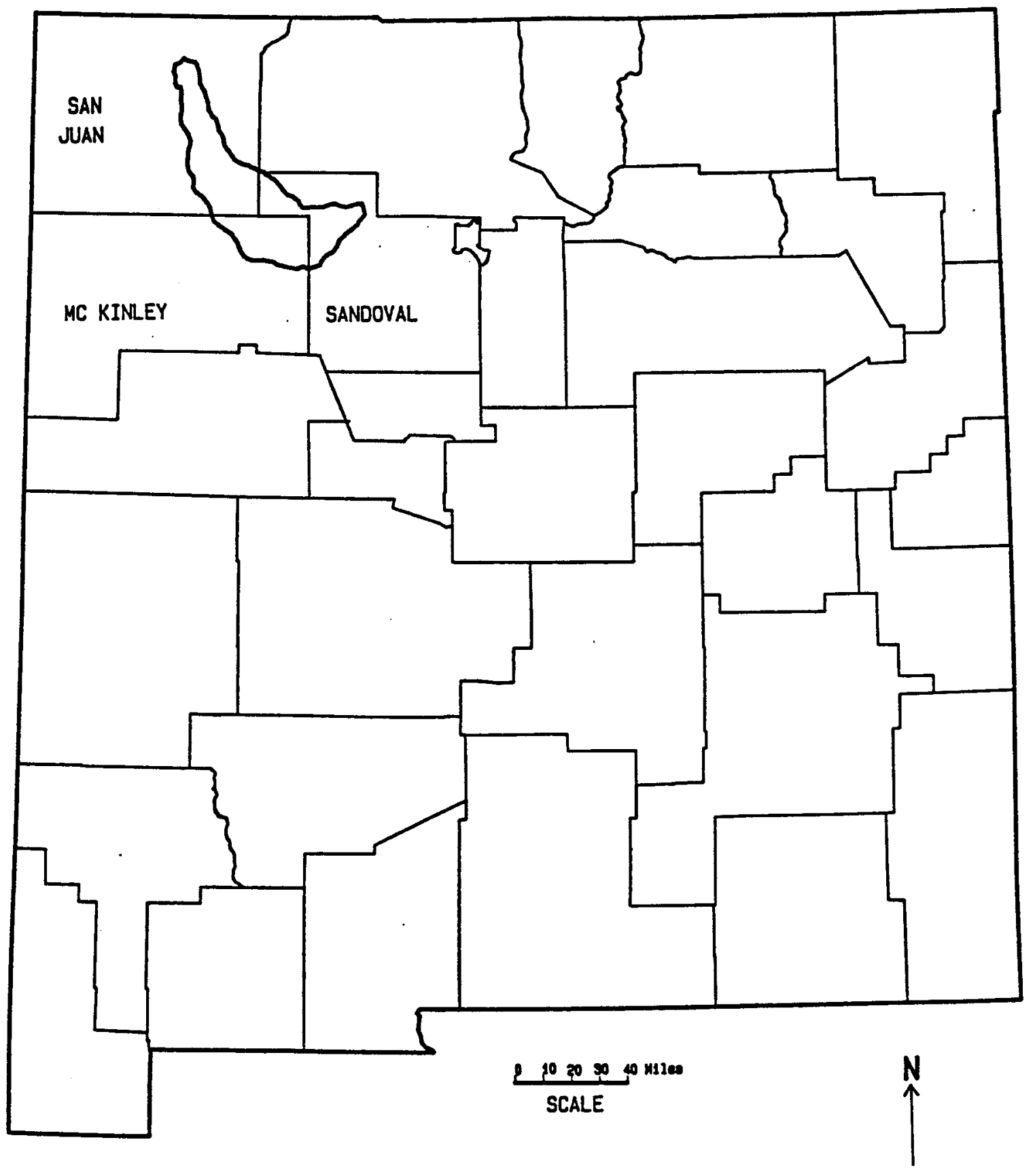

Figure 3-26. Location of the San Juan Basin, New Mexico 
Table 3-10. Selected Climatic Data for Stations in Potential Production Areas in the San Juan Basin, New Mexico

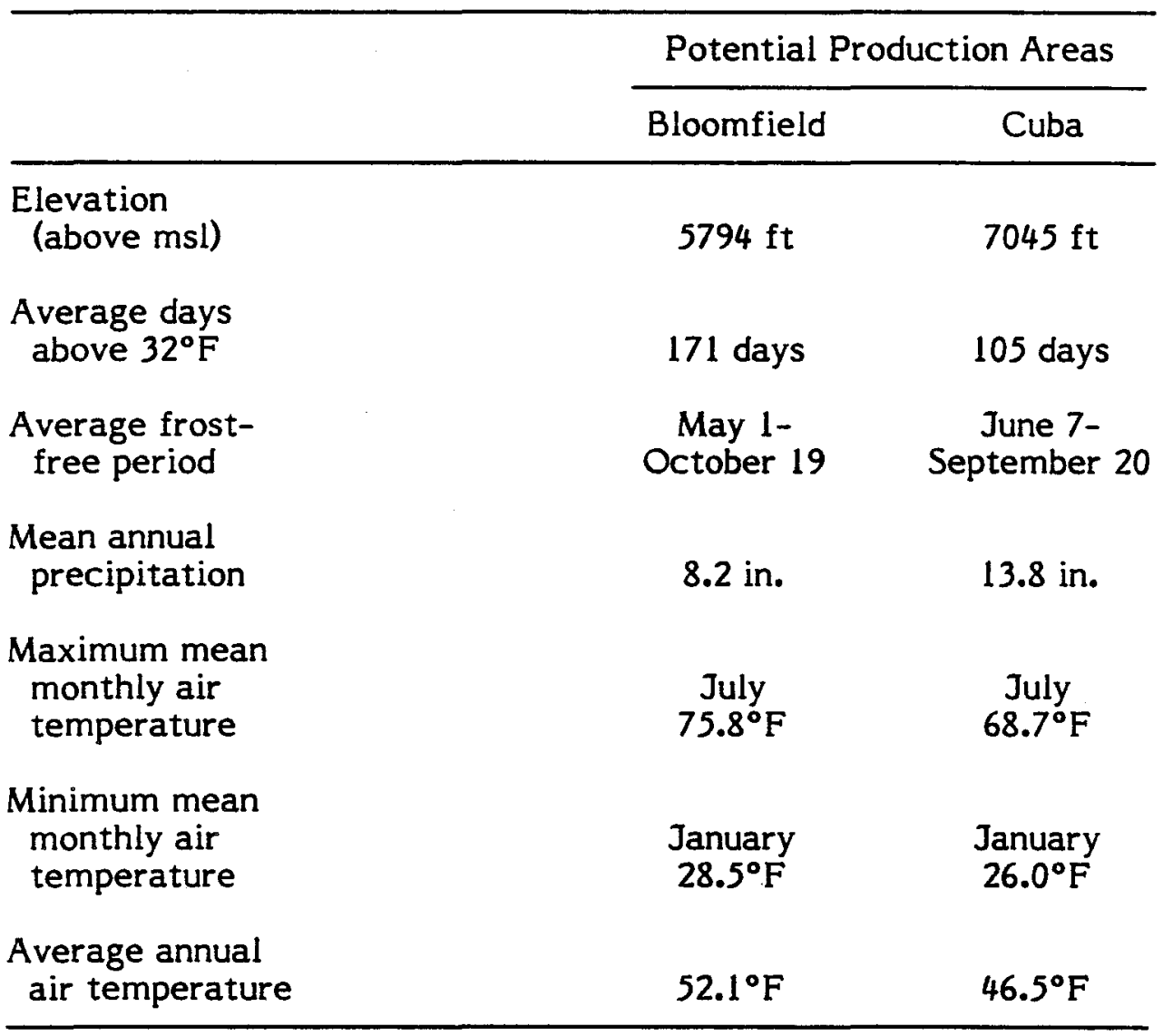

Sources: New Mexico State Engineer 1975e; New Mexico State Engineer $1975 \mathrm{f}$

Most water occurs in artesian sandstone aquifers. The water table and potentiometric surface for these aquifers slope toward discharge areas along the major streams and canyons. Depth of the various aquifers increases toward the center of the basin because of the regional structure. Transmissivity, (T) (hydraulic conductivity times thickness) may be taken as a measure of well-yield. For Cretaceous sandstone aquifers, $T$ ranges from less than 10 to $400 \mathrm{gpd} / \mathrm{ft}$ (per foot of width of aquifer); for Tertiary sandstones, $\mathrm{T}$ is 40 to $200 \mathrm{gpd} / \mathrm{ft}$ (Stone et al. 1983). In most areas, the lower end of the range applies. For wells with a reasonable diameter, yields of less than $300 \mathrm{gpm}$ would probably be obtained and therefore, be considerably less than that required for development of a satisfactory algae production facility.

\subsubsection{Summary}

The San Juan. Basin was also removed from consideration as a potential site for a production facility. The basin contains saline waters, but depths to water and low potential well-yields make the area unsuitable (Stone et al. 1983). The San Juan Basin also has the disadvantage of highly complex land ownership patterns involving tribal Indian, federal, state, and private lands. 


\subsection{SUMMARY AND CONCLUSIONS}

Approximately $25 \%$ of the estimated 20 billion acre-ft of groundwater reserves in New Mexico are classified as fresh or slightly saline. The remaining 15 billion acre-ft of unused water is characterized as moderately saline, very saline, or brine. The location of the state's saline groundwater reserves are relatively well known, but the magnitude of these resources and aquifer characteristics have not been rigorously assessed.

\subsection{Objectives and Methodology}

The major objective of this report was to identify potential site locations for large-scale (1000 ha or 2470 acres) microalgae production facilities in New Mexico using unappropriated saline groundwater resources.

After a review of the 15 billion acre-ft of saline water resources in the state, areas that appeared to meet SERI's criteria for site selection were narrowed to the following--the Tularosa Basin in south-central New Mexico, the Estancia Basin in central New Mexico, the San Juan Basin in northwestern New Mexico, the Tucumcari area on the east side of New Mexico, the area east of the Pecos River in eastern New Mexico, and the Crow Flats area in southern New Mexico (Figure 4-1).

\subsection{Basins Reviewed}

A preliminary analysis was completed for the six locations. The Pecos River Basin, the Tucumcari area, and the San Juan Basin were eliminated for failing to meet the preliminary SERI criteria (Table 4-1).

A detailed analysis using all of the SERI criteria for siting a microalgae production facility was then completed for the remaining three areas--Tularosa Basin, Crow Flats area, and Estancia Basin. These areas possess the necessary land, site characteristics, and groundwater conditions set forth by SERI (Table 4-1).

\subsubsection{Tularosa Basin}

Two potential sites were identified for the Tularosa Basin. Both sites (A \& B) met all of the SERI criteria. One exception may be the relatively low well-yields that are characteristic of the areas in the Tularosa Basin. For a 1000-ha (2470 acres) facility, low well-yields may be offset by more wells.

\subsubsection{Estancia Basin}

Two potential sites were identified for the Estancia Basin. A short growing season of approximately 140 to 160 days would be a major limitation in the basin and would eliminate the basin from consideration for microalgae facilities. One $80-\mathrm{mi}^{2}$ site $(\mathrm{A})$ met all other SERI criteria. The best site for the location of a facility would be near the existing playa lakes. The second site (B) met all of the criteria, with the exception of groundwater quality. The groundwater is classified as slightly saline. An additional limitation for site $B$ is that poorer quality water overlies better quality water with a potential for degradation of the higher quality water. Owners of existing water rights in the area may oppose any new appropriations of water. 


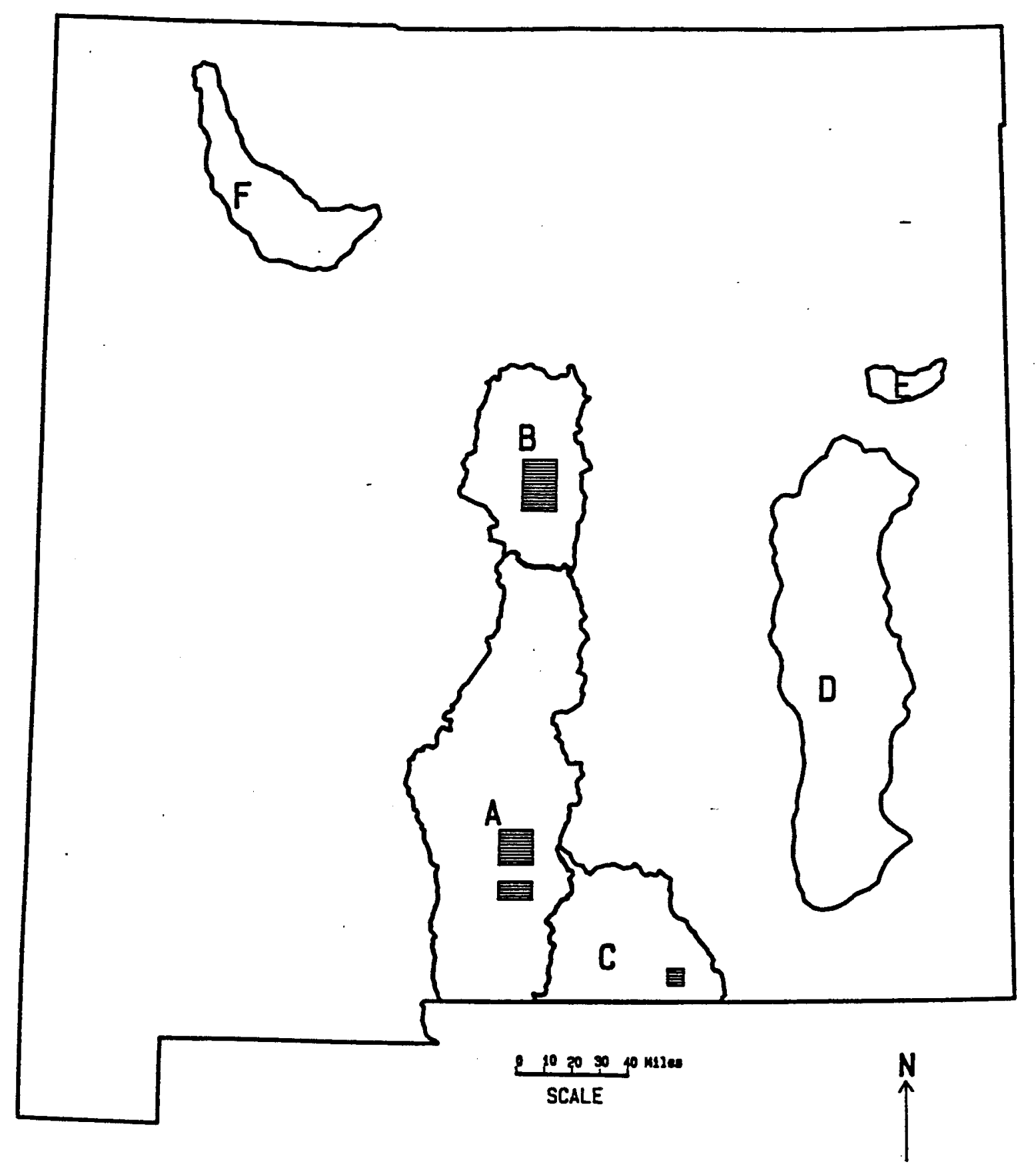

$$
\begin{aligned}
& \text { A - Tularosa Basin } \\
& \text { B - Estancia Basín } \\
& \text { C - Crow Flats Basin }
\end{aligned}
$$

$$
\begin{aligned}
& \text { D - Pecos Basin } \\
& \text { E - Tucuacar } 1 \text { Basin } \\
& \text { F - San wan Basin }
\end{aligned}
$$

Figure 4-1. Potential microalgae production areas in the state of New Mexico 
Table 4-1. Qualitative Summary of Chosen Sites and Specific Criteria Used in Selection of Areas Suitable for Microalgae Production

\begin{tabular}{|c|c|c|c|c|c|c|c|c|}
\hline \multirow[b]{2}{*}{ Criterion } & \multicolumn{2}{|c|}{ Tularosa Basin } & \multirow{2}{*}{$\begin{array}{l}\text { Crow Flats } \\
\text { Basin }\end{array}$} & \multicolumn{2}{|c|}{ Estancia Basin } & \multirow{2}{*}{$\begin{array}{l}\text { Pecos } \\
\text { Basin }\end{array}$} & \multirow{2}{*}{$\begin{array}{l}\text { San Juan } \\
\text { Basin }\end{array}$} & \multirow{2}{*}{$\begin{array}{l}\text { Tucumcari } \\
\text { Basin }\end{array}$} \\
\hline & Site A & Site B & & Site A & Site B & & & \\
\hline $\begin{array}{l}\text { Supply of } \\
\text { Unappro- } \\
\text { priated } \\
\text { Groundwater }\end{array}$ & Available & Available & Available $^{\mathrm{a}}$ & Available & Available & $\begin{array}{l}\text { Limited } \\
\text { Availability }\end{array}$ & Available & Available \\
\hline $\begin{array}{l}\text { Depth to } \\
\text { Saline } \\
\text { Groundwater }\end{array}$ & Satisfactory & Satisfactory & $\begin{array}{l}\text { Marginal to } \\
\text { Satisfactory }\end{array}$ & Satisfactory & Satisfactory & $N / A^{C}$ & $\begin{array}{l}\text { Marginal to } \\
\text { Satisfactory }\end{array}$ & $\begin{array}{l}\text { Marginal to } \\
\text { Satisfactory }\end{array}$ \\
\hline $\begin{array}{l}\text { Potential } \\
\text { Well-Yield }\end{array}$ & $\begin{array}{l}\text { Marginal to } \\
\text { Satisfactory }\end{array}$ & $\begin{array}{l}\text { Marginal to } \\
\text { Satisfactory }\end{array}$ & Satisfactory & Satisfactory & Satisfactory & Unsatisfactory & Unsatisfactory & $N / A$ \\
\hline $\begin{array}{l}\text { Water Qual- } \\
\text { ity (TDS) }\end{array}$ & Satisfactory & Satisfactory & Marginal & Satisfactory & Marginal & Satisfactory & Satisfactory & Marginal \\
\hline $\begin{array}{l}\text { Adequate } \\
\text { Reserves }\end{array}$ & Yes & Yes & Yes & Yes & Yes & Uncertain & Yes & No \\
\hline $\begin{array}{l}\text { Growing } \\
\text { Season }\end{array}$ & Satisfactory & Satisfactory & Satisfactory & Unsatisfactory & Unsatisfactory & Satisfactory & Unsatisfactory & $\begin{array}{l}\text { Marginal to } \\
\text { Satisfactory }\end{array}$ \\
\hline Land Slope & Satisfactory & Satisfactory & Satisfactory & Satisfactory & Satisfactory & $\mathbf{N} / \mathbf{A}$ & $\mathrm{N} / \mathrm{A}$ & $\mathbf{N} / \mathbf{A}$ \\
\hline Ownership & $\begin{array}{l}\text { Majority is } \\
\text { Private }\end{array}$ & $\begin{array}{l}\text { Majority is } \\
\text { Private }\end{array}$ & $\begin{array}{l}\text { Majority is } \\
\text { Federal }\end{array}$ & $\begin{array}{l}\text { Majority is } \\
\text { Private }\end{array}$ & $\begin{array}{l}\text { Majority is } \\
\text { Private }\end{array}$ & $N / A^{d}$ & $\mathbf{N} / \mathbf{A}$ & $N / A$ \\
\hline $\begin{array}{l}\text { Data Base } \\
\text { Quality }\end{array}$ & Excellent & Excellent & $\begin{array}{l}\text { Poor to } \\
\text { Good }\end{array}$ & Good & Good & Poor & Good & Good \\
\hline $\begin{array}{l}\text { Further } \\
\text { Study } \\
\text { Recommended }\end{array}$ & Yes & Yes & Yes & No & No & Yes $^{e}$ & No & No \\
\hline
\end{tabular}

$\mathrm{N} / \mathrm{A}=$ not available.

a Unappropriated water is available, but competition from agriculture is likely because water quality is suitable for agriculture.

bunappropriated water is available, but competition from existing uses may exclude microalgae production.

$C_{D}$ ata on depth to groundwater was available only for the Pecos Valley not the Pecos Basin.

Ownership was not described for the Pecos Basin. Ownership in the Pecos Valley was predominantly private.

Further study is recommended for the area around Roswell if less than a 1000 ha facility is considered. 


\subsubsection{Crow Flats Area}

One $36-\mathrm{mi}^{2}$ area in the Crow Flats area was identified as a potential site. The area is on the valley floor in the alkali flat portion of Crow Flats. However, the water would be classified as slightly saline and is currently being used for irrigation, livestock, and domestic purposes. It is unlikely that current water-right holders will readily accept requests for new appropriations of groundwater.

\subsection{Conclusions}

The Tularosa Basin was judged as the best-suited area for a 1000-ha microalgae production facility, and Crow Flats was the next best alternative. The Estancia Basin has the limitation of a short growing season and possible opposition from current water-right holders.

\subsubsection{Additional Study Areas}

There are two potential sites where additional research on the saline water resources would be required to determine if enough saline water is available at economic depths. They are the area east of Roswell in Chaves County and the Jornada del Muerto in Sierra and Socorro counties. 


\subsection{REFERENCES}

Berkstresser, C.S., and W.A. Mourant, 1966, Ground-Water Resources and Geology of Quay County, New Mexico, Ground-water Report 9, New Mexico Bureau of Mines and Mineral Resources.

Bjorklund, L.J., 1957, Reconnaissance of Groundwater Conditions in the Crow Flats Area, Otero County, New Mexico, Technical Report 8, New Mexico State Engineer.

Boegl, W.J., M.M. Dahl, and H.E. Remmers, May 1983, Southwest Region Solar Pond Study for Three Sites--Tularosa Basin, Malaga Bend, and Canadian River, Press Project No. DE-30, U.S. Department of Interior.

Burau, R.G. "Environmental Chemistry of Selenium," July 1985, California Agriculture, Vol. 39, Nos. 7 and 8, pp. $16-18$.

Bureau of Reclamation, April 1984, Tularosa Basin Water and Energy Study, New Mexico, Amarillo, TX: U.S. Department of Interior.

Bureau of Reclamation in Cooperation with the State of New Mexico, November 1976, New Mexico Water Resources: Assessment for Planning Purposes, Amarillo, TX: U.S. Department of the Interior.

Diemer, J.A. and J.F. Morrison, 1984, New Mexico Land Use, By County 1977-1982, Research Report 532.

DuMars, C.T., 1984, The Impact of Recent Court Decisions Concerning Water and Interstate Commerce on Water Resources of the State of New Mexico, $A$ report to Governor Toney Anaya and the Legislative Council pursuant to Laws, 1983, Chapter 98. Report prepared by the Water Law Study Committee, University of New Mexico Law School.

DuMars, C.T., F.L. Brown, R.G. Cummings, R. Lansford, A.B. Rodgers, and A.E. Utton, January 1986. State Appropriation of Unappropriated Groundwater: A Strategy for Insuring New Mexico a Water Future, New Mexico Water Resources Research Institute and University of New Mexico Law School Special Report.

Gabin, V.L. and L.E. Lesperance, 1977, New Mexico Climatological Data, Precipitation, Temperature, Evaporation, and Wind--Monthly and Annual Means, Socorro, NM: W. K. Summers and Associates.

Gelhar, L.W., March 1977, Use of Brackish Groundwater Resources for Regional Energy Center Development, Tularosa Basin, New Mexico, Preliminary Evaluation, Contract No. FEA/G-77/101, Los Alamos, NM: Los Alamos Laboratories.

Geohydrology Associates, 1978, Collection of Hydrologic Data, Eastside Roswell Range EIS Area, New Mexico, Open-file Report 95, New Mexico Bureau of Mines and Mineral Resources.

Hernandez, J.W., 1986, Criteria for the Identification of Potential Sites for Irrigation with Saline Waters in New Mexico, Unpublished Engineering Research Report, New Mexico State University. 
Kelly, T.E., B.N. Myers and L.A. Hershey, May 1970, Saline Ground-Water Resources of the Rio Grande Drainage Basin - A Pilot Study, Research and Development Progress Report No. 560, U.S. Department of Interior, Office of Saline Water.

Krothe, N.C. and J.B. Weeks, 1982, Dissolved Solids and Sodium in Water from the High Plains Aquifer in Parts of Colorado, Kansas, Nebraska, New Mexico, Oklahoma, South Dakota, Texas and Wyoming, Hydrologic Atlas No. 658, U.S. Geological Survey.

Lansford, R.R., et al., February 1976, A Preliminary Economic Feasibility Study for the Establishment of an Energy-water Complex in the Tularosa Basin. Report No. 068, New Mexico Water Resources Research Institute.

Lansford, R.R., et al., June 1982, High Plains-Ogallala Aquifer Study: New Mexico, WRRI Report No. 151, New Mexico Water Resources Research Institute.

Lansford, R.R., et al., 1985, Sources of Irrigation Water and Irrigated and Dry Cropland Acreages in New Mexico, by County, 1980-84, Research Report 571, Agricultural Experiment Station, New Mexico State University.

MacMillan, J.R., R.C. Naff, and L.W. Gelhar, December 1976, "Prediction and Numerical Simulation of Subsidence Associated with Proposed Groundwater Withdrawal in the Tularosa Basin, New Mexico," Publication No. 121, Proceedings of the Anaheim Symposium, International Association of Hydrological Sciences, pp. 600-608.

Maxwell, E.L., A.G. Folger, and J.E. Hogg, November 1984, Resource Evaluation and Site Selection for Microalgae Production Systems, SERI/TR-215-2484, Golden, CO: Solar Energy Research Institute.

McLean, J.S., July 1970, Saline Groundwater Resources of the Tularosa Basin, New Mexico, Research and Development Progress Report No. 581, U.S. Department of Interior, Office of Saline Water.

New Mexico Geological Society, 1982, Highway-Geological Map, New Mexico Geological Society, Scale 1:1,000,000.

New Mexico Solar Energy Institute, February 1978, Bio-Production of Liquid Fuels via Algal Captured Solar Energy, Proposal No. NMSU-78-00339, Las Cruces, NM: New Mexico State University.

New Mexico State Engineer and New Mexico Interstate Stream Commission, 1975a, County Profile: Chaves County Water Resources Assessment for Planning Purposes, Santa Fe, NM.

New Mexico State Engineer and New Mexico Interstate Stream Commission, 1975b, County Profile: De Baca County Water Resources Assessment for Planning Purposes. Santa Fe, NM.

New Mexico State Engineer and New Mexico Interstate Stream Commission; 1975c, County Profile: Lea County Water Resources Assessment for Planning Purposes, Santa Fe, NM. 
New Mexico State Engineer and New Mexico Interstate Stream Commission, 1975d, County Profile: Quay County Water Resources Assessment for Planning Purposes, Santa Fe, NM.

New Mexico State Engineer and New Mexico Interstate Stream Commission, 1975e, County Profile: Sandoval County Water Resources Assessment for Planning Purposes, Santa Fe, NM.

New Mexico State Engineer and New Mexico Interstate Stream Commission, 1975f, County Profile: San Juan County Water Resources Assessment for Planning Purposes, Santa Fe, NM.

New Mexico State Engineer and New Mexico Interstate Stream Commission, 1975g, County Profile: Torrance County Water Resources Assessment for Planning Purposes. Santa Fe, NM.

Smith, R.E., 1957, Geology and Ground-Water Resources of Torrance County, New Mexico, Ground-Water Report 5, New Mexico Bureau of Mines and Mineral Resources.

Stone, W.J, F.P. Lyford, P.F. Frenzel, N.H. Mizell, and E.T. Padgett, 1983, Hydrogeology and Water Resources of the San Juan Basin, New Mexico, Hydrologic Report 6, New Mexico Bureau of Mines and Mineral Resources.

Trauger, F.D. and F.X. Bushman, 1964, Geology and Groundwater in the Vicinity of Tucumcari, Quay County, New Mexico, Technical Report 30, New Mexico State Engineer.

U.S. Department of Commerce, July 1986, Climatological Data, Texas. Vol. 91, No. 7. 
APPENDIX A

NEW MEXICO

CLIMATE CHARACTERISTIC MAPS 


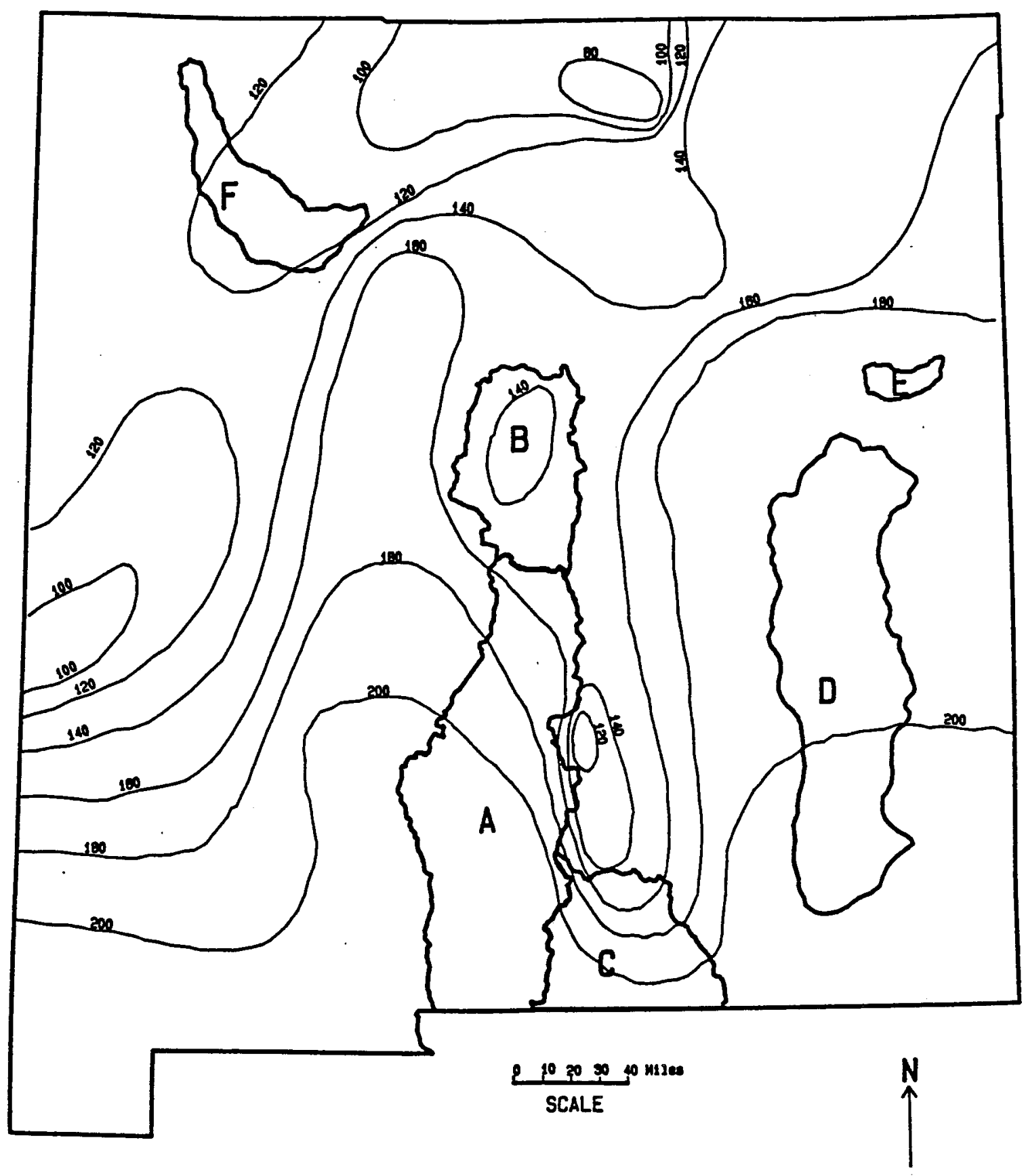

$$
\begin{aligned}
& \text { A = Tularosa Basín } \\
& \text { B - Estancia Basin } \\
& \text { C - Crow Flats Basín }
\end{aligned}
$$

Figure A-1. Median length of growing season (in days, $32^{\circ} \mathrm{F}$ base temperature) showing study areas in New Mexico 


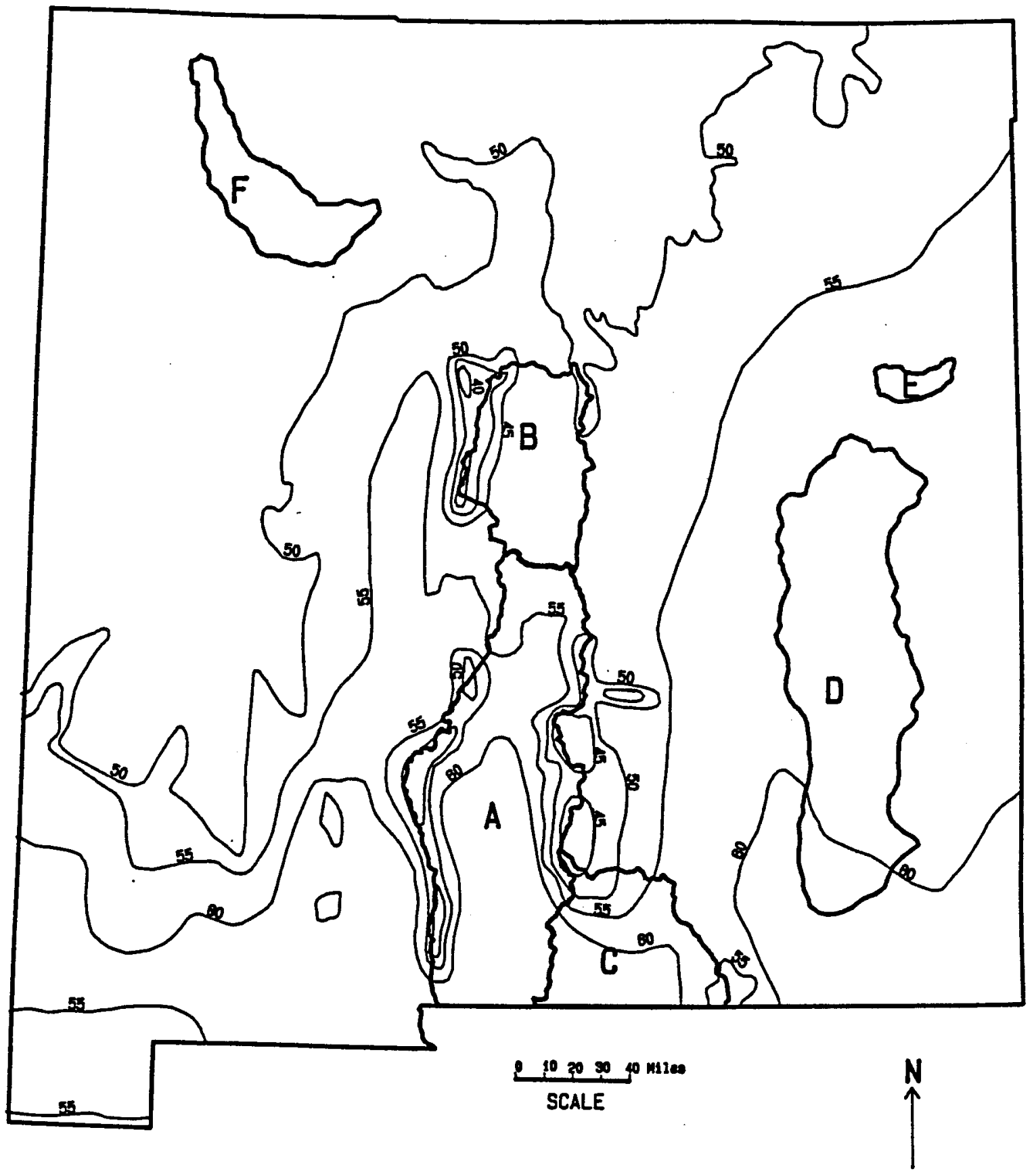

$$
\begin{aligned}
& \text { A - Tularosa Basin } \\
& \text { B- Estancia Basin } \\
& \text { C - Crow Flata Basin }
\end{aligned}
$$

$$
\begin{aligned}
& \text { D - Pecos Basin } \\
& \text { E - Tucuacar } 1 \text { Basin } \\
& F \text { - San Juan Basin }
\end{aligned}
$$

Figure A-2. Annual mean daily temperature (in ${ }^{\circ} \mathrm{F}$ ) showing study areas in New Mexico 

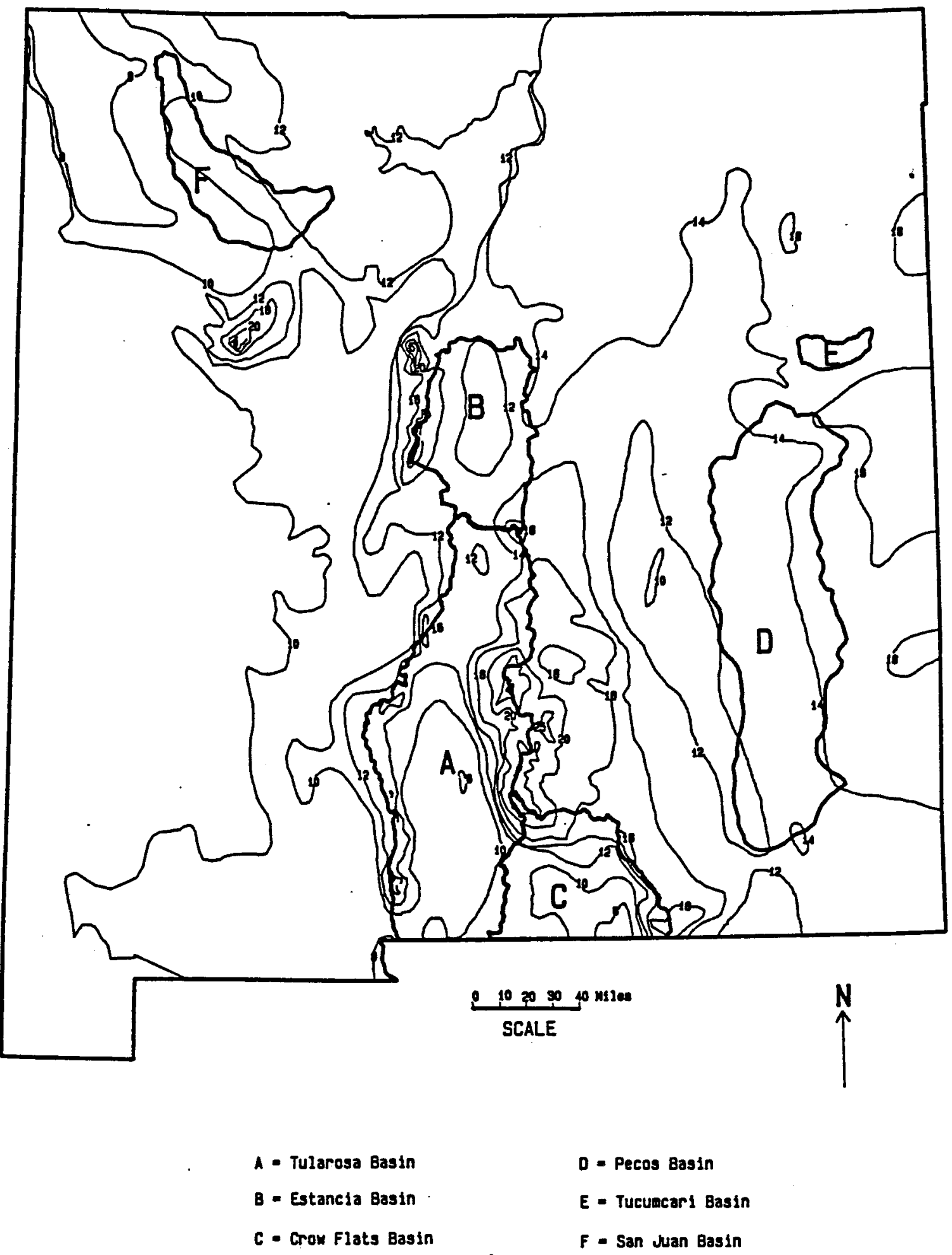

Figure A-3. Normal annual precipitation (in in.) showing study areas in New Mexico 


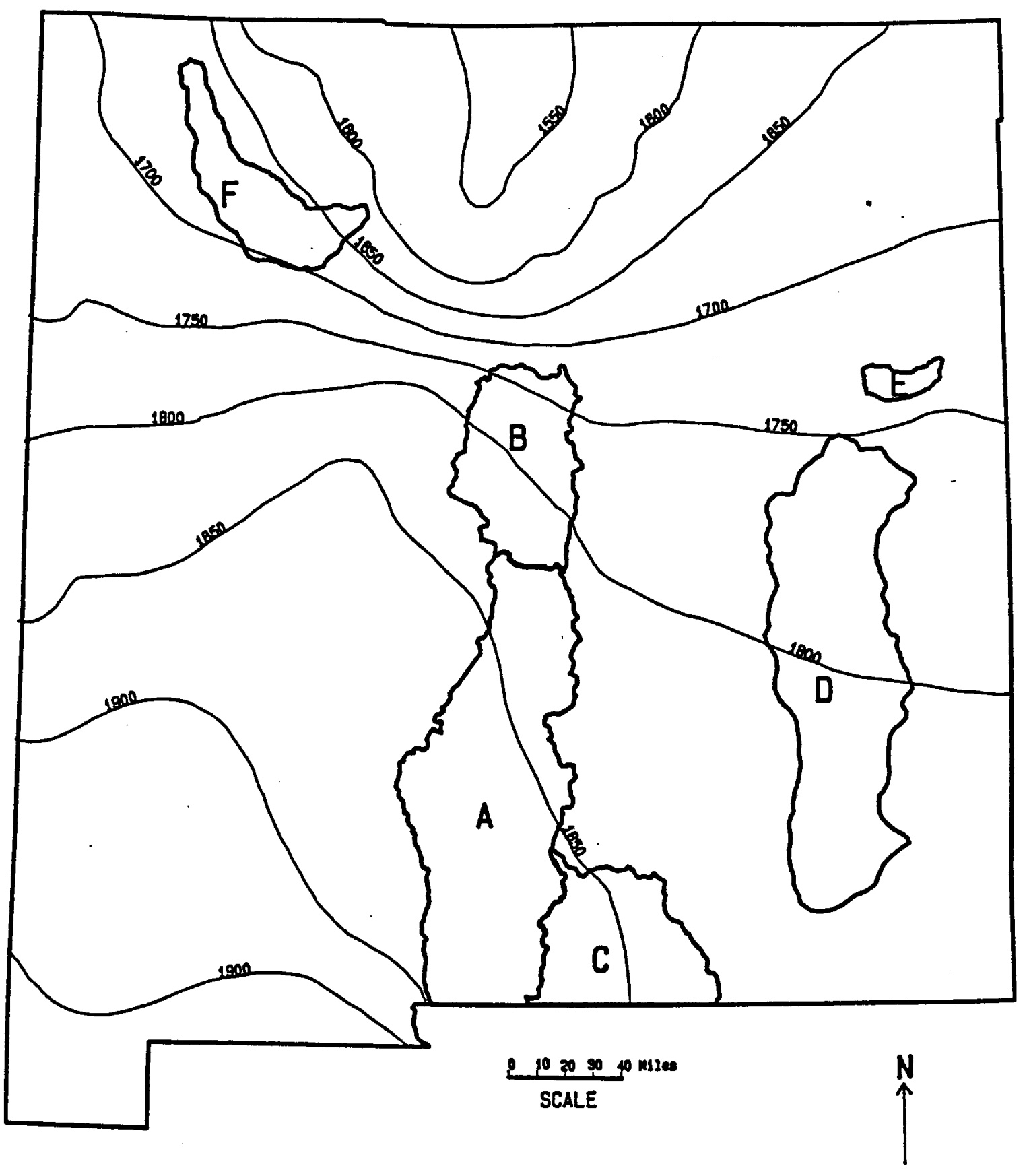
A - Tularosa Basin
D - Pecos Basin
B - Estancia Basin
$E$ - Tucumcar1 Basin
C - Crow Flats Basin
$F=$ San Jan Basin

Figure A-4. Annual mean daily solar radiation (in $\mathrm{Btu} / \mathrm{ft}^{2} / \mathrm{d}$ ) showing study areas in New Mexico 


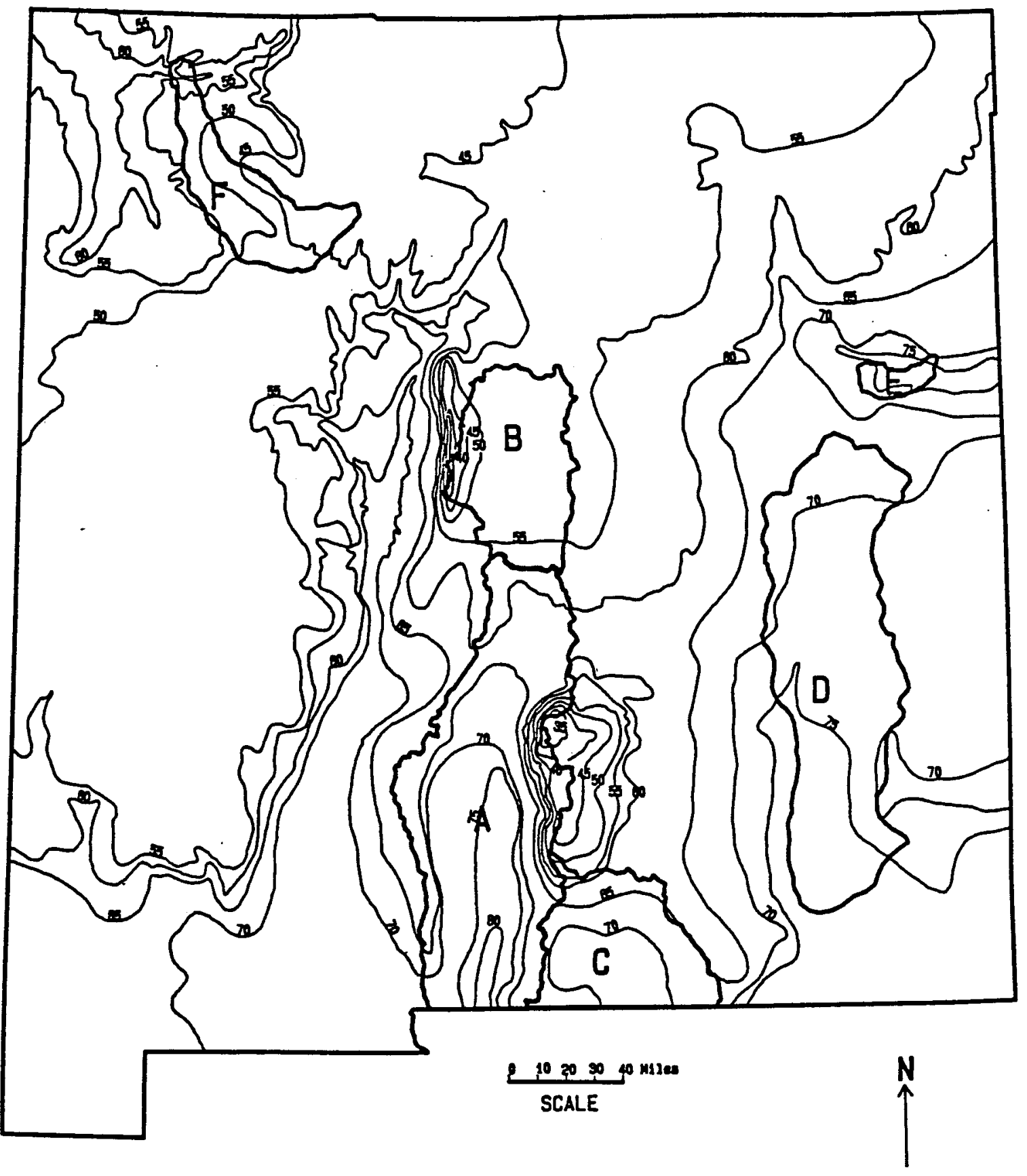

A - Tularosa Basín

B - Estancia Basin

C - Cron Flats Basin
D = Pecos Basin

E - Tucumcar 1 Basin

F - San Juan Basin

Figure A-5. Gross annual lake evaporation (in in.) showing study areas in New Mexico 
APPENDIX B

GROUNDWATER CHARACTERISTICS FOR POTENTIAL PRODUCTION AREAS 


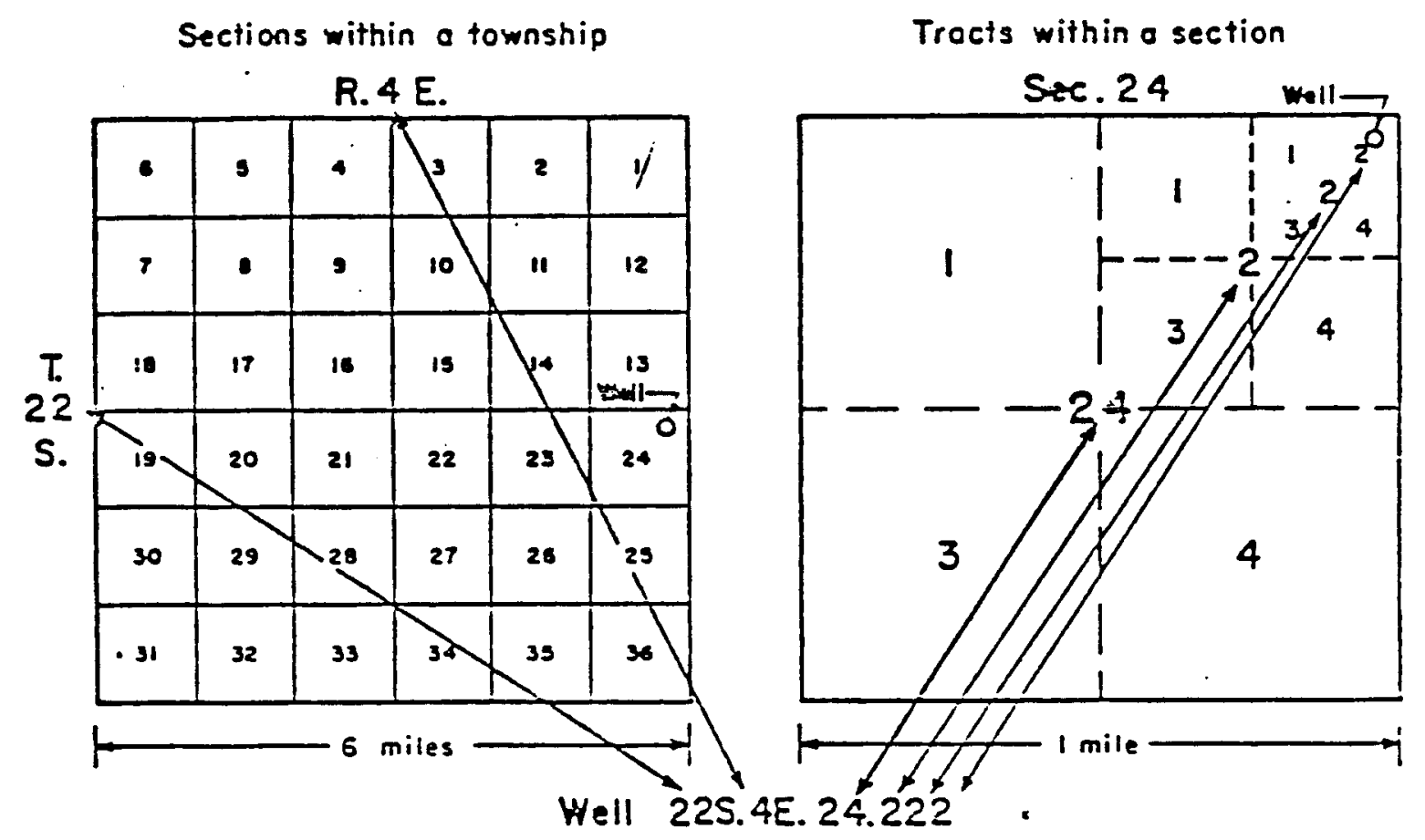

Figure B-1. Diagram showing systems of numbering wells 
Table B-1. Chemical Analyses of Water from Wells in the Tularosa Basin

\begin{tabular}{|c|c|c|c|c|c|c|c|c|c|c|c|c|c|c|c|c|c|c|c|c|c|}
\hline Local & $\mathrm{Wall}$ & Num ber & Depth & $\begin{array}{l}\text { Snica } \\
\text { (s102) }\end{array}$ & $\begin{array}{c}\text { Iron } \\
\text { (FE) }\end{array}$ & $\begin{array}{c}\text { Calcium } \\
(C A A)\end{array}$ & $\begin{array}{l}\text { Magne- } \\
\text { sium } \\
(M G)\end{array}$ & $\begin{array}{c}\text { Sodium } \\
\text { (WA) + } \\
\text { Potas- } \\
\text { sum } \\
\text { (k) }\end{array}$ & $\begin{array}{l}\text { Bicar- } \\
\text { bonate } \\
\text { (NCO3) }\end{array}$ & $\begin{array}{l}\text { Carbon- } \\
\text { ate } \\
\text { (c 0 3) }\end{array}$ & $\begin{array}{l}\text { Sulfate } \\
(\mathrm{S} 04)\end{array}$ & $\begin{array}{c}\text { Chloride } \\
\text { (CL) }\end{array}$ & $\begin{array}{l}\text { Fluo- } \\
\text { ride } \\
\text { (F) }\end{array}$ & $\begin{array}{l}\text { Mitrate } \\
\text { (N 03) }\end{array}$ & $\begin{array}{c}\text { Boron } \\
(R)^{\prime}\end{array}$ & $\begin{array}{l}\text { Dis- } \\
\text { solved } \\
\text { Solids }\end{array}$ & $\begin{array}{c}\text { Calcium } \\
\text { Magnesium m } \\
\text { Barduese }\end{array}$ & $\begin{array}{c}\text { Non- } \\
\text { Carbonate } \\
\text { Hardness }\end{array}$ & $\begin{array}{c}\text { Specific } \\
\text { Conductance } \\
\text { (microm ohos) } \\
\text { (25 Deg C) }\end{array}$ & PM & $\begin{array}{c}\text { Tempera- } \\
\text { ture } \\
\text { (Deg C) }\end{array}$ \\
\hline $17 \mathrm{~s}$ & 85 & 13.231 & 110 & - & - & 965.0 & 3360.0 & 12600 & 200 & - & 9280 & 24000.00 & - & - & - & 50300 & 16200 & 16000 & 61700 & 6.7 & - \\
\hline $17 \mathrm{~s}$ & $8 \mathrm{E}$ & 13.311 & 160 & 327.0 & - & 3070.0 & 1715.0 & 9900 & - & - & 1940 & 15000.00 & - & - & - & 32000 & 14500 & 14400 & - & 7.6 & - \\
\hline $17 \mathrm{~S}$ & $9 \mathrm{E}$ & 1.112 & 145 & - & - & - & - & - & - & - & 1260 & 356.00 & - & - & - & 2620 & - & - & 3310 & - & - \\
\hline $17 \mathrm{~s}$ & $9 E$ & 1.141 & - & - & - & - & - & - & - & - & 1670 & 720.00 & - & - & - & 3900 & - & - & 4930 & . & - \\
\hline $17 \mathrm{~s}$ & $9 \mathrm{E}$ & 1.311 & 50 & - & - & 426.0 & 307.0 & 802 & 363 & - & 2680 & 878.00 & - & - & - & 5660 & - & - & a $\quad-$ & - & - \\
\hline $17 \mathrm{~s}$ & $9 \mathrm{E}$ & 1.440 & 104 & - & - & 262.0 & 137.0 & 233 & 104 & - & 1194 & 221.00 & - & - & - & 2516 & - & - & - & - & - \\
\hline $17 \mathrm{~s}$ & $9 E$ & 2.111 & 132 & - & - & - & - & - & - & - & 1180 & 432.00 & - & - & - & 2640 & - & - & 3410 & - & - \\
\hline $17 \mathrm{~s}$ & $9 \mathrm{E}$ & 2.300 & 80 & - & - & 316.0 & 149.0 & 470 & - & 134 & 1472 & 465.00 & - & - & - & 3288 & - & - & - & - & - \\
\hline $17 \mathrm{~s}$ & $9 \mathrm{E}$ & 3.100 & 65 & - & - & 252.0 & 80.0 & 339 & - & 104 & 1111 & 288.00 & - & - & - & 2933 & - & .. & - & - & - \\
\hline $17 \mathrm{~s}$ & $9 \mathrm{E}$ & 3.400 & 135 & - & - & - & - & - & - & - & - & - & - & - & - & 2584 & - & - & - & - & - \\
\hline $17 \mathrm{~s}$ & $9 \mathrm{E}$ & 4.300 & 130 & - & - & 252.0 & 126.0 & 331 & - & 119 & 915 & 510.00 & - & - & - & 2476 & - & - & - & - & - \\
\hline $17 \mathrm{~s}$ & gE & 5.122 & 50 & - & - & - & - & 600 & 265 & - & 1350 & 910.00 & - & - & - & - & 1610 & 1390 & 5010 & . & - \\
\hline $17 \mathrm{~s}$ & $9 \mathrm{E}$ & 5.200 & 60 & - & - & 470.0 & 371.0 & 1211 & - & 37 & 2580 & 1897.00 & - & - & - & 7280 & - & - & - & - & - \\
\hline $17 \mathrm{~s}$ & $9 F$ & 8.744 & - & - & - & - & - & 341 & 95 & - & 2020 & 490.00 & - & - & - & • & 2130 & 2050 & 4370 & - & - \\
\hline $17 \mathrm{~S}$ & $9 \mathrm{E}$ & 8.400 & 100 & - & - & 521.0 & 169.0 & 517 & - & 53 & 2097 & 620.00 & - & - & - & 4740 & - & - & - & - & - \\
\hline $17 \mathrm{~s}$ & $9 E$ & 10.000 & 32 & - & - & 413.0 & 223.0 & 365 & - & 102 & 1977 & 865.00 & - & - & - & 3800 & - & - & - & . & - \\
\hline $17 \mathrm{~s}$ & $9 E$ & 12.422 & 200 & - & - & - & - & - & - & - & 774 & 196.00 & - & - & - & 1720 & - & - & 2150 & . & - \\
\hline $17 \mathrm{~s}$ & $9 \mathrm{E}$ & 12.422 & 270 & - & - & - & - & - & 203 & - & 814 & 215.00 & - & - & - & - & 1100 & 934 & 2210 & 7.1 & 119.4 \\
\hline $17 \mathrm{~S}$ & $9 i$ & 12.433 & 165 & - & - & - & - & 109 & 214 & - & 700 & 140.00 & - & 6.3 & - & - & 870 & 694 & 1850 & . & - $\quad-$ \\
\hline $17 \mathrm{~s}$ & $9 E$ & 13.244 & 310 & 16.0 & - & 131.0 & 63.0 & 95 & 176 & - & 487 & 96.00 & .30 & 5.2 & - & 980 & 586 & 442 & 1380 & . & - \\
\hline 175 & $9 E$ & 13.244 & 310 & 16.0 & - & 131.0 & 63.0 & 95 & 176 & - & 487 & 96.00 & .30 & 5.2 & - & 980 & 586 & 442 & 1380 & . & - \\
\hline $17 \mathrm{~S}$ & $9 E$ & 13.244 & 120 & 14.0 & - & 117.0 & 61.0 & 94 & 130 & 7 & 507 & 88.00 & .30 & 5.6 & - & 938 & 543 & 425 & 1380 & . & - \\
\hline $17 \mathrm{~S}$ & $9 \mathrm{E}$ & 13.400 & 85 & - & - & 114.0 & 61.0 & 37 & - & 109 & 340 & 55.00 & - & - & - & 821 & - & - & - & . & - \\
\hline $17 \mathrm{~s}$ & $9 \mathrm{E}$ & 14.422 & - & - & - & - & - & 95 & 205 & - & 652 & 141.00 & - & - & - & - & 840 & 672 & 1830 & . & - \\
\hline $17 \mathrm{~s}$ & $9 E$ & 19.240 & 62 & - & - & 755.0 & 750.0 & 1482 & 302 & 0 & 3841 & 2841.00 & - & - & - & 11640 & - & - & - & . & - \\
\hline $17 \mathrm{~s}$ & $9 \mathrm{E}$ & 23.310 & 85 & - & - & 241.0 & 120.0 & 201 & 213 & - & 976 & 244.0 & - & - & - & 2140 & - & - & - & . & - \\
\hline $17 \mathrm{~s}$ & $9 E$ & $23.310 A$ & 50 & - & - & 525.0 & 184.0 & 392 & 343 & - & 1949 & 439.0 & - & - & - & 3760 & - & - & - & . & - \\
\hline
\end{tabular}


Table B-1. Chemical Analyses of Water from Wells in the Tularosa Basin (Continued)

\begin{tabular}{|c|c|c|c|c|c|c|c|c|c|c|c|c|c|c|c|c|c|c|c|c|c|}
\hline Local & $\mathrm{W}$ all & lumber & Depth & $\begin{array}{l}\text { Silica } \\
\text { (S102) }\end{array}$ & $\begin{array}{l}\text { Iron } \\
\text { (FE) }\end{array}$ & $\begin{array}{l}\text { Calcium } \\
(\mathrm{CA})\end{array}$ & $\begin{array}{c}\text { Magne- } \\
\text { suum } \\
(M G)\end{array}$ & $\begin{array}{c}\text { Sodium } \\
\text { (KA) + } \\
\text { Potas- } \\
\text { sum m } \\
\text { (k) }\end{array}$ & $\begin{array}{l}\text { Bicar- } \\
\text { bonate } \\
\text { (WC 03) }\end{array}$ & $\begin{array}{c}\text { Carbon- } \\
\text { ate } \\
\left(\begin{array}{c}C \\
0\end{array}\right)\end{array}$ & $\begin{array}{l}\text { Sulfate } \\
\text { (S04) }\end{array}$ & $\begin{array}{c}\text { Chloride } \\
\text { (CL) }\end{array}$ & $\begin{array}{l}\text { Fluo- } \\
\text { ride } \\
\text { (F) }\end{array}$ & $\begin{array}{l}\text { Mitrate } \\
\text { (N 03) }\end{array}$ & $\begin{array}{c}\text { Boron } \\
\text { (R) }\end{array}$ & $\begin{array}{c}\text { Dis- } \\
\text { solved } \\
\text { Solids }\end{array}$ & $\begin{array}{c}\text { Calcium } \\
\text { Magnesium } \\
\text { Barduese }\end{array}$ & $\begin{array}{c}\text { Mon- } \\
\text { Carbonate } \\
\text { Hardness }\end{array}$ & $\begin{array}{c}\text { Specific } \\
\text { Conductance } \\
\text { (microm ohos) } \\
\text { (25 Deg C) }\end{array}$ & PM & $\begin{array}{c}\text { Tempera- } \\
\text { ture } \\
(\text { Beg }())\end{array}$ \\
\hline 175 & $8 \mathrm{E}$ & 5.431 & 892 & - & - & 719.0 & 192.0 & 1926 & 117 & - & 2970 & 2540.00 & - & - & - & 8406 & 2585 & - & - & - & - \\
\hline $17 \mathrm{~s}$ & $8 \mathrm{E}$ & 5.431 & 892 & 50.0 & 0 & 759.0 & 288.9 & - & - & - & 3033 & 3450.00 & - & - & - & 7580 & - & - & - & - & - \\
\hline $17 \mathrm{~s}$ & $9 E$ & 5.431 & 892 & 3.6 & 947.0 & 89.0 & - & - & - & 3115 & 2880.00 & - & - & - & 9111 & - & - & - & - & - & - \\
\hline $17 \mathrm{~S}$ & $9 \mathrm{E}$ & 5.431 & 892 & - & - & - & - & - & 120 & - & - & 2670.00 & - & - & - & - & - & - & 11700 & - & - \\
\hline $17 \mathrm{~s}$ & $9 \mathrm{E}$ & 5.431 & 892 & - & - & - & 1662.0 & 2100 & 78 & 32 & 2150 & 4218.00 & - & - & - & 10240 & - & - & 16000 & 7.1 & - \\
\hline $17 \mathrm{~S}$ & $9 E$ & 12.113 & 40 & - & - & - & - & 550 & 86 & - & 2070 & 865.00 & - & - & - & - & 2250 & 2180 & 3510 & - & - \\
\hline $17 \mathrm{~s}$ & $9 \mathrm{E}$ & 1.200 & 71 & - & - & 108.0 & 54.0 & 83 & - & 114 & 330 & 100.00 & - & - & - & 788 & - & - & - & - & - \\
\hline $17 \mathrm{~S}$ & 9[ & 1.400 & 82 & - & - & 180.0 & 107.0 & 69 & - & 108 & 421 & 299.00 & - & - & - & 1468 & - & - & - & - & - \\
\hline $17 \mathrm{~s}$ & $9 E$ & 10.443 & 35 & - & - & 312.0 & 290.0 & 392 & - & - & 1811 & 566.00 & - & - & - & 3751 & - & - & - & - & - \\
\hline $17 \mathrm{~s}$ & $9 \mathrm{E}$ & 10.443 & 40 & - & - & - & - & 441 & 200 & - & 1720 & 520.00 & - & - & - & - & 1730 & 1570 & 4280 & - & - \\
\hline 175 & $9 \mathrm{E}$ & 11.144 & & 35.0 & - & 480.0 & 326.0 & 443 & 224 & - & 1830 & 1000.00 & - & 6.3 & - & 4230 & 2540 & 2360 & - & 7.3 & - \\
\hline $17 \mathrm{~s}$ & $9 \mathrm{E}$ & 11.213 & 100 & 39.0 & - & 99.0 & 52.0 & 53 & 236 & 0 & 306 & 44.00 & - & .7 & - & 710 & 460 & 266 & 1030 & 7.5 & - \\
\hline $17 \mathrm{~S}$ & $9 \mathrm{E}$ & 11.400 & 50 & - & - & 204.0 & 179.0 & 286 & - & 111 & 1183 & 321.00 & - & - & - & 2724 & - & - & - & - & - \\
\hline $17 \mathrm{~s}$ & $9 \mathrm{E}$ & 11.412 & & - & - & - & - & - & - & - & 302 & 43.00 & - & - & - & - & - & - & 1020 & - & - \\
\hline $17 \mathrm{~s}$ & $9 \mathrm{E}$ & 11.431 & 103 & - & - & 216.0 & 116.0 & 150 & 244 & - & 827 & 199.00 & - & - & - & 1804 & - & - & + & - & - \\
\hline $17 \mathrm{~s}$ & $9 \mathrm{E}$ & 14.300 & & - & - & 156.0 & 97.0 & 126 & - & 125 & 558 & 194.00 & - & - & - & 1452 & - & - & - & - & - \\
\hline $17 \mathrm{~S}$ & $9 \mathrm{E}$ & 23.442 & & - & : & - & - & - & 222 & - & 1390 & 302.00 & - & - & - & - & 1510 & 1330 & 3300 & 7.8 & - \\
\hline $17 \mathrm{~s}$ & $9 \mathrm{E}$ & 26.311 & 50 & - & - & 611.0 & 304.0 & 829 & - & - & 3016 & 953.00 & - & - & - & 6912 & - & - & - & - & - \\
\hline $17 \mathrm{~S}$ & $9 \mathrm{E}$ & 26.311 & 100 & - & - & - & - & 618 & 156 & - & 2690 & 1060.00 & - & - & - & - & 33080 & 2950 & 6860 & - & - \\
\hline $17 \mathrm{~S}$ & $9 \mathrm{E}$ & 27.422 & & 68.0 & - & 610.0 & 311.0 & 753 & 146 & - & 2610 & - & - & 77.0 & - & 5590 & 2000 & 2680 & 7130 & 7.3 & 23.0 \\
\hline $17 \mathrm{~S}$ & $9 \mathrm{E}$ & 36.222 & 91 & 14.0 & - & 242.0 & 169.0 & 127 & 106 & 0 & 1210 & 162.00 & - & .4 & - & t980 & 1300 & 1210 & 2500 & 7.1 & - \\
\hline $17 \mathrm{~S}$ & $9 E$ & 25.212 & 236 & 15.0 & 0 & 96.0 & 34.0 & 36 & 221 & 0 & 221 & 36.00 & .30 & 1.6 & - & 540 & 380 & 199 & 817 & 7.3 & 20.0 \\
\hline $17 \mathrm{~S}$ & $9 E$ & 25.212 & 236 & 20,0 & 0 & 100.0 & 35.0 & - & 216 & 0 & 227 & 36.00 & .40 & 2.0 & - & 560 & 394 & 217 & 846 & 7.3 & 18.3 \\
\hline $17 \mathrm{~S}$ & $9 E$ & 25.212 & 236 & 21.0 & 0 & 92.0 & 38.0 & 32 & 220 & 0 & 210 & 38.00 & .30 & 2.4 & - & 542 & 386 & 206 & 831 & 7.5 & 21.1 \\
\hline 175 & $9 \mathrm{E}$ & 25.213 & 243 & - & - & 95.0 & 36.0 & 41 & 227 & - & 238 & 34.00 & - & 1.2 & - & 559 & 393 & 207 & 862 & 7.8 & - \\
\hline 175 & $9 \varepsilon$ & 25.213 & 243 & 20.0 & 0 & 100.0 & 370.0 & 35 & 219 & 0 & 231 & 38.00 & .30 & 1.4 & - & 571 & 400 & 220 & 862 & 7.4 & 20.0 \\
\hline $17 \mathrm{~S}$ & $9 \mathrm{E}$ & 25.213 & 243 & - & 0 & 95.0 & 41.0 & 45 & 220 & 0 & 249 & 42.00 & .30 & 1.7 & - & 604 & 404 & 224 & 891 & 8.1 & 20.0 \\
\hline
\end{tabular}


Taile B-1. Chemical Analyses of Water from Wells in the Tularosa Basin (Continued)

\begin{tabular}{|c|c|c|c|c|c|c|c|c|c|c|c|c|c|c|c|c|c|c|c|c|c|}
\hline Local & wall & Number & Depth & $\begin{array}{l}\text { Silica } \\
\text { (S102) }\end{array}$ & $\begin{array}{l}\text { Iron } \\
\text { (FE) }\end{array}$ & $\begin{array}{l}\text { Calcium } \\
(\mathrm{CA})\end{array}$ & $\begin{array}{l}\text { Magne- } \\
\text { slum } \\
\text { (MG) }\end{array}$ & $\begin{array}{l}\text { Sodium } \\
(\text { NA A) + } \\
\text { Potas- } \\
\text { sium } \\
(k)\end{array}$ & $\begin{array}{l}\text { Bicar- } \\
\text { bonate } \\
\text { (NC 03) }\end{array}$ & $\begin{array}{l}\text { Carbon- } \\
\text { ate } \\
\text { (C 0 3) }\end{array}$ & $\begin{array}{l}\text { Sulfate } \\
\text { (S04) }\end{array}$ & $\begin{array}{l}\text { Chloride } \\
\text { (CLL) }\end{array}$ & $\begin{array}{l}\text { Fluo- } \\
\text { ride } \\
\text { (F) }\end{array}$ & $\begin{array}{c}\text { Mitrate } \\
\text { (N03) }\end{array}$ & $\begin{array}{c}\text { Boron } \\
(R)\end{array}$ & $\begin{array}{l}\text { Dis- } \\
\text { solved } \\
\text { Solids }\end{array}$ & $\begin{array}{c}\text { Calciun } \\
\text { Magnesium } \\
\text { Barduese }\end{array}$ & $\begin{array}{l}\text { Non- } \\
\text { Carbonate } \\
\text { Hardness }\end{array}$ & $\begin{array}{c}\text { Specific } \\
\text { Conductance } \\
\text { (microw ohos) } \\
\text { (25 Deg C) }\end{array}$ & PM & $\begin{array}{l}\text { Tempera- } \\
\text { ture } \\
\text { (0eg C) }\end{array}$ \\
\hline $17 \mathrm{~s}$ & $9 \mathrm{E}$ & 23.333 & 208 & - & - & - & - & - & 244 & - & 2000 & 545.00 & - & - & - & - & 2420 & - & 4720 & - & - \\
\hline $17 \mathrm{~s}$ & $9 \mathrm{E}$ & 23.333 & 107 & - & - & - & - & - & 376 & - & - & 4470.00 & - & - & - & - & 5750 & - & 15800 & - & - \\
\hline $17 \mathrm{~s}$ & $9 \mathrm{E}$ & 23.431 & 300 & - & - & - & - & - & 155 & 0 & 700 & 110.00 & - & - & - & - & 740 & - & 1700 & - & - \\
\hline $17 \mathrm{~s}$ & $9 \mathrm{E}$ & 23.431 & 390 & 15.0 & - & 176.0 & 69.0 & 126 & 155 & - & 686 & 110.00 & .60 & 7.9 & - & 1270 & 730 & 603 & 1700 & - & - \\
\hline $17 \mathrm{~s}$ & $9 \mathrm{E}$ & 23.431 & 51 & - & - & - & - & - & 350 & 0 & 1000 & 161.00 & - & - & - & - & 1220 & - & 2590 & - & - \\
\hline $17 \mathrm{~s}$ & 95 & 24.142 & 312 & - & - & - & - & - & 192 & 0 & 375 & 120.00 & - & - & - & - & 590 & - & 1410 & - & - \\
\hline $17 \mathrm{~s}$ & $9 E$ & 24.142 & 312 & 20.0 & - & 141.0 & 63.0 & 86 & 192 & - & 446 & 120.00 & .20 & 7.6 & - & 978 & 611 & 454 & 1410 & - & - \\
\hline $17 \mathrm{~s}$ & $9 E$ & 24.142 & 80 & - & - & - & - & - & 222 & o & 350 & 113.00 & - & - & - & - & 532 & - & 1320 & - & - \\
\hline $17 \mathrm{~s}$ & $9 \mathrm{E}$ & 24.222 & 314 & 15.0 & - & 100.0 & 40.0 & 60 & 242 & 0 & 240 & 45.00 & .30 & 1.8 & - & 622 & 418 & 220 & 908 & - & - \\
\hline $17 \mathrm{~s}$ & $9 \varepsilon$ & 24.222 & 314 & - & - & - & - & - & 190 & 0 & 250 & 54.00 & - & - & - & - & 424 & 262 & 908 & - & - \\
\hline $17 \mathrm{~s}$ & $9 \mathrm{E}$ & 24.222 & 105 & - & - & - & - & - & 242 & 0 & 180 & 45.00 & - & - & - & - & 416 & 218 & 894 & - & - \\
\hline $17 \mathrm{~S}$ & $9 E$ & 24.342 & 231 & 20.0 & - & 99.0 & 46.0 & 33 & 218 & - & 260 & 41.00 & .20 & 1.4 & - & 607 & 436 & 259 & 920 & 7.3 & - \\
\hline $17 \mathrm{~s}$ & $9 E$ & 24.342 & 231 & 20.0 & .03 & 106.0 & 43.0 & 44 & 217 & 0 & 279 & 47.00 & .30 & 2.1 & - & 648 & 442 & 264 & 961 & 7.3 & 20.0 \\
\hline $17 \mathrm{~s}$ & $9 E$ & 24.342 & 211 & - & 0 & 108.0 & 39.0 & 40 & 218 & 0 & 250 & 46.00 & .30 & 1.8 & - & 619 & 428 & 250 & 927 & 7.4 & 20.0 \\
\hline $17 \mathrm{~s}$ & $9 \mathrm{E}$ & 24.342 & 231 & 21.0 & 0 & 104.0 & 43.0 & 30 & 220 & 0 & 259 & 49.00 & .20 & 2.1 & - & 624 & 438 & 258 & 954 & 7.1 & 22.8 \\
\hline $17 \mathrm{~s}$ & $9 \mathrm{E}$ & 24.343 & 255 & 24.0 & - & 109.0 & 63.0 & 21 & 212 & - & 300 & 56.00 & .20 & 3.0 & 0 & 688 & 531 & 358 & 1020 & 7.3 & - \\
\hline $17 \mathrm{~s}$ & $.9 \mathrm{E}$ & 24.343 & 255 & 22.0 & 0 & 115.0 & 41.0 & - & 210 & 0 & 293 & 52.00 & .40 & 2.7 & - & 675 & 454 & 282 & 1000 & 7.3 & 20.0 \\
\hline $17 \mathrm{~s}$ & $9 \mathrm{E}$ & 24.343 & 255 & 22.0 & 0 & 108.0 & 46.0 & 45 & 212 & 0 & 289 & 56.00 & .30 & 3.0 & - & 673 & 460 & 286 & 1020 & 7.7 & 21.1 \\
\hline $17 \mathrm{~S}$ & $9 \mathrm{E}$ & 25.111 & 73 & - & . & - & - & 48 & 242 & - & 316 & 53.00 & - & 2.4 & - & - & 500 & 302 & 1100 & - & - \\
\hline $17 \mathrm{~s}$ & $9 E$ & 25.112 & 250 & . & - & 105.0 & 100.0 & - & - & - & 360 & 86.00 & - & - & - & 798 & 570 & - & - & - & - \\
\hline $17 \mathrm{~s}$ & $9 \mathrm{E}$ & 25.123 & 80 & - & - & - & - & - & 238 & 0 & 300 & 50.00 & - & - & - & - & 440 & - & 1024 & - & - \\
\hline $17 \mathrm{~s}$ & $9 E$ & 25.123 & 312 & 21.0 & - & 105.0 & 47.0 & 66 & 185 & - & 336 & 65.00 & .30 & 4.7 & - & 736 & 456 & 304 & 1070 & - & - \\
\hline $17 \mathrm{~s}$ & $9 \mathrm{E}$ & 25.123 & 312 & - & - & - & - & - & 185 & 0 & 350 & 65.00 & - & - & - & - & 435 & - & - 1070 & - & - \\
\hline $17 \mathrm{~s}$ & 95 & 25.132 & 250 & - & - & 162.0 & 88.0 & - & - & - & 326 & 68.00 & - & - & - & 730 & 510 & - & - & - & - \\
\hline $17 \mathrm{~s}$ & $9 \mathrm{E}$ & 25.200 & - & - & - & 186.0 & 86.0 & 111 & - & 128 & 481 & 244.00 & - & - & - & 1363 & - & - & - & - & - \\
\hline $17 \mathrm{~s}$ & gE & 25.212 & 236 & 19.0 & - & 89.0 & 47.0 & 15 & 217 & - & 213 & 33.00 & 20.00 & 1.4 & - & 525 & 416 & 238 & 810 & 7.3 & - \\
\hline
\end{tabular}


Table B-1. Chemical Analyses of Water from Wells in the Tularosa Basin (Concluded)

\begin{tabular}{|c|c|c|c|c|c|c|c|c|c|c|c|c|c|c|c|c|c|c|c|c|c|}
\hline Local & Wall & Vumber & Depth & $\begin{array}{l}\text { Siltica } \\
\text { (s102) }\end{array}$ & $\begin{array}{l}\text { Iron } \\
(\mathrm{FE})\end{array}$ & $\begin{array}{c}\text { Calclum min } \\
\text { (CA })\end{array}$ & $\begin{array}{l}\text { Magne- } \\
\text { sium } \\
\text { (M G) }\end{array}$ & $\begin{array}{l}\text { Sodium } \\
\text { (NA) + } \\
\text { Potas- } \\
\text { slum } \\
\text { (k) }\end{array}$ & $\begin{array}{l}\text { Bicar- } \\
\text { bonate } \\
\text { (NCO3) }\end{array}$ & $\begin{array}{l}\text { Carton- } \\
\text { ate } \\
\text { (C. } 03 \text { ) }\end{array}$ & $\begin{array}{l}\text { Sulfate } \\
\text { (S04) }\end{array}$ & $\begin{array}{l}\text { Chloride } \\
\text { (CL) }\end{array}$ & $\begin{array}{l}\text { Fluo- } \\
\text { ride } \\
(\mathrm{F})\end{array}$ & $\begin{array}{l}\text { Mitrate } \\
\left(\begin{array}{l}(103)\end{array}\right.\end{array}$ & $\begin{array}{c}\text { Boron } \\
(\&)\end{array}$ & $\begin{array}{l}\text { Dis- } \\
\text { solved } \\
\text { Solids }\end{array}$ & $\begin{array}{c}\text { Calcium } \\
\text { Magnestum } \\
\text { Barduese }\end{array}$ & $\begin{array}{c}\text { Non- } \\
\text { Carbonate } \\
\text { Hardness }\end{array}$ & $\begin{array}{c}\text { Specific } \\
\text { Conductance } \\
\text { (micro mohos) } \\
\text { (25 Deg C) }\end{array}$ & PM & $\begin{array}{c}\text { Tempera- } \\
\text { ture } \\
\text { (Deg } \mathrm{C})\end{array}$ \\
\hline $17 \mathrm{~s}$ & $8 \mathrm{E}$ & 25.213 & 271 & 21.0 & .01 & 100.0 & 19.0 & 38 & 217 & 0 & 245 & 41.00 & .20 & 1.6 & - & 593 & 410 & 232 & 887 & 7.4 & 20.0 \\
\hline $17 \mathrm{~s}$ & $8 E$ & 25.222 & 271 & - & - & 86.0 & 40.0 & 31 & 223 & - & 212 & 30.00 & - & 1.5 & - & 510 & 379 & 196 & 805 & 7.8 & - \\
\hline $17 \mathrm{~s}$ & $9 E$ & 25.212 & 271 & 19.0 & .10 & 97 & 36.0 & 33 & 217 & 0 & 272 & 44.00 & .40 & 1.7 & - & 550 & 392 & 214 & 840 & 7.2 & 20.0 \\
\hline $17 \mathrm{~s}$ & $9 \mathrm{E}$ & 25.222 & 271 & 20.0 & 0 & 98.0 & 34.0 & 34 & 216 & 0 & 223 & 35.00 & .30 & 1.6 & - & 552 & 386 & 209 & 833 & 7.4 & 20.0 \\
\hline 175 & $9 \mathrm{E}$ & 25.222 & 271 & 21.0 & 0 & 96.0 & 37.0 & 35 & 216 & 0 & 224 & 40.00 & .30 & 2.1 & - & 561 & 392 & 215 & 857 & 7.5 & 21.1 \\
\hline $17 \mathrm{~s}$ & $9 \mathrm{E}$ & 25.300 & 45 & - & - & 197.0 & 94.0 & 106 & 301 & - & 689 & 104.00 & - & - & - & 1463 & - & . & - & - & - \\
\hline $17 \mathrm{~s}$ & 9E & 25.324 & 517 & 19.0 & - & 81.0 & 39.0 & 68 & 179 & - & 201 & 48.00 & 4.00 & 2.5 & - & 427 & 362 & 216 & 946 & 7.8 & - \\
\hline $17 \mathrm{~s}$ & $9 \mathrm{E}$ & 25.324 & 512 & - & - & - & - & - & 179 & 0 & 300 & 48.00 & - & - & - & - & 234 & - & - & 946 & - \\
\hline $17 \mathrm{~s}$ & $9 \mathrm{E}$ & 25.324 & 80 & - & - & - & - & - & 224 & 0 & 325 & 107.00 & - & - & - & - & 300 & - & 1260 & - & - \\
\hline 175 & $9 \mathrm{E}$ & 25.323 & & 23.0 & 0 & 102.0 & 40.0 & 31 & 218 & 0 & 249 & 36.00 & .40 & 1.8 & 588 & 420 & 242 & 884 & 7.4 & 20.0 & - \\
\hline 175 & $9 \mathrm{E}$ & 25.323 & & 23.0 & 0 & 107.0 & 39.0 & 49 & 213 & 0 & 200 & 41.00 & .40 & 1.7 & - & 654 & 428 & 254 & 952 & 7.1 & 20.0 \\
\hline $17 \mathrm{~s}$ & $9 \varepsilon$ & $25.343 \AA$ & & 22.0 & .01 & 98.0 & 41.0 & 41 & 221 & 0 & 259 & 36.00 & .40 & $1 / 6$ & - & 506 & 412 & 231 & 903 & 7.4 & 20.0 \\
\hline $17 \mathrm{~s}$ & $9 \mathrm{E}$ & $25.343 \mathrm{~A}$ & & 23.0 & 0 & 105.0 & 40.0 & 42 & 210 & 0 & 271 & 43.00 & .40 & 1.0 & - & 629 & 424 & 254 & 930 & 7.5 & 20.0 \\
\hline $17 \mathrm{~s}$ & $9 E$ & 25.444 & 307 & 19.0 & - & 48.0 & 28.0 & 184 & 184 & 0 & 203 & 176.00 & .90 & .8 & - & 745 & 214 & 64 & 1230 & - & - \\
\hline 175 & $9 \mathrm{E}$ & 25.484 & 80 & 20.0 & - & 122.0 & 52.0 & 148 & 262 & 0 & 290 & 222.00 & .20 & 2.4 & - & 997 & 510 & 304 & 1570 & - & - \\
\hline $17 \mathrm{~s}$ & $9 \bar{E}$ & 26.200 & 40 & - & - & 186.0 & 119.0 & 127 & - & 134 & 720 & 177.00 & - & - & - & 1680 & - & - & - & - & - \\
\hline $17 \mathrm{~s}$ & $9 \mathrm{E}$ & 28.242 & & - & - & - & - & - & - & - & 344 & 136.00 & - & - & - & - & - & - & 1340 & - & - \\
\hline $17 \mathrm{~s}$ & $9 \mathrm{E}$ & 24.414 & 312 & - & - & - & - & - & 103 & 0 & 270 & 41.00 & - & - & - & - & 330 & 238 & 868 & - & - \\
\hline 175 & gE & 26.414 & 75 & - & - & - & - & - & 252 & 0 & 275 & 45.00 & - & - & - & - & 450 & 244 & 984 & - & - \\
\hline $17 \mathrm{~s}$ & $9 \mathrm{E}$ & 24.481 & 100 & - & - & - & - & - & 210 & - & 1200 & 168.00 & - & - & - & - & 1400 & - & 2730 & - & - \\
\hline 175 & $9 \mathrm{E}$ & 28.481 & 209 & - & - & - & - & - & 194 & - & 700 & 123.00 & - & - & - & - & 830 & - & 1790 & - & - \\
\hline $17 \mathrm{~s}$ & $9 \mathrm{E}$ & 35.242 & 298 & 32.0 & - & 110.0 & 51.0 & 10 & 223 & - & 299 & 53.00 & .20 & 2.0 & - & 687 & 484 & 302 & 10101 & - & - \\
\hline 175 & $9 \mathrm{E}$ & 05.332 & 100 & 15.0 & - & 190.0 & 134.0 & - & - & - & 511 & 112.00 & - & - & - & 850 & 660 & - & - & 7.1 & - \\
\hline 175 & $9 \mathrm{E}$ & 35.332 & 100 & - & - & - & - & 76 & 187 & - & 505 & 104.00 & - & - & - & - & 660 & 507 & 1480 & - & - \\
\hline $17 \mathrm{~s}$ & $9 \mathrm{E}$ & 05.444 & 297 & 34.0 & - & 95.0 & 48.0 & 59 & 20 & - & 32 & 41.00 & .40 & 1.0 & - & 703 & 434 & 268 & 1010 & - & - \\
\hline 175 & $9 \mathrm{E}$ & 05.414 & 312 & 26.0 & - & 89.0 & 37.0 & 63 & 183 & - & 240 & 41.00 & .60 & 1.4 & - & 386 & 324 & 174 & 868 & - & - \\
\hline
\end{tabular}


Table B-2. Chemical Analyses of Water from Wells and Springs in the Estancia Basin

\begin{tabular}{|c|c|c|c|c|c|c|c|c|c|c|c|c|c|}
\hline $\begin{array}{c}\text { Well } \\
\text { Locatton } \\
\text { Nunber }\end{array}$ & $\begin{array}{c}\text { Specific } \\
\text { Conductance } \\
\text { (on icrom hos } \\
\text { at } 25^{\circ} \mathrm{C} \text { ) } \\
\end{array}$ & $\begin{array}{l}\text { Snica } \\
\left(\mathrm{StO}_{2}\right)\end{array}$ & $\begin{array}{c}\text { Calclum } \\
\text { (Ca) }\end{array}$ & $\begin{array}{c}\text { Magnesium } \\
\text { (Mg) }\end{array}$ & $\begin{array}{l}\text { Sodium and } \\
\text { Potassiun } \\
(\text { Ma }+K)\end{array}$ & 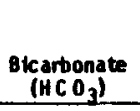 & $\begin{array}{l}\text { Sulfate } \\
\left(\mathrm{SO}_{1}\right)\end{array}$ & $\begin{array}{c}\text { Chlortde } \\
\text { (C) })\end{array}$ & $\begin{array}{c}\text { Floride } \\
(F)\end{array}$ & $\begin{array}{l}\text { Mitrate } \\
\left(\mathrm{MO}_{3}\right)\end{array}$ & $\begin{array}{c}\text { Otssolved } \\
\text { Solids }\end{array}$ & $\begin{array}{l}\text { Hardness } \\
\text { es } \\
\mathrm{CaCO}_{3}\end{array}$ & $\begin{array}{l}\text { Percent } \\
\text { Sodium }\end{array}$ \\
\hline $\begin{array}{l}\text { 4.9.6.400 } \\
4.9 .11 .112 \\
\text { Do. }\end{array}$ & $\begin{array}{r}597 \\
5,280 \\
8,630\end{array}$ & $=$ & $:$ & $=$ & $:$ & $\begin{array}{r}250 \\
65 \\
379\end{array}$ & $=$ & $\begin{array}{r}15 \\
450 \\
1,140\end{array}$ & $=$ & $:$ & $:$ & $=$ & $:$ \\
\hline $\begin{array}{l}\text { 4.9.11.112 } \\
\text { Do. } \\
\text { Do. }\end{array}$ & $\begin{array}{l}8,270 \\
8,540 \\
8,510\end{array}$ & $=$ & 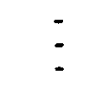 & ! & : & $3 i$ & $=$ & $\begin{array}{l}1,040 \\
1,070 \\
1,070\end{array}$ & 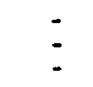 & $\vdots$ & $:$ & : & : \\
\hline $\begin{array}{l}\text { 4.9.11.312 } \\
\text { Do. } \\
4.9 .16 .131\end{array}$ & $\begin{array}{l}4,390 \\
4,440 \\
3,280\end{array}$ & $=$ & 137? & 213 & 812 & $\begin{array}{l}326 \\
340 \\
316\end{array}$ & $\begin{array}{c}1.400 \\
- \\
-\end{array}$ & $\begin{array}{l}580 \\
592 \\
193\end{array}$ & $\begin{array}{r}0.8 \\
-\end{array}$ & $\begin{array}{r}1.7 \\
-\end{array}$ & 3,110 & $\begin{array}{r}1,220 \\
:\end{array}$ & : \\
\hline $\begin{array}{l}\text { 4.10.2.1143 } \\
\text { 5.9.6.j11 } \\
\text { Do. }\end{array}$ & $\begin{array}{r}5,050 \\
533 \\
559\end{array}$ & $\begin{array}{l}24 \\
:\end{array}$ & 642 & 125: & 505 & $\begin{array}{l}570 \\
297 \\
297\end{array}$ & $\begin{array}{c}1,660 \\
:-\end{array}$ & $\begin{array}{r}685 \\
11 \\
10\end{array}$ & $\begin{array}{c}0.9 \\
:\end{array}$ & 7.1 & $\begin{array}{r}3,910 \\
:\end{array}$ & 2,070 & $\begin{array}{r}35 \\
-\end{array}$ \\
\hline $\begin{array}{l}5.9 .18 .400 \\
5.9 .18 .424 \\
5.10 .13 .443\end{array}$ & $\begin{array}{r}660 \\
650 \\
4,210\end{array}$ & $\begin{array}{l}22 \\
22 \\
20\end{array}$ & $\begin{array}{r}53 \\
58 \\
626\end{array}$ & $\begin{array}{r}41 \\
40 \\
152\end{array}$ & $\begin{array}{r}31 \\
24 \\
249\end{array}$ & $\begin{array}{r}359 \\
260 \\
92\end{array}$ & $\begin{array}{c}120 \\
121 \\
1,820\end{array}$ & $\begin{array}{r}12 \\
13 \\
524\end{array}$ & $\begin{array}{l}1.2 \\
1.2 \\
2.3\end{array}$ & $\begin{array}{l}1.1 \\
1.4 \\
16\end{array}$ & $\begin{array}{r}419 \\
408 \\
3,450\end{array}$ & $\begin{array}{r}300 \\
309 \\
2,190\end{array}$ & $\begin{array}{l}18 \\
15 \\
20\end{array}$ \\
\hline $\begin{array}{l}5.10 .28 .400 \\
6.9 .1 .300 \\
6.9 .2 .400\end{array}$ & $\begin{array}{l}7,250 \\
2,640 \\
3,060\end{array}$ & $\overline{24}$ & $\begin{array}{r}565 \\
228 \\
-\end{array}$ & $\begin{array}{r}483 \\
107 \\
-\end{array}$ & $\begin{array}{r}745 \\
226 \\
-\end{array}$ & $\begin{array}{r}262 \\
252 \\
-\end{array}$ & $\begin{array}{c}3,220 \\
780 \\
-\end{array}$ & $\begin{array}{r}1,020 \\
336 \\
420\end{array}$ & $\begin{array}{l}3.0 \\
1.1 \\
-\end{array}$ & $\begin{array}{r}2.3 \\
5.4 \\
-\end{array}$ & $\begin{array}{r}6,170 \\
1,830 \\
-\end{array}$ & $\begin{array}{r}3,400 \\
1,010 \\
-\end{array}$ & 33 \\
\hline $\begin{array}{l}\text { 6.9.9.222 } \\
\text { Do. } \\
\text { Do. }\end{array}$ & $\begin{array}{l}2,260 \\
2,190 \\
2,280\end{array}$ & $\overline{-}$ & $\overline{-}$ & $:$ & $:$ & 368 & $:$ & $\begin{array}{l}300 \\
286 \\
302\end{array}$ & $:$ & $:$ & 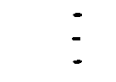 & $:$ & $:$ \\
\hline $\begin{array}{l}\text { Do. } \\
6.9 .11 \\
6.9 .11 .211\end{array}$ & $\begin{array}{l}2,420 \\
1,800 \\
2,300\end{array}$ & 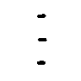 & $17 \overline{-}$ & 69 & 122 & $\begin{array}{l}29 \overline{5} \\
265\end{array}$ & 462 & $\begin{array}{l}325 \\
190 \\
285\end{array}$ & 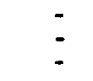 & $\overline{-}$ & 1,160 & 725 & 27 \\
\hline $\begin{array}{l}6.9 .12 \\
6.9 .28 .333 \\
6.9 .33 .333\end{array}$ & $\begin{array}{l}9,450 \\
4,380 \\
1,980\end{array}$ & : & - & - & : & $\begin{array}{r}322 \\
903 \\
-\end{array}$ & $=$ & $\begin{array}{r}1,440 \\
244 \\
79\end{array}$ & : & : & 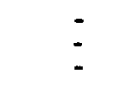 & $\dot{-}$ & 5 \\
\hline $\begin{array}{l}\text { Do. } \\
\text { Do. } \\
\text { Do. }\end{array}$ & $\begin{array}{l}2,010 \\
1,900 \\
1,840\end{array}$ & : & $=$ & $:$ & - & 518 & $=$ & $\begin{array}{l}81 \\
86 \\
72\end{array}$ & : & : & 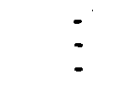 & $:$ & $\overline{-}$ \\
\hline $\begin{array}{l}6.10 .6 .3009 \\
00.0 \\
6.107 .112\end{array}$ & $\begin{array}{l}3,290 \\
3,010 \\
2,370\end{array}$ & 22 & $\begin{array}{l}352 \\
274 \\
219\end{array}$ & $\begin{array}{r}138 \\
149 \\
94\end{array}$ & $\begin{array}{l}238 \\
215 \\
194\end{array}$ & $\begin{array}{l}222 \\
284 \\
256\end{array}$ & $\begin{array}{l}1,180 \\
948 \\
686\end{array}$ & $\begin{array}{l}385 \\
380 \\
302\end{array}$ & $\begin{array}{l}1.4 \\
1.2 \\
0.9\end{array}$ & $\begin{array}{l}8.2 \\
5.0 \\
2.7\end{array}$ & $\begin{array}{l}2,410 \\
2,130 \\
1,620\end{array}$ & $\begin{array}{r}1,450 \\
1,300 \\
933\end{array}$ & 26 \\
\hline $\begin{array}{l}\text { Do. } \\
\text { 6.10.8 } \\
6.10 .8 .112\end{array}$ & $\begin{array}{l}2,360 \\
2,680 \\
2,660\end{array}$ & 22 & 248 & 126 & 189 & $\begin{array}{l}260 \\
276 \\
272\end{array}$ & 818 & $\begin{array}{l}285 \\
328 \\
325\end{array}$ & 1.4 & 4.6 & 1,870 & 1,140 & 27 \\
\hline $\begin{array}{l}6.10 .27 .400 \\
6.10 .32 .200 \\
6.10 .32 .222\end{array}$ & $\begin{array}{l}3,500 \\
4,070 \\
4,020\end{array}$ & $\begin{array}{l}- \\
20\end{array}$ & $\begin{array}{l}300 \\
360 \\
366\end{array}$ & $\begin{array}{l}195 \\
246 \\
251\end{array}$ & $\begin{array}{l}260 \\
311 \\
283\end{array}$ & $\begin{array}{l}266 \\
330 \\
335\end{array}$ & $\begin{array}{l}1,200 \\
1,520 \\
1,500\end{array}$ & $\begin{array}{l}455 \\
515 \\
508\end{array}$ & $\begin{array}{l}2.0 \\
2.1 \\
2.3\end{array}$ & $\begin{array}{l}1.0 \\
0.9 \\
1.4\end{array}$ & $\begin{array}{l}2,540 \\
3,210 \\
3,100\end{array}$ & $\begin{array}{l}1,550 \\
1,910 \\
1,940\end{array}$ & 24 \\
\hline
\end{tabular}


Table B-3. Chemical Analyses of Water from Wells in the Crow Flats Basin

\begin{tabular}{|c|c|c|c|c|c|c|c|c|c|c|c|c|c|c|c|c|c|c|}
\hline \multirow[b]{2}{*}{$\begin{array}{l}\text { Locazion } \\
\text { Number }\end{array}$} & \multirow[b]{2}{*}{$\begin{array}{c}\text { Tempera } \\
\text { ture } \\
{ }^{\circ} \mathrm{F}\end{array}$} & \multicolumn{9}{|c|}{ Chemical Constituents } & \multicolumn{2}{|c|}{$\begin{array}{l}\text { Dissolved } \\
\text { Solids }\end{array}$} & \multicolumn{2}{|c|}{$\begin{array}{r}\text { Hardness } \\
\text { as } \mathrm{CaC}_{1} \\
\end{array}$} & \multirow[b]{2}{*}{$\begin{array}{l}\text { Percent } \\
\text { Sodium }\end{array}$} & \multirow[b]{2}{*}{$\begin{array}{c}\text { Sodium } \\
\text { Absorption } \\
\text { Ratio (SAR) }\end{array}$} & \multirow[b]{2}{*}{$\begin{array}{l}\text { Specific } \\
\text { Conductance } \\
\text { Micromhos } \\
\text { at } 25^{\circ} \mathrm{C}\end{array}$} & \multirow[b]{2}{*}{$\mathrm{pH}$} \\
\hline & & $\begin{array}{c}\text { a- } \\
\text { Calcium } \\
\mathrm{Ca}\end{array}$ & $\begin{array}{c}\text { Magnesium } \\
\mathrm{Mg}\end{array}$ & $\begin{array}{l}\text { Sodium and } \\
\text { Potassium } \\
\mathrm{Na}+\mathrm{K}\end{array}$ & $\begin{array}{c}\text { Bicar- } \\
\text { bonate } \\
\mathrm{HCO}_{3}\end{array}$ & $\begin{array}{c}\text { Sul fate } \\
\mathrm{SO}_{4}\end{array}$ & $\begin{array}{c}\text { Cloride } \\
\mathrm{Cl}\end{array}$ & $\underset{F}{\text { Flouride }}$ & $\begin{array}{c}\mathrm{Ni} \text { trate } \\
\mathrm{NO}_{3} \\
\end{array}$ & $\begin{array}{c}\text { Boron } \\
\text { B }\end{array}$ & $\begin{array}{c}\text { Parts } \\
\text { per } \\
\text { million }\end{array}$ & $\begin{array}{c}\text { Tons } \\
\text { per } \\
\text { Acre- } \\
\text { foot }\end{array}$ & $\begin{array}{c}\text { Calcium } \\
\text { Magnesium }\end{array}$ & $\begin{array}{c}\text { Non- } \\
\text { carbonate }\end{array}$ & & & & \\
\hline 25.18 .8 .242 & 65 & - & - & - & 284 & 1,820 & 65 & - & - & - & - & - & 2,200 & 1,970 & - & - & 3,100 & 6.9 \\
\hline 25.18 .21 .441 & 65 & - & - & - & 254 & 2,020 & 275 & - & - & - & - & - & 2,500 & 2,290 & - & - & 3,080 & 6.9 \\
\hline 25.18 .25 .240 & - & - & - & - & 158 & 719 & 79 & - & - & - & - & - & 940 & 810 & - & - & 1,650 & 7.2 \\
\hline 25.18 .26 .111 & 61 & 556 & 264 & 65 & 202 & 2,230 & 82 & 3.2 & 2.4 & .48 & 3,300 & 4.49 & 2,470 & 2,310 & 5 & .6 & 3,530 & 7.1 \\
\hline 26.18 .21 .223 & 71 & 190 & 77 & 4.4 & 272 & 547 & 15 & 1.1 & $4 . \pm$ & .24 & 981 & 1.33 & 810 & 588 & 1 & .1 & 1,320 & 7.0 \\
\hline 26.18 .21 .411 & 72 & - & - & - & 268 & 563 & 25 & - & • & - & - & - & 850 & 630 & - & - & 1,370 & 7.1 \\
\hline 26.18 .28 .113 & 72 & - & - & - & 265 & 500 & 47 & - & - & - & - & - & 890 & 673 & 0 & 0 & 1,470 & 7.0 \\
\hline 26.18 .29 .113 & 68 & 230 & 92 & 17 & 242 & 672 & 57 & 1.1 & 11 & .05 & 1,200 & 163 & 952 & 754 & 4 & .2 & 1,610 & 7.1 \\
\hline 26.18 .30 .213 & 68 & - & - & - & 207 & 751 & 60 & - & - & - & - & - & 990 & 820 & - & - & 1,700 & 7.0 \\
\hline Do. & 68 & - & - & - & 214 & 749 & 56 & - & - & - & - & - & 1,010 & 834 & - & - & 1,700 & 7.1 \\
\hline 26.18 .30 .321 & 68 & - & - & - & 213 & - & 76 & - & - & - & - & - & 1,060 & 806 & - & - & 1,800 & 7.1 \\
\hline
\end{tabular}




\begin{tabular}{|c|c|c|}
\hline $\begin{array}{l}\text { Document Control } \\
\text { Page }\end{array}$ & \begin{tabular}{|l|l} 
2. NTIS Accession No. \\
DE89009511
\end{tabular} & 3. Recipient's Accession No. \\
\hline \multirow{2}{*}{\multicolumn{2}{|c|}{$\begin{array}{l}\text { 4. Title and Subtitie Evaluation of Available Saline Water } \\
\text { Resources in New Mexico for the Production of } \\
\text { Microalgae }\end{array}$}} & $\begin{array}{l}\text { 5. Publication Date } \\
\text { August } 1990\end{array}$ \\
\hline & & $\overline{6 .}$ \\
\hline 7. Author(s) Lansford, & J. Hernandez, P. Enis, D. Truby, C. Mapel & 8. Perlorming Organization Rept. No. \\
\hline \multicolumn{2}{|c|}{$\begin{array}{l}\text { 9. Performing Organization Name and Address } \\
\text { New Mexico State University, Department of Agricultura } \\
\text { Economics and Agricultural Business } \\
\text { Box } 3169 \\
\text { Las Cruces, NM } 88003\end{array}$} & $\begin{array}{l}\text { 11. Contract (C) or Grant (G) No. } \\
\text { (C) } \\
\text { (G) }\end{array}$ \\
\hline \multirow{2}{*}{\multicolumn{2}{|c|}{$\begin{array}{l}\text { 12. Sponsoring Organization Name and Address } \\
\text { Solar Energy Research Institute } \\
1617 \text { Cole Boulevard } \\
\text { Golden, Colorado } 80401-3393\end{array}$}} & $\begin{array}{l}\text { 13. Type ol Report \& Period Covered } \\
\text { Technical }\end{array}$ \\
\hline & & 14. \\
\hline \multicolumn{3}{|l|}{ 15. Supplementany Noles } \\
\hline \multicolumn{3}{|c|}{$\begin{array}{l}\text { 16. Abstract (Limit: } 200 \text { words) } \\
\text { Researchers evaluated saline water resources in New Mexico for their suitability } \\
\text { as sites for large-scale microalgae production facilities. Production of micro- } \\
\text { algae could provide a renewable source of fuel, chemicals, and food. In addition, } \\
\text { making use of the unused saline water resources would increase the economic } \\
\text { activity in the state. } \\
\text { After analyzing the } 15 \text { billion acre-ft of unused saline water resources in the } \\
\text { state, scientists narrowed the locations down to six sites with the most potential } \\
\text { With further analysis, they chose the Tularosa Basin in southern New Mexico as } \\
\text { the best-suited area for a 1000-hectare microalgae production facility. }\end{array}$} \\
\hline \multirow{2}{*}{\multicolumn{3}{|c|}{$\begin{array}{l}\text { 17. Document Analysis } \\
\text { a. Descriptors } \\
\text { renewable energy, Iiquid fuels, saline water, microalgae production } \\
\text { b. Identifiers/Open-Ended Terms }\end{array}$}} \\
\hline & & \\
\hline \multirow{3}{*}{\multicolumn{2}{|c|}{$\begin{array}{l}\text { 18. Availability Statement } \\
\text { National Technical Information Service } \\
\text { U.S. Department of Commerce } \\
5285 \text { Port Royal Road } \\
\text { Springfield, Virginia } 22161\end{array}$}} & 19. No. of Pages \\
\hline & & 92 \\
\hline & & $\begin{array}{l}\text { 20. Price } \\
\\
\text { A05 }\end{array}$ \\
\hline
\end{tabular}

